\title{
NÓDULO TIROIDEO Y CÁNCER \\ DIFERENCIADO DE TIROIDES
}

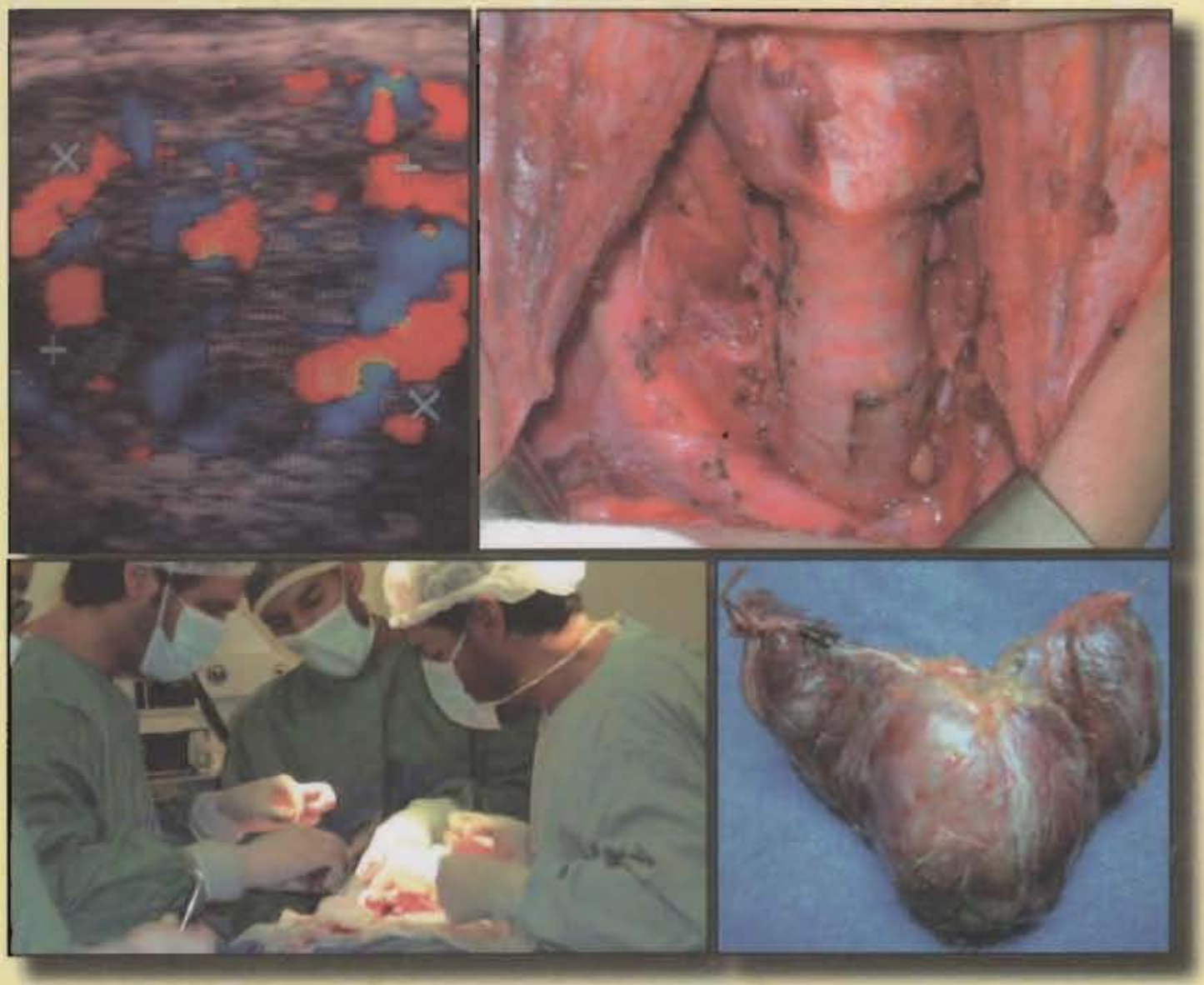

Luis Cimarra

Edgardo Berriel

Relato oficial

65 Congreso Uruguayo de Cirugía 


\title{
Nódulo Tiroideo y Cáncer Diferenciado de Tiroides
}

\author{
Relato Oficial \\ 65o Congreso Uruguayo de Cirugía \\ Montevideo
}

Autor: Luis Cimarra

Co Autor: Edgardo Berriel 
Diseño y diagramación del interior: Patricia Carretto

E-mail: paticarretto@adinet.com.uy

Se terminó de imprimir en el mes de octubre de 2014

Hecho el depósito que marca la ley.

Todos los derechos reservados. Queda prohibida la reproducción parcial o

total de cualquier medio gráfico o informático sin previa autorización del editor. 


\title{
Índice
}

\author{
Primera Parte \\ Dr. Luis Cimarra
}

\section{Capítulo I}

Nódulo Tiroideo
la) Definición
Ib) Epidemiología e Historia Natural
Ic) El nódulo tiroideo como problema clínico
Id) Métodos de estudio
le) Estrategia diagnóstica - Indicaciones de la PAAF
If) Interpretación del informe citológico y conducta a seguir
Ig) Resumen de estrategia diagnóstica en el nódulo tiroideo
Ih) Indicaciones de cirugía en el Nódulo Tiroideo

\section{Capítulo II}

Introducción al Cáncer de Tiroides
Ila) Epidemiología y clasificación
IIb) Cáncer Diferenciado de Tiroides

Capítulo III

El problema del microcarcinoma

IIla) Definición, generalidades, alcance

IIIb) Microcarcinoma papilar de tiroides 
Capítulo IV

Cáncer de Tiroides y Bocio Multinodular.

IVa) Delimitación del tema

IVb) Aspectos epidemiológicos

IVc) Posibilidades diagnósticas

IVd) Implicancias pronósticas y terapéuticas

Bibliografía

\section{Segunda Parte}

TRATAMIENTO

\section{Dr. Edgardo Berriel}

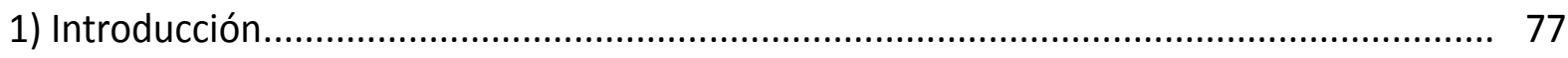

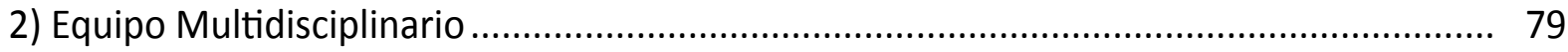

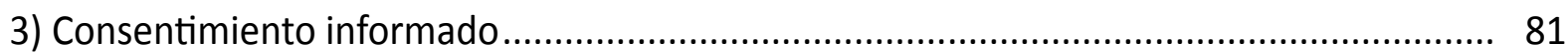

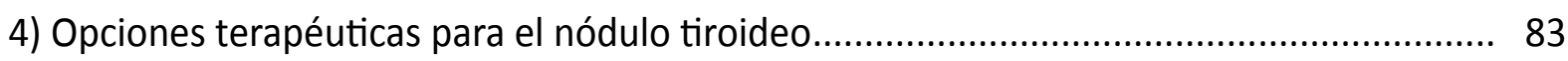
a) Control evolutivo
b) Hormonoterapia supresiva
c) Radio-iodo
d) Ablación no resectiva
e) Cirugía

5) Opciones terapéuticas para el cáncer diferenciado de tiroides
a) Tratamiento no quirúrgico inicial
b) Tratamiento ablativo no quirúrgico
c) Tratamiento quirúrgico

6) Bibliografía

Tablas y figuras 


\title{
Primera Parte
}

\author{
Dr. Luis Cimarra
}




\section{Capítulo I}

\section{Nódulo Tiroideo}

\section{la) Definición}

Resulta difícil establecer una definición precisa de nódulo tiroideo (NT) por cuanto éste no constituye una entidad nosológica o anátomo-patológica específica, en la medida en que prácticamente cualquier enfermedad tiroidea puede presentarse bajo forma de uno o mas NT. Asumiendo que la anatomía normal de la glándula tiroides es la de un parénquima homogéneo, puede definirse al nódulo tiroideo como una estructura anatómica "anormal" y focal, de forma habitualmente redondeada u oval, única o múltiple, localizada en la glándula tiroides. La denominación "nódulo tiroideo" es por lo tanto necesariamente una denominación provisoria hasta tanto se logre obtener una confirmación anátomo-patológica definitiva de la naturaleza de la lesión. Mas aún, considerando la forma en que es diagnosticado habitualmente el NT puede catalogarse al mismo como una suerte de "entidad clínico-imagenológica provisoria" $(1,2)$

La forma de presentación de los NT puede ser muy variada, yendo desde el nódulo único no palpable descubierto incidentalmente por imagenología o "incidentaloma", pasando al nódulo único palpable, a los nódulos múltiples no palpables y palpables y finalmente en progresión ascendente en cuanto al número de nódulos a las glándulas tiroideas verdaderamente multinodulares. La afectación extensa y bilateral por nódulos puede configurar o no un diagnóstico de Bocio Multinodular, lo cual dependerá fundamentalmente del volumen glandular total y de la presencia o no de autonomía de crecimiento en los nódulos(1).

Cualquier enfermedad tiroidea puede adoptar total o parcialmente una forma nodular, ya sea a nódulo único o bien múltiples, por lo cual la amplia definición de NT engloba a nódulos con disímil composición y significado biológico $(1,2,3,4)$ :

\section{Nódulos benignos (95\%):}

- Coloide: Predomina el componente coloide sobre el epitelial

- Hiperplásico: Predomina el componente epitelial sobre el coloide

- Adenoma: El componente epitelial constituye una verdadera neoplasia benigna 
- Quístico: Predomina el componente líquido

- Tiroiditis: Linfocitaria, subaguda, granulomatosa, e incluso aguda(absceso)

- Otros (raros): Parásitos, amiloidosis,etc

\section{Nódulos malignos (5\%):}

- Carcinoma papilar

- Carcinoma folicular

- Carcinoma de células de Hürthle

- Carcinoma pobremente diferenciado

- Carcinoma medular

- Carcinoma anaplásico

- Metástasis tiroideas de otros tumores

Los nódulos benignos son mucho mas frecuentes que los malignos, y dentro de los benignos predominan ampliamente los nódulos coloides, es decir nódulos que poseen solo una pequeña proporción de células tiroideas o "componente epitelial" $(3,4)$.

\section{Ib) Epidemiología e Historia Natural}

La prevalencia de los NT se incrementa con la edad, el sexo femenino y la procedencia de áreas territoriales con deficiencia endémica de yodo. Son extremadamente comunes en la práctica clínica actual. Su prevalencia basada exclusivamente en la palpación cervical considerando ambos sexos oscila en un $3-7 \%$, con un incremento de aproximadamente $1 \%$ por cada década de la vida; la prevalencia en mujeres es aproximadamente el triple que en hombres. Debe considerarse que practicamente el $50 \%$ de las personas que se presentan con un único nódulo palpable en realidad tienen otros NT inaparentes que se detectan posteriormente por métodos de imagen, especialmente la ultrasonografía. La prevalencia en tiroides de estudios de autopsia de personas fallecidas sin historial de enfermedad tiroidea es de $30-60 \%(3,4,5)$.

Sin embargo, el mayor impacto contemporáneo en la detección de NT clínicamente inaparentes o "incidentales" lo ha generado la Ultrasonografía Tiroidea (UT). En efecto, en los últimos 20 años el desarrollo tecnológico de ecógrafos de alta resolución, sumado a una cada vez mayor accesibilidad del estudio ecográfico para la población en general, ha generado una verdadera "epidemia" de diagnóstico de nódulos tan pequeños como solo 1-2 mms (6). La prevalencia de nódulos tiroideos detectados por UT oscila entre $30-70 \%$, con variaciones dependientes de la ingesta de yodo de la población estudiada, sexo, edad, etc. Puede considerarse esquemáticamente que al menos en el $50 \%$ 
de cualquier población humana a la que se le practique una UT se detectarán uno o mas nódulos tiroideos $(1,2,3,4,5,6)$.

A esto debe agregarse la frecuente detección de NT incidentales en estudios imagenológicos diversos tales como la Tomografía Axial Computarizada (TAC), Resonancia Nuclear Magnética (RNM), Eco-Doppler de Arterias Carótidas e incluso en la Tomografía de Emisión de Positrones o PET-SCAN, todos ellos solicitados por razones diversas no vinculadas a enfermedad tiroidea. La constatación de uno o mas nódulos tiroideos va seguida casi invariablemente de la remisión del paciente al endocrinólogo o al cirujano, desde donde surge lógicamente una indicación adicional de UT (6). Un estudio realizado por Nilsson y col sobre 3641 pacientes a quienes se les practicó un PET-SCAN con Flúordesoxiglucosa (FDG) evidenció una captación tiroidea focal o nódulo tiroideo en el 1\% de los casos, 37 pacientes en total, de los cuales el $43 \%$ demostró posteriormente ser portador de una neoplasia maligna tiroidea primitiva o secundaria (7).

Historia natural de los nódulos tiroideos: Es evidente que la historia natural de una entidad provisoria dependerá en última instancia de la naturaleza anátomo-patológica definitiva del nódulo o nódulos en cuestión. No obstante, como epidemiológicamente predominan netamente las causas benignas del NT se pueden manejar algunos datos de utilidad práctica. En áreas con buena ingesta de yodo la mayoría de los NT permanecen incambiados durante muchos años, incluso no es infrecuente que muchos de ellos disminuyan de volumen o bien desaparezcan completamente. Se han reportado tasas de regresión espontánea completa de NT de entre $22-46 \%$ en plazos de seguimiento que van desde los 6 meses a 3 años. Menos del 20\% de los NT considerados en su conjunto muestran tendencia al crecimiento progresivo, pero en estos casos la probabilidad de hallazgo de malignidad se eleva hasta cerca del $30 \%$, aunque también es indicativo de que un alto porcentaje de los NT benignos crecen durante su seguimiento $(3,4)$. Cuando los nódulos tiroideos configuran un diagnóstico claro de Bocio Multinodular (BMN), donde la autonomía de crecimiento de muchos de los nódulos es la regla, entonces la historia natural será la del lento pero sostenido y progresivo crecimiento (8).

\section{Ic) El nódulo tiroideo como problema clínico}

Como ya fue explicado el uso extensivo de la UT ha generado en los últimos años una verdadera epidemia de diagnóstico de NT clínicamente inaparentes $(5,6)$. Ademas del incremento de costos por la proliferación de estudios de UT, las consecuencias del hallazgo de tal volumen de NT han tenido repercusiones aún mas dramáticas sobre los sistemas asistenciales.

En un interesante estudio multiinstitucional realizado en los EEUU se revisó el período de 5 años comprendido entre 2006 -2011, contabilizando el volumen de procedimientos sobre la tiroides realizados en dicho lapso en forma comparativa al de los años previos. De acuerdo a este estudio las consecuencias de la proliferación de UT practicadas en ese período fueron las siguientes (9):

- Un aumento a mas del doble en el número total de Punciones Aspiraciones con Aguja Fina (PAAF) durante el período señalado, con una tasa de incremento anual de $16 \%$.

- Un incremento total de $31 \%$ en el número de operaciones practicadas por NT. 
- Una tasa de incremento anual en el número de Tiroidectomías Totales (TT) de $12 \%$, con un porcentaje total de TT de $51 \%$ y de lobectomías de $41 \%$.

- El porcentaje de TT por neoplasias tiroideas benignas y malignas en su conjunto fue de mas de la mitad (56\%)

El incremento del diagnóstico de Cáncer de Tiroides (CT) en el período del estudio fue de 59\%, pasando de unos 30.000 casos a 48.000 casos al año en los EEUU, según datos obtenidos de la American Cancer Society (ACS) (9).

Si se toma en cuenta el período de 12 años entre 2001 - 2013 la incidencia de CT se triplicó en los EEUU, pasando de 20.000 casos al año a unos 60.000, es decir un 209\% de incremento. En contraste con este gran aumento en el diagnóstico de nuevos casos la tasa de mortalidad relacionada al CT solo se incrementó un $16 \%$ en total (9).

El mayor porcentaje de incremento en los casos de CT en los EEUU se debe fundamentalmente al gran aumento en la detección de casos de microcarcinoma papilar de tiroides (micro CPT), diagnosticados en nódulos clínicamente inaparentes detectados por UT u otros métodos de imagen. Este incremento en el diagnóstico de micro CPT es consecuencia directa del uso extensivo de la UT y del incremento subsiguiente del diagnóstico de NT clínicamente inaparentes, algunos de los cuales corresponden a micro CPT. Esta situación ha generado un problema significativo y aún no totalmente dilucidado acerca de cómo debe encararse el tratamiento de estos pequeños cánceres, que si bien en la gran mayoría de los casos tienen un excelente pronóstico, también surgen en ocasiones como tumores con potencial agresividad (10). La estrategia en el manejo de estas lesiones se discute mas adelante.

En suma, es evidente que el sobrediagnóstico de NT conlleva también un aumento en el número de PAAF sobre la tiroides, un incremento en el número de operaciones tiroideas, una mayor agresividad en la extensión de la resección glandular, un incremento en la incidencia de cánceres tiroideos, especialmente micro CPT, y genera un área de incertidumbre en cuanto a como debe encararse a futuro esta verdadera "epidemia" contemporánea.

Adicionalmente, la baja prevalencia de cáncer de tiroides en nódulos palpables (menor a 5\% o aún menos) contrasta con la alta prevalencia de hallazgo de micro CPT en estudios de autopsia y en piezas de tiroidectomía resecadas por patología benigna, que oscilan promedial y respectivamente en 17 y $13 \%$. Si se estima por ejemplo que como mínimo el $20 \%$ de la población tiene multinodularidad en la tiroides, y que 5\% de la misma tiene un CT en alguno de esos nódulos, esto debería representar una prevalencia de CT en la población general de unos 1000 casos / 100.000 habitantes. Sin embargo, la prevalencia de cánceres clínicamente relevantes es de solo alrededor de 5 casos / 100.000 hab / año, lo cual es altamente sugestivo de que solo 1 de cada 200 microcarcinomas adquiere relevancia clínica y llega a diagnosticarse (3). 


\section{Id) Métodos de estudio}

Para el estudio del o los NT disponemos de los siguientes recursos:

- Evaluación Clínica (EC)

- Ultrasonografía Tiroidea (UT)

- Citología por Punción - Aspiración con Aguja Fina (PAAF)

- Evaluación funcional: TSH y Gammagrafía

- Otros métodos de imagen: Tomografía Axial Computarizada (TAC), Resonancia Nuclear Magnética (RNM) y Tomografía de Emisión de Positrones (PET-SCAN)

\section{Evaluación Clínica}

Siguiendo criterios basados exclusivamente en la historia clinica y en el examen físico del paciente se pueden extraer valiosos datos que pueden incidir notablemente en la toma de decisiones una vez que se dispone de los exámenes paraclínicos, especialmente cuando éstos no son concluyentes. Se describen a continuación $(1,2,3,5,11,12)$.

Cuando se obtiene la historia clínica del paciente debe tenerse en cuenta que cualquier enfermedad tiroidea tanto benigna como maligna puede ser causa de nódulos tiroideos, los cuales la mayor parte de las veces son asintomáticos. Es bastante común que los nódulos permanezcan incambiados o bien creciendo en forma sutil e inaparente durante muchos años, por lo cual también es muy común, como ya se explicó, que sean descubiertos en forma incidental ya sea a través del examen físico del cuello o bien por medio de estudios de imagen solicitados por causas diversas no relacionadas con la tiroides. Menos frecuentemente los nódulos son causa de síntomas cervicales tales como tumoración visible y/o palpable, dolor, disfonía o bien aparición concomitante de ganglios linfáticos regionales, todos ellos de gran valor diagnóstico.

También debe tenerse en cuenta que es relativamente frecuente que síntomas diversos a nivel cervical o de la esfera otorrinolaringológica sean atribuídos por el paciente a dolencias tiroideas, especialmente si ya sabe que es portador de algún nódulo tiroideo.

Los antecedentes personales de exposición a radiación, sobre todo en la niñez y adolescencia, son especialmente importantes, tanto por irradiación terapeútica (radioterapia externa, Yodo 131 terapeútico, etc) como por exposición a contaminación rádica ambiental (accidentes nucleares, explosiones atómicas, etc).

Dentro de los antecedentes ambientales y familiares interesa consignar especialmente la procedencia de áreas de déficit endémico de yodo, antecedentes de historia familiar de enfermedad tiroidea benigna y finalmente historia familiar de cáncer de tiroides, especialmente Carcinoma Medular Familiar, Cáncer Medular en relación a Neoplasias Endócrinas Múltiples y mas raramente Carcinoma Papilar Familiar. 
El examen físico completo y especialmente el examen cervical y de los territorios ganglionares centrales y laterales del cuello es fundamental.

Una vez recabados todos los datos clínicos debe evaluarse fundamentalmente cuáles de ellos son sugestivos de baja probabilidad de malignidad y cuáles tiene una alta probabilidad de malignidad en el o los NT en cuestión.

\section{Datos clínicos que sugieren baja probabilidad de malignidad:}

- Historia familiar de enfermedad tiroidea autoinmune (Hashimoto, Graves)

- Historia familiar de nódulos tiroideos benignos o bocio en general

- Presencia de disfunción tiroidea

- Bocio difuso o multinodular conocido

- Crecimiento explosivo, horas o días (hemorragia en nódulo benigno)

- Dolor exquisito a nivel del nódulo

- Nódulo blando, liso y móvil

- Nódulos múltiples palpables

\section{Datos clínicos que sugieren mayor probabilidad de malignidad:}

- Historia familiar de cáncer de tiroides

- Exposición a radiaciones en infancia o adolescencia ( 20 - 50\% riesgo de malignidad)

- Edad menor de 20 o mayor a 70 años

- Sexo masculino (doble incidencia de malignidad)

- Disfagia y/o disfonía en ausencia de bocio evidente

- Rápido crecimiento (meses)

- Nódulo sólido, duro y fijo (frecuente en el Carcinoma Papilar)

- Tamaño mayor a $3 \mathrm{cms}$ (>0 = a $4 \mathrm{cms}$ tiene $30 \%$ de malignidad)

- Presencia de adenopatías palpables

\section{Ultrasonografía tiroidea}

La moderna Ultrasonografía Tiroidea (UT), utilizando scanners de alta resolución operados en tiempo real con altas frecuencias, del orden de 7-20 MHz, y en combinación con el Doppler Color o mejor aún con el Power Angio, han revolucionado el diagnóstico de las enfermedades tiroideas. Las altas frecuencias son las ideales para tejidos blandos y órganos relativamente superficiales como la tiroides, donde dan imágenes de alta resolución, en tanto que órganos profundos como el páncreas requieren del uso de bajas frecuencias y proporcionan por lo tanto una menor resolución. El Doppler 
Color o el Power Angio, incorporados en el mismo equipo son superpuestos a la imagen ecográfica en pantalla y aportan interesantes datos acerca de la vascularización glandular y de los nódulos tiroideos, datos que pueden influír notablemente en la toma de decisiones, tales como indicar una PAAF o incluso una cirugía. Esta combinación de técnicas, actualmente de rutina en el estudio de las enfermedades tiroideas, ha sido denominada genéricamente Ecografía - Doppler Color (EDC) o bien Ecografía - Power Angio (EPA) según cual de las dos técnicas de estudio vascular se utilicen.

Se analizan a continuación las principales características y utilidades de la Ecografía en combinación con el Doppler Color (EDC) o el Power Angio (EPA) en el estudio de los nódulos tiroideos $(13,14,15,16,17,18)$.

\section{La UT (EDC y EPA) permite obtener los siguientes datos en el estudio de la tiroides:}

- Localización de la glándula y sus relaciones con las estructuras vecinas

- Medida de los diámetros de los lóbulos e istmo y cálculo del volumen glandular total

- Aspecto ecográfico del parénquima, homogéneo o bien irregular

- Presencia de áreas o "nódulos" glandulares sólidos, quísticos o mixtos, su tamaño, bordes, grado de ecogenicidad y presencia de microcalcificaciones.

- Tipo de vascularización glandular y de los nódulos

- Presencia de ganglios linfáticos regionales patológicos

- Permite también guiar la PAAF

La glándula tiroides normalmente se localiza por delante del eje visceral del cuello al cual abraza, teniendo a los lados a ambos paquetes yúgulo-carotídeos, y por delante los músculos infrahioideos en el sector medio y lateralmente ambos músculos esterno - cleido - mastoideos. El corte ecográfico transversal es el que mejor evidencia las relaciones de la glándula con los órganos y estructuras vecinas.

Las dimensiones de la tiroides son variables, pero interesa consignar que las medidas máximas normales que se aceptan para los lóbulos son $50 \times 20 \times 20 \mathrm{mms}$ para altura, ancho y espesor lobares respectivamente. El volumen glandular se calcula multiplicando estas medidas entre sí y luego por la constante 0,52 . De acuerdo a esto el volumen máximo normal que puede aceptarse para un lóbulo tiroideo es de 10,4 cm3 o ml. Simplificando cálculos puede aceptarse que un volumen máximo normal admisible para la tiroides sería de unos $20 \mathrm{~cm} 3$.

El aspecto ecográfico "normal" de la glándula es teóricamente homogéneo, pero esto contrasta con una realidad indiscutible de que en el $50-70 \%$ de las ecografías cervicales aparecen NT incidentales. Como la gran mayoría de estos NT son pequeños y benignos parecería razonable aceptar que la presencia de estos NT banales deben ser considerados dentro de la "normalidad" de hallazgos ecográficos. 
Con respecto a los nódulos propiamente dichos la ecografía es capaz de detectarlos en tamaños tan pequeños como solo $1-2 \mathrm{mms}$. Solo menos del $5 \%$ de los nódulos tiroideos son verdaderos quistes de paredes finas, por lo cual el $95 \%$ son nódulos sólidos (70\%) o mixtos (25\%). El riesgo de malignidad en los quistes de paredes finas es prácticamente de cero, mientras que tanto los nódulos sólidos como aquellos mixtos tienen estadísticamente una probabilidad de malignidad similar. Los quistes simples suelen ser congénitos, en tanto que los nódulos mixtos son en realidad nódulos sólidos parcialmente quistificados, debido a hemorragia y/o necrosis parcial, hechos frecuentes en los nódulos benignos pero que también pueden darse en los Carcinomas Papilares fundamentalmente (19). La ecogenicidad de los nódulos también es importante, dado que alrededor del $90 \%$ de los cánceres son hipoecogénicos, sin embargo el 50-60\% de los nódulos benignos también son hipoecogénicos. Los nódulos hiperecoicos raramente son malignos, menos del $1 \%$. La hipoecogenicidad es por lo tanto de alta sensibilidad para la detección de malignidad, pero muy poco específica. Los nódulos de márgenes bien definidos y rodeados de un halo ecogénico son mas frecuentemente benignos, ya que indican un crecimiento expansivo que comprime el tejido vecino. Márgenes irregulares y contornos infiltrativos son característicos de los nódulos malignos. La presencia de microcalcificaciones en los NT en general son indicativas de malignidad por lo menos en un $30 \%$ de los casos, especialmente Carcinoma Papilar y Carcinoma Medular, en tanto que las macrocalcificaciones son inespecíficas. Un NT solitario con microcalcificaciones es maligno en el 50\% de los casos (20).

La vascularización de la glándula y de los nódulos, estudiada mediante doppler color o power angio aporta datos muy importantes. La hipervascularización generalizada del parénquima tiroideo es característica del hipotiroidismo, indicando indirectamente una sobreestimulación glandular por altos niveles de TSH. La hipervascularización extrema difusa de la tiroides o "infierno tiroideo" es característica de la enfermedad de Graves, en tanto que focalizada a uno o mas nódulos sugiere adenoma o BMN tóxico según sea el caso. En condiciones de eutiroidismo la vascularización de los nódulos tiroideos tiene importantes implicancias en la presunción de malignidad. Messina (21) clasifica la vascularización de los NT en 4 tipos:

- Tipo I: Nódulo sin vascularización central ni periférica

- Tipo II: Vascularización periférica o perinodular

- Tipo III: Vascularización central aumentada o "neovascularización" central

- Tipo IV: Vascularización central muy aumentada o"infierno tiroideo"

Los tipo I y II son los patrones predominantes en los nódulos benignos eufuncionantes. El tipo IV es característico de los nódulos hiperfuncionantes del hipertiroidismo. El tipo III es mas frecuente en los nódulos neoplásicos, especialmente en los malignos, como expresión de la neovascularización del tumor, aunque también puede verse en adenomas y nódulos hiperplásicos. El patrón de tipo III se muestra por lo tanto con una aceptable sensibilidad pero una baja especificidad.

La identificación de adenomegalias regionales, ya sea en el compartimento central del cuello (peritiroideas) o lateral (yúgulo-carotídeas y/o supraclaviculares) indican alta probabilidad de malignidad, especialmente si se ha detectado un NT con caracteres de sospecha propios. 
La guía ecográfica para la PAAF es fundamental para mejorar el rendimiento diagnóstico de la citología, por cuanto permite puncionar selectivamente solo aquellos nódulos de riesgo, palpables o no palpables, y en el caso de los nódulos mixtos puncionar selectivamente el componente sólido de estos nódulos. En el momento actual se considera imprescindible la guía ecográfica cuando se decide realizar una PAAF, prácticamente en forma sistemática.

\section{Resumen de las características ecográficas de los NT sugestivas de benignidad:}

- Nódulo completamente quístico de paredes finas

- Isoecogénico con el parénquima tiroideo circundante o bien hiperecogénico

- Contornos bien delimitados

- Halo ecogénico de compresión perinodular

- Sin microcalcificaciones

- Limitado dentro de la cápsula tiroidea

- Sin vascularización, con vascularización solo periférica o bien con "escasos vasos centrales"

- Sin adenomegalias satélites

\section{Resumen de las características ecográficas de los NT que sugieren malignidad:}

- Nódulo hipoecogénico

- Sin halo ecogénico perinodular

- Contornos mal delimitados o bien claramente infiltrativos

- Evasión extratiroidea de cualquier tipo

- Presencia de microcalcificaciones

- Neovascularización central o tipo III

\section{Citología por punción aspiración con aguja fina (PAAF)}

La punción aspiración con aguja fina (PAAF) de las diferentes lesiones tiroideas, especialmente de los nódulos tiroideos, constituye junto con la UT uno de los pilares fundamentales en el diagnóstico paraclínico de las mismas. El método consiste en la punción del o los nódulos con una aguja № 23, cuyo diámetro exterior es de solo $0,6 \mathrm{mms}$, obteniendo luego por aspiración con jeringa u otro dispositivo similar material celular y fluídos desde el nódulo. Se obtiene mayor rendimiento diagnóstico cuando la PAAF es realizada con guía ecográfica. Este material es posteriormente transformado en un frotis sobre una lámina portaobjetos, donde es secado, fijado y coloreado con técnicas del tipo May Grundwald Giemsa o semejantes para ser examinado al microscopio óptico $(5,22,23,24)$. 
Una vez examinado el frotis corresponde en primer lugar establecer descriptivamente en cual de las 4 categorías diagnósticas mayores puede clasificarse el citograma de acuerdo a los componentes que se observan al microscopio $(22,25)$ :

- Predominio coloide

- Predominio epitelial

- Quistificación

- Inflamatorio y/o linfoma

En el citograma coloide se observa una predominancia neta de coloide, una sustancia proteínica que contiene tiroglobulina y hormona tiroidea, que es producida por las células foliculares tiroideas, es decir por el componente epitelial. La presencia de abundante coloide en un citograma es habitualmente indicativo de una lesión benigna, fundamentalmente nódulos adenomatosos y coloides de hiperplasia-involución. El componente epitelial suele ser escaso y con el aspecto de "células tiroideas pequeñas".

Un citograma de predominio epitelial es también conocido como citograma "parenquimatoso", "folicular", o de "células tiroideas medianas", con un componente coloide menor. En esta categoría entran una diversidad de enfermedades benignas y malignas de la tiroides:

- Nódulo hiperplásico común y nódulo hiperplásico de células de Hürthle

- Adenoma folicular y adenoma de células de Hürthle

- Carcinoma diferenciado de tiroides: Papilar, Folicular y de Hürthle

- Otros carcinomas: Pobremente diferenciado, Medular, Anaplásico, otros.

Un citograma de quistificación esta constituído habitualmente por abundante líquido, células "espumosas" y grandes macrófagos, y un componente epitelial escaso. La mayor parte de estas lesiones corresponden a degeneración quística de nódulos adenomatosos benignos, pero también debe excluírse la presencia de Carcinoma Papilar (CPT) en el componente epitelial de estos quistes. No son infrecuentes los cambios quísticos en los CPT ni tampoco en sus metástasis ganglionares.

En el citograma inflamatorio $y / o$ del linfoma tiroideo se encuentra un claro predominio de células inflamatorias, fundamentalmente linfocitos, y el rango de diagnósticos pude ir desde la Tiroiditis Linfocitaria Crónica (Hashimoto), Tiroiditis Subaguda de De Quervain, Tiroiditis Granulomatosa de Riedel, hasta el Linfoma Tiroideo, donde existe una proliferación de linfocitos atípicos que infiltra una glándula usualmente afectada previamente por una Tiroiditis de Hashimoto. En casos mucho menos frecuentes la tiroiditis puede ser focal y aguda, hasta con supuración, predominando entonces los polimorfonucleres, piocitos y bacterias.

La citología descriptiva, tal como la hemos esquematizado carece por si misma de utilidad en la toma de decisiones, por cuanto el citólogo solo describe lo que ve pero no aventura diagnóstico presuntivo. La moderna citología exige al técnico una interpretación cada vez mas afinada y exigente de 
lo que observa y una conclusión final, que le permita elaborar distintas categorías diagnósticas que el cirujano pueda utilizar, junto a otros elementos, en el proceso de selección de cuales pacientes deben ser operados y cuales pueden ser solo observados.

En este sentido el 22 y 23 / octubre / 2007 tuvo lugar en Bethesda - Maryland - Estados Unidos el Congreso "The Nacional Cancer Institute. Thyroid Fine Needle Aspiration. State of the Science Conference" organizado por el Instituto Nacional del Cancer de los EEUU. De este evento surge la moderna clasificación de los informes citológicos en 6 categorías, también conocida simplemente como la "Clasificación Bethesda" que ha sido adoptada universalmente, permitiendo la unificación de criterios y mejorando el rendimiento diagnóstico de la Citología $(26,27)$. La interpretación detallada de la clasificación y su uso en la toma de decisiones en el encare terapéutico del NT se consideran con especial detalle mas adelante, por lo cual aquí solo presentamos la clasificación sin mayores comentarios.

\section{Clasificación Bethesda 2007:}

- Cat I: Muestra no diagnóstica o insatisfactoria

- Cat II: Resultado benigno

- Cat III: Atipía folicular de significado incierto

- Cat IV: Neoplasia folicular o presunta neoplasia folicular

- Cat V: Diagnóstico presuntivo de cáncer

- Cat VI: Resultado maligno

\section{Evaluación funcional. TSH y Gammagrafía:}

\section{Dosificación de TSH}

Para la evaluación funcional de un paciente en estudio por NT, es decir en principio un paciente con baja sospecha de disfunción tiroidea, el estudio fundamental es la dosificación de TSH ultrasensible, sumamente sensible para la detección de disfunción tiroidea inaparente o subclínica. Si existe firme sospecha clínica de disfunción tiroidea se solicita de entrada dosificación de TSH y T4 libre. Pequeñas variaciones en mas de la TSH son indicativas de hipotiroidismo subclínico, en tanto que pequeñas variaciones en menos sugieren hipertiroidismo subclínico (22).

\section{Gammagrafía Tiroidea}

La Gammagrafía Tiroidea (CT) se fundamenta en la administración y posterior captación funcional "fisiológica" de un radioisótopo por parte de la tiroides, luego de lo cual la sustancia concentrada en la glándula emite radiación gamma que se transforma en imágenes con el uso de una gammacámara. El isótopo mas utilizado con fines diagnósticos es el Tecnecio 99 (Pertecneciato de Sodio), que se capta en forma similar al yodo pero se elimina mas rápido, con escasa irradiación sistémica del paciente. La dosis habitual es de 5-10 Milicuries (Mci). El yodo 131 (I131) se reserva fundamental- 
mente para el diagnóstico de las recidivas o persistencias del cáncer diferenciado de tiroides o bien con fines terapéuticos ablativos $(22,28)$.

Como estudio morfológico la GT proporciona imágenes planares de baja calidad, muy inferiores a las proporcionadas por la UT. En condiciones de eutiroidismo, que son las habituales en el estudio de los NT, la GT aporta datos acerca de la captación de los nódulos y de la glándula que usualmente carecen de interés práctico para la toma de decisiones en cuanto a la práctica de la PAAF y/o de la propia indicación quirúrgica. Ademas claramente carece de utilidad en el diagnóstico de malignidad. Salvo en el caso de nódulos calientes con supresión del resto de la captación glandular, que solo muy excepcionalmente pueden ser malignos, en el resto de los casos la condición de nódulo tibio o frío carece de sensibilidad y/o especificidad adecuadas para el diagnóstico de malignidad. En algunos casos de NT estudiados por UT y PAAF donde existen dudas para su indicación quirúrgica final la GT podría eventualmente evitar la cirugía en caso de nódulo "caliente", actuando como una suerte de tamizaje final. Sin embargo, la única indicación clara de GT es en aquellos casos de hipertiroidismo causado por nódulos autónomos (adenoma o BMN tóxico), donde al cirujano le interesa identificar la o las áreas responsables para asegurarse de su correcta resección en caso de tiroidectomía menor que total $(22,28)$.

\section{Otros métodos de imagen: TAC, RNM, PET-SCAN:}

\section{TAC y RNM}

La TAC y la RNM solicitadas por diversas causas son una de las formas relativamente frecuentes de hallazgo de NT incidentales en la práctica médica en general, aunque su sensibilidad para la identificación de los mismos es claramente inferior a la de la UT. Ni la TAC ni la RNM tienen por lo tanto aplicación significativa en el encare diagnóstico del NT en general. No obstante, estas técnicas cobran un papel preponderante en el estudio de la extensión lesional del cáncer de tiroides, especialmente cuando se sospecha evasión extratiroidea, compromiso de órganos vecinos, metástasis ganglionares y/o sistémicas. También pueden tener indicación en la etapa diagnóstica de los BMN voluminosos, especialmente si hay componente sumergido $(22,23,28)$.

\section{PET-SCAN}

Al igual que sucede con los anteriores, el PET-SCAN utilizado con diversas intencionalidades diagnósticas es una de las formas contemporáneas de detección de NT incidentales, con la particularidad de que los nódulos detectados por esta técnica tienen una elevada incidencia de malignidad (7). Existen pocos datos que justifiquen recurrir a esta técnica para las etapas diagnósticas de los NT, siendo un método de alto costo, baja disponibilidad y con utilidades mucho mas importantes en la Oncología en general, incluso en el cáncer de tiroides en etapas avanzadas. En general no se recomienda su uso en la evaluación de los NT $(23,28,29)$. Sin perjuicio de lo anterior existe alguna experiencia clínica que parece sugerir que el uso del PET-SCAN en aquellos casos de NT mayores a 2 cms, con citología de neoplasia folicular no Hürthle, permitiría reducir tiroidectomías innecesarias (nódulo finalmente benigno) en un 13-25\% de estos casos específicos (30). 


\section{le) Estrategia diagnóstica - Indicaciones de la PAAF}

Los dos principales problemas que surgen cuando se pretende elaborar una estrategia diagnóstica para una entidad provisoria y extremadamente frecuente como son los NT en general son los siguientes:

1) Decidir cual o cuales de todas las formas posibles de NT deben ser estudiadas en profundidad. Deben seleccionarse los nódulos de riesgo de alguna forma?

2) Cuáles exámenes se deben aplicar y en que secuencia para obtener el máximo rendimiento diagnóstico y la mejor relación costo-beneficio posible.

\section{Nódulos múltiples, nódulo solitario, nódulo dominante. ¿Qué nódulos se deben puncionar? Significado e implicancias}

Como ya se dijo anteriormente la probabilidad de hallazgo de nódulos tiroideos en la población en general que se somete a UT es de por lo menos $50 \%$, pero puede llegar hasta un $75 \%$. Este dato implica admitir que prácticamente las tres cuartas partes de los seres humanos tienen nódulos tiroideos. La mayor parte de las veces se trata de nódulos múltiples de pocos $\mathrm{mms}$, usualmente menores a $10 \mathrm{mms}$, lo cual explica que no se detecten clínicamente. Sin embargo, alrededor de un $4-5 \%$ de la población presenta uno o mas nódulos palpables, con la particularidad de que cuando se palpa un solo nódulo por lo menos en el $50 \%$ de los casos existen otros inaparentes que pueden ser diagnosticados por la ecografía. Los estudios de autopsia también confirman estos datos, ya que el hallazgo de nódulos tiroideos en ausencia de antecedentes de enfermedad tiroidea puede llegar al 60\% de los casos. De estos datos se desprende que los nódulos múltiples son por lo menos 4 veces mas frecuentes que los nódulos únicos $(1,2,3,4,5,6,7)$. El hallazgo de multinodularidad tiroidea ya sea por la clínica o por las imágenes no es de ninguna manera el equivalente a un diagnóstico de Bocio Multinodular (BMN); el BMN es una entidad en la cual debe haber un aumento del volumen glandular total dentro de determinados parámetros y ademas debe existir un potencial de crecimiento autónomo de los nódulos, hecho que solo puede constatarse con un largo período de seguimiento (8).

La expresión "nódulo tiroideo solitario" (NTS) fue principalmente acuñada en el pasado, cuando solo se disponía de UT de baja resolución, a la cual se le "escapaban" muchos pequeños nódulos múltiples que tenían la mayoría de los pacientes pero que no eran pasibles de detección por los métodos de la época $(1,31)$. En el momento actual el NTS verdadero, es decir sin otros nódulos de ningún tipo que lo acompañen es de hallazgo infrecuente. Sin embargo, en una tiroides ecográficamente homogénea, el hallazgo de un NTS verdadero debe orientar siempre en primer lugar a considerar la posibilidad de una neoplasia tiroidea, con excepción de los raros quistes de paredes finas. Esta neoplasia será la mayor parte de las veces benigna pero también puede ser maligna, y su riesgo de malignidad en el nódulo será por lo menos del doble al de la situación de nódulos múltiples, especialmente si su tamaño supera los $10 \mathrm{mms}: 10 \%$ vs $5 \%$ (1).

La expresión "nódulo dominante" históricamente fue acuñada para referirse al nódulo mayor (el mas grande) en el contexto de un BMN. Se pensaba que este nódulo dominante merecía mayor atención diagnóstica en los pacientes afectados por un BMN, por cuanto su mayor volumen condi- 
cionaba un mayor riesgo de cáncer. En el momento actual esta claramente demostrada la muy baja probabilidad de malignidad en los nódulos del BMN, incluso en el "dominante". La mayor parte de los cánceres de tiroides que se diagnostican en los BMN corresponden a hallazgos incidentales de la anatomía patológica, que solo por excepción se encuentran en los nódulos, y solo muy raramente se localizan en el nódulo dominante (8).

El riesgo global de malignidad de los NT considerados en su conjunto es como ya se dijo de alrededor del $5 \%$. Se ha argumentado en la literatura que el riesgo de malignidad en el caso de pacientes con nódulo único o bien con nódulos múltiples de cualquier tamaño es similar $(5,18)$. Sin embargo, todos los diagnósticos de CT se confirman en base a la selección de nódulos para realizarles PAAF, de tal manera que necesariamente todos los pacientes son "casos seleccionados", y de hecho la mayor parte de los cánceres que se diagnostican en el caso de pequeños nódulos múltiples son microcarcinomas papilares (micro CPT) de dudosa significación clínica. También deben confrontarse estos datos con la probabilidad de hallazgo de microcarcinomas ocultos en piezas de tiroidectomía resecadas por patología benigna y en tiroides obtenidas de autopsias de personas fallecidas por cualquier causa, probabilidad que en ambos casos podemos promediar en un $10 \%$, aunque puede ser mucho mayor dependiendo de la minuciosidad del estudio anátomo-patológico (32). En suma: quiere decir que existe evidencia que sugiere que probablemente por lo menos un $10 \%$ de los seres humanos tienen un microcarcinoma papilar oculto con poca o ninguna significación clínica. Este punto se analiza en profundidad mas adelante.

Entonces es evidente que en realidad decir que los pacientes con nódulos múltiples tienen un riesgo similar al de los nódulos solitarios con independencia del tamaño constituye en opinión del autor una verdad estrictamente estadística pero un error conceptual, puesto que existe un "sobrediagnóstico" de cáncer a expensas de micro CPT "seleccionados" en los casos de pacientes con pequeños nódulos múltiples. El sobrediagnóstico de micro CPT es una consecuencia probablemente indeseable de la "epidemia" diagnóstica de NT(6). En cualquier caso siguiendo esa línea de razonamiento de buena parte de la literatura también podría argumentarse el absurdo de que el riesgo de cáncer para los seres humanos es el mismo independientemente de la presencia o no de nódulos. El error conceptual parte claramente de la no discriminación entre micro CPT "ocultos" y los "cánceres clínicamente significativos"(32).

Si el 5\% de las personas portadoras de NT tiene un cáncer de tiroides (CT) y si los NT estan presentes en digamos un $50 \%$ de la población, quiere decir que la prevalencia de CT en la población debería de ser de unos 2500 casos / 100.000 hab. Sin embargo, aún considerando las cifras mas altas de prevalencia de $\mathrm{CT}$, que son las de EEUU, donde se triplicó la misma por el sobrediagnóstico ya analizado, los casos diagnosticados no superan los $10-12$ casos $/ 100.000$ hab/año. Si consideramos las tasas de hallazgo de CT en piezas de tiroidectomía y autopsias, alrededor de $10 \%$, esto debería dar una prevalencia de CT en la población aún mayor: 10.000 casos/100.000 hab. Estos números indican que son ignorados la enorme mayoría de los micro CPT ocultos de la población en general, y que es evidente que deben considerarse por separado los datos de los cánceres clínicamente significativos por un lado y los de los microcarcinomas ocultos por el otro. Las cifras de mortalidad por CT solo han aumentado ligeramente, apoyando la teoría de la escasa significación de la mayor parte de estos pequeños tumores ocultos $(9,10)$. 
Por lo todo lo expuesto sería absurdo e imposible aplicar la PAAF en todos los nódulos detectados en cualquier situación, considerando ademas datos ya conocidos de que el hallazgo de CT en los nódulos de los BMN es muy poco frecuente y de que el sobrediagnóstico de microcarcinomas en los pequeños nódulos ocultos no reporta significación clínica en la mayoría de los casos. El objetivo por lo tanto debe ser necesariamente aplicar la PAAF solamente en aquellos nódulos que se consideran de riesgo, entendiendo como tal el riesgo de presentar un CT con significación clínica.

\section{Estrategia de selección de nódulos para PAAF}

El valioso estudio de Papini y col (33), publicado en 2002 marcó una "nueva estrategia" acerca de cómo encarar el estudio de los NT no palpables de entre 8-15 mms. Mas de 400 pacientes con NT no palpables fueron estudiados mediante ecografía doppler color y posteriormente citología por PAAF. El objetivo del estudio fue determinar la correlación entre aquellos hallazgos ecográficos de sospecha de malignidad y los resultados finales de la PAAF, evaluando posteriormente si era posible elaborar una estrategia costo - efectiva que permitiera reducir el número de PAAF y de cirugías. Papini demostró que eran factores ecográficos de riesgo de malignidad: nódulo hipoecoico, márgenes irregulares, vascularización central y microcalcificaciones. Si se hubiera practicado la PAAF solo en los NT hipoecoicos con 1 o mas de alguno de los restantes factores de riesgo ecográfico de malignidad se hubieran podido identificar el $87 \%$ de los cánceres. Su recomendación final fue que en el caso de nódulos no palpables de entre 8 - 15 mms solo deberían seleccionarse para PAAF aquellos que se muestren hipoecoicos y con 1 o mas de los restantes signos ecográficos de riesgo, controlando evolutivamente con ecografía en $6-12$ meses a los restantes pacientes.

Esta estrategia sustituyó a la vieja estrategia de seleccionar a los NT para PAAF solamente con el rígido criterio del tamaño mayor a $10 \mathrm{mms}$ independientemente de sus características ecográficas, con el cual se sobreindicaban punciones inútilmente y eran ignorados muchos cánceres pequeños. Este criterio ha sido adoptado casi universalmente con ligeras variantes para el estudio selectivo de los nódulos tiroideos no palpables. En la práctica se ha establecido que los pacientes portadores de NT menores a $10 \mathrm{mms}$ (no palpables), independientemente de que tengan un nódulo único o nódulos múltiples, solo se indicará la PAAF selectivamente en el o los nódulos que presenten alguno de los criterios ecográficos de malignidad establecidos por Papini $(1,6,7,34)$.

Esta misma estrategia ha demostrado ser igualmente costo-efectiva para seleccionar cual o cuales nódulos deben ser puncionados en aquellos pacientes portadores de un BMN, donde la PAAF sistemática tiene un muy bajo rendimiento diagnóstico. Solo deberían ser puncionados el o los nódulos que presenten elementos ecográficos de sospecha de malignidad tal como se realiza para los nódulos de menos de $10 \mathrm{mms}(8,35,36)$. El viejo concepto de "nódulo dominante" pasó a ser sustituído por el nuevo concepto de "nódulo discordante", término introducido en nuestro medio por Crestanello (2), donde la "discordancia" esta determinada por la presencia de factores ecográficos de riesgo en un determinado nódulo y no simplemente por su tamaño.

La guía de la AACE/AME (5) recomienda la misma conducta que hemos expuesto tanto para los nódulos no palpables como para los palpables, sin ninguna discriminación entre nódulo solitario versus nódulos múltiples, estableciendo a la ecografía doppler color como la única base en la que se sustenta la indicación de la PAAF. 
Sin embargo, en opinión del autor tanto el NTS verdadero mayor a $10 \mathrm{mms}$, como su equivalente, es decir un NT mayor a $10 \mathrm{mms}$ en un contexto de otros micronódulos múltiples (donde el mayor a $10 \mathrm{mms}$ es de hecho "discordante" del resto) merecen una consideración aparte. Estas son situaciones donde el primer diagnóstico a plantear es la neoplasia tiroidea. Unos pocos micronódulos banales en una misma glándula donde resalta un nódulo mayor a $10 \mathrm{mms}$ no invalidan esta presunción. El riesgo de malignidad en estas situaciónes específicas es mayor que en los NT en general de acuerdo a la vasta experiencia acumulada en el pasado en referencia al encare diagnóstico del NTS, probablemente alrededor de un $10 \%$. A este dato no menor debe agregarse el hecho de que no siempre es posible contar en nuestro medio con ecografía de calidad, y que aún contando con ella existe un pequeño porcentaje de casos de CT que escapan al diagnóstico con la metodología descrita precedentemente. El agravante en este caso a juicio del autor es que podrían ignorarse no ya microcarcinomas sino CT mayores a $10 \mathrm{mms}$ con los potenciales riesgos que ello implica. Por todo ello se propone que en el caso de NTS mayor a $10 \mathrm{mms}$, ya sea verdadero o su equivalente como ya se explicó, sea realizada la PAAF en forma sistemática independientemente de sus características ecográficas (1). A favor de esta propuesta influye de alguna manera las recomendaciones de la American Thyroid Association (ATA) que en su 5 a recomendación para el estudio de los NT admite la PAAF en el estudio de los NT sólidos mayores de $10 \mathrm{mms}$ hipoecoicos (recomendación de clase B) pero también iso o hiperecoicos (recomendación de clase C) sin ninguna otra característica ecográfica de malignidad. La ATA no aclara si esta recomendación es para NTS o para cualquier nódulo (37).

Otra recomendación importante de la ATA es la PAAF sistemática en aquellos NT incidentales que se detectan por PET-SCAN, que como ya vimos tienen por lo menos un $40 \%$ de riesgo de malignidad $(7,37)$

\section{En suma, las indicaciones de PAAF en los NT serían:}

- Nódulos únicos o múltiples menores a 10 mms: Solamente en aquellos nódulos seleccionados por ecografía doppler color o bien en los detectados por PET-SCAN.

- Nódulos múltiples del BMN: Solamente en aquellos nódulos seleccionados por ecografía doppler color.

- NTS o su equivalente mayor a 10 mms: Sistemática, independientemente de la ecografía (a propuesta del autor).

\section{Los criterios de sospecha de malignidad por Eco-Doppler color son:}

- Nódulo hipoecoico

- Márgenes nodulares irregulares o infiltrativos

- Presencia de vascularización central (tipo III de Messina)

- Presencia de microcalcificaciones 


\section{If) Interpretación del informe citológico y conducta a seguir}

La interpretación contemporánea de los informes citológicos, así como su clasificación e implicancias terapeúticas están estandarizadas por el Instituto Nacional del Cáncer de Estados Unidos a partir del año 2007 en lo que se ha denominado el Sistema Bethesda Para Informar la Citopatología de Tiroides, o simplemente la "Clasificación Bethesda" (26).

\section{La Clasificación Bethesda es la siguiente:}

- Categoría I: Muestra no diagnóstica o insatisfactoria

- Categoría II: Resultado benigno

- Categoría III: Atipía de significado incierto o lesión folicular de significado incierto

- Categoría IV: Neoplasia folicular o presunta neoplasia folicular

- Categoría V: Diagnóstico presuntivo de cáncer

- Categoría VI: Resultado maligno

\section{Cat I. Muestra no diagnóstica o insatisfactoria}

En el sistema Bethesda la categoría no diagnóstica o insatisfactoria (se utilizan indistintamente) fue creada para referirse a todas aquellas muestras citológicas que se consideran insuficientes o inaceptables para su correcto diagnóstico. Los criterios que definen esta categoría son los siguientes $(26,38)$.

La evaluación de la aceptabilidad de la muestra citológica, por ser de tipo subjetiva, suele ser controvertida entre los diferentes citopatólogos, pero el sistema Bethesda ha convenido en declarar como criterio mínimo de aceptabilidad la presencia de por lo menos 6 grupos celulares con al menos 10 células foliculares de aspecto benigno en cada grupo. Constituyen excepción la presencia de atipías celulares (sube de categoría), células inflamatorias (resultado benigno) o bien nódulos coloides puros o casi puros (resultado benigno). La obtención de líquido de quiste con celularidad menor a la establecida se considera muestra no diagnóstica.

Problemas tales como abundante contenido hemático o bien artefacto por coagulación sanguínea también son causa frecuente de muestra insatisfactoria.

\section{Conducta a seguir}

La conducta en estos casos es efectuar una nueva PAAF no antes de los tres meses, para evitar que los cambios reactivos o reparativos post-PAAF puedan alterar la correcta lectura del citograma. La nueva PAAF suele ser diagnóstica en un $60 \%$ de los casos. La gran mayoría de los casos de muestras no diagnósticas o insatisfactorias terminan siendo nódulos benignos. 
En el caso de los nódulos quísticos el porcentaje de muestras inadecuadas suele ser elevado, sobre todo si no se utiliza la guía ecográfica para puncionar selectivamente la porción sólida de los NT mixtos; los quistes puros de paredes finas son raros y en definitiva la probabilidad de malignidad de los nódulos mixtos es la misma que en los sólidos. Si se obtiene una 2a PAAF de resultado no diagnóstico deberán tomarse en cuenta todos los aspectos clínicos y ecográficos del nódulo en cuestión durante su seguimiento. La presencia de alguno de los signos ecográficos de sospecha de malignidad y/o el crecimiento de un quiste luego de su evacuación primaria completa son indicaciones para cirugía, especialmente si el quiste es mayor de $3 \mathrm{cms}$,ya que en este caso la probabilidad de malignidad es mayor $(1,38,39,40,41)$.

\section{Cat II. Resultado benigno}

El resultado benigno se observa aproximadamente en el 65\% de las PAAF, y se asocia con un riesgo muy bajo de malignidad, de entre 0-3\%. Los resultados benignos son en su gran mayoría nódulos foliculares benignos, en segundo lugar tiroiditis y en tercer lugar otras causas raras. Los criterios que definen la categoría benigna son los siguientes (42).

\section{Nódulo folicular benigno}

El diagnóstico genérico de "nódulo folicular benigno" abarca un espectro de lesiones benignas de citología similar que van desde los nódulos coloides a los nódulos hiperplásicos (o adenomatosos), nódulos por enfermedad de Graves, y un subgrupo menos frecuente de adenomas macrofoliculares. Los nódulos foliculares benignos pueden contener sustancia coloide, células foliculares de aspecto benigno, células de Hürthle y macrófagos en cantidades diversas. El componente celular es generalmente de tipo macrofolicular, aunque en forma infrecuente pueden también observarse microfolículos; no deben existir atipías celulares. Las células de Hürthle aparecen aisladas o bien en láminas planas.

Los nódulos coloides contienen abundante coloide y mínima celularidad, los nódulos hiperplásicos contienen moderada celularidad y escaso coloide. Las células se agrupan en macrofolículos, y cuando hay microfolículos estos estan siempre en minoría, a diferencia de lo que sucede con las neoplasias foliculares (cat IV). Las células de Hürthle pueden ser abundantes, pero en el caso de neoplasia de células de Hürthle estas se encuentran con exclusividad o casi exclusividad en relación a las células tiroideas comunes. Un adenoma macrofolicular con abundante coloide es indistinguible citológicamente de un nódulo hiperplásico. Los nódulos de la Enf de Graves,si bien son poco frecuentes, tienen aspecto similar al de los restantes nódulos foliculares benignos, pero en aquellos pacientes tratados con Yodo 131 pueden exhibir atipías que hagan pensar equivocadamente en un carcinoma. No obstante lo anterior debe tenerse en cuenta que la probabilidad de Carcinoma Papilar de Tiroides en nódulos fríos de la Enf. de Graves es de alrededor de 25\% (43). 


\section{Tiroiditis}

La tiroiditis linfocitaria crónica o enfermedad de Hashimoto se caracteriza por la presencia de gran cantidad de linfocitos polimorfos acompañados de células de Hürthle en un contexto de hiperplasia celular (sobreestimulación por TSH), pero en casos avanzados la fibrosis puede ser importante. Los linfocitos pueden agruparse en folículos linfáticos completos o "infiltrar" el componente epitelial. Las células de Hürthle aparecen en forma aislada o dispuestas en láminas planas, y no es infrecuente que tengan leves atipías sin significación maligna.

La tiroiditis granulomatosa o subaguda de De Quervain se caracteriza por los granulomas en los casos típicos.

La tiroiditis aguda es una infección aguda de la tiroides, con un citograma caracterizado por abundantes neutrófilos, piocitos, necrosis, fibrina, macrófagos y hematíes. El componente celular y coloide es escaso. Ocasionalmente se observan bacterias y/o hongos.

La tiroiditis de Riedel es la menos frecuente, y se caracteriza por fibrosis glandular que se extiende a los tejidos vecinos del cuello, con una tiroides muy dura a la palpación.. El citograma se caracteriza por la ausencia de células foliculares y coloide, así como tractos de colágeno y células fusiforme benignas.

\section{Conducta a seguir}

Los pacientes con citograma benigno se controlan evolutivamente mediante clínica y ecografía cada 6-12 meses durante 3-5 años. La PAAF se repite solamente si hay crecimiento significativo del nódulo o bien si hay viraje de las características ecográficas a elementos de sospecha de malignidad, lo cual no es un hecho frecuente.

La tasa de falsos negativos en la literatura oscila en un 1-10\%, pero son datos con un sesgo de selección, ya que se obtienen mayoritariamente de pacientes operados y resecados. En los seguimientos a largo plazo (5-10 años) se han informado tasas de malignidad de solo $1 \%(42,44)$.

\section{Cat III. Atipia de significado incierto o lesión folicular de significado incierto}

Esta categoría se observa en un $3-18 \%$ de los citogramas tiroideos, y contituye una suerte de último recurso. El riesgo de malignidad, considerando los pacientes que se resecan y también todos aquellos en los cuales se opta por el seguimiento a largo plazo es de 5-15\%. Sin embargo el porcentaje de malignidad en los resecados a corto plazo puede llegar a 25\%. El término"atipía de significado incierto" (ASI) se utiliza para referirse a las células ya sean foliculares, linfocitos, u otras que presentan un grado de atipía estructural o nuclear que no es suficiente para clasificarlas como neoplasia folicular,presunción de malignidad, o bien maligno. El término "lesión folicular de significado incierto" (LFSI) es equivalente al anterior pero solamente cuando la atipía se localiza específicamente en las células foliculares y no otras. La definición de esta categoría siempre es compleja y cargada de subjetividad, y por lo tanto controversial entre los diferentes citopatólogos. A continuación se 
exponen sus principales características en forma simplificada, por cuanto existe una gran heterogeneidad de situaciones en esta categoría(45).

En el caso de LFSI, que es el mas común, existen varios hallazgos citopatológicos que encuadran dentro de esta categoría:

\section{Atipías estructurales}

- Población prominente de microfolículos pero con escasa celularidad y escaso coloide, no calificando porlo tanto para "neoplasia folicular"

- Celularidad moderada con proporción de microfolículos mayor que la habitual pero insuficiente para configurar "neoplasia folicular"

- Predominio de células de Hürthle pero con escasa celularidad y escaso coloide; o bien moderada celularidad de células de Hürthle en un contexto indicativo de nódulo benigno de células de Hürthle, por ejemplo Tiroiditis de Hashimoto y BMN.

- Presencia de artefactos que no permiten definir con claridad el grado de atipía

\section{Atipías nucleares}

- Atipías nucleares focales parecidas a las del Carcinoma Papilar, pero el resto mayoritario del frotis, es decir la mayor parte de la celularidad, es de tipo benigno.

- Atipías nucleares moderadas y focales en una muestra obtenida de pared de un quiste tiroideo, con el resto de la muestra de aspecto normal

- Atipías nucleares moderadas en pacientes tratados con drogas antitiroideas, Yodo 131 u otros fármacos, o bien cambios reparativos por involución o hemorragia.

En el caso de ASI (no folicular) las atipías se encuentran fundamentalmente en una población linfocitaria, pero sus características no permiten catalogarlas como presunción de malignidad, es decir en este caso linfoma.

\section{Conducta a seguir}

El informe de ASI o bien LFSI debe considerarse dentro del contexto clínico del paciente en particular. Si existen elementos ecográficos de sospecha de malignidad muy evidentes entonces procede la cirugía, pero la situación mas frecuente es que no estén presentes y que el citograma deba repetirse en el lapso de unos tres meses. La 2a PAAF suele ser diagnóstica en el 75\% de los casos. En el $25 \%$ restante que se vuelve a repetir el diagnóstico de ASI o LFSI generalmente esta indicada la cirugía, con una probabilidad de hallazgo de cáncer de 20-25\%, pero también es factible un seguimiento mas estrecho. 
Algunos autores partidarios de la cirugía para todas estas lesiones (LFSI) informan tasas de hallazgo final de cáncer de $16 \%$, pero es un porcentaje seleccionado, por cuanto todos los pacientes fueron operados a corto plazo. También utilizan como argumento a favor de la cirugía un porcentaje de hallazgo de Micro CPT incidental de $21 \%$ en los tiroides resecados, lo cual como ya se explicó anteriormente es por lo menos muy discutible (46).

Sin embargo, debe prestarse especial atención a las atipías que remedan los cambios citológicos típicos del CPT, ya que aún consideradas como insuficientes para el diagnóstico de presunción de CPT (y por lo tanto clasificadas como ASI) han revelado en los casos operados una tasa de hallazgo final de CPT de $30-75 \%$. Estos hallazgos justifican la repetición sistemática de la PAAF y de persistir estos hallazgos la tiroidectomía con extemporánea(45,47).

\section{Cat IV. Neoplasia folicular y presunta neoplasia folicular}

Las lesiones foliculares de la tiroides comprenden a los nódulos hiperplásicos, Adenoma folicular, Carcinoma Folicular y en menor medida a la variante folicular del Carcinoma Papilar. Todos ellos, con la excepción de la variante folicular del CPT, tienen características citologicas que se superponen y hacen casi imposible su diferenciación solamente por la citología. Sin embargo, existen algunas características citológicas que inducen a plantear una neoplasia tiroidea benigna o maligna y que son las que definen esta categoría. El diagnóstico final es siempre de la Anatomía Patológica definitiva sobre la totalidad del nódulo resecado, ya que solo por esta vía puede demostrarse invasión capsular y/o vascular, hallazgos que definen al carcinoma folicular. Como dentro de las neoplasias foliculares estan todos los carcinomas foliculares puede considerarse que la PAAF hace una especie de tamizaje de los nódulos foliculares, seleccionando para cirugía solo aquellos que tienen mayor probabilidad de ser malignos. En la clasificación Bethesda se consideran igualmente aceptables para definir la categoría IV tanto la expresión "neoplasia folicular" como "presunta neoplasia folicular". Dado que alrededor de un 35\% de los informes de neoplasia folicular corresponden en realidad a nódulos hiperplásicos se justifica plenamente el informe de "presunta neoplasia folicular" en vez de "neoplasia folicular" de algunos patólogos. Se exponen a continuación las principales características que definen a esta categoría (48).

Se trata de extendidos de celularidad moderada a abundante, compuestos principalmente por células foliculares con una disposición anómala, fundamentalmente microfolículos con nada o escaso coloide, o bien agrupamiento, superposición o trabéculas densamente celulares. Las atipías nucleares leves son posibles y no significan malignidad, ya que se observan con frecuencia en los adenomas foliculares y los nódulos hiperplásicos.

Se debe prestar especial atención a la características de las células foliculares, única forma de diagnosticar la variante folicular del CPT, donde de hecho no hay papilas; si se detectan cambios citológicos que sugieren CPT corresponde clasificar el caso como "presunción de malignidad"o "presunción de CPT" y no como neoplasia folicular. 


\section{Neoplasia folicular de células de Hüthle y presunta neoplasia folicular de células de Hürthle}

La célula de Hürthle (CH) es una célula folicular de la tiroides que se caracteriza por abundante citoplasma eosinófilo de aspecto finamente granular y un núcleo agrandado con un nucleolo muchas veces prominente. Las $\mathrm{CH}$ se encuentran habitualmente en la Tiroiditis de Hashimoto, en el BMN y también en casos de hipertiroidismo. De acuerdo a las pautas de la OMS tanto el adenoma (ACH) como el carcinoma de células de Hürhtle $(\mathrm{CCH})$ constituyen variantes del adenoma y el carcinoma foliculares, pero no es una opinión compartida por todos los autores. Las diferencias morfológicas notables entre ambos cuadros citológicos y las diferencias genéticas también importantes entre los tumores foliculares y los de $\mathrm{CH}$ hacen que en la clasificación Bethesda se diferencien ambas estirpes celulares. Es así que se debe consignar si se trata de neoplasia folicular simple o a $\mathrm{CH}$ dentro de la misma categoría $(49,50)$. En el sistema Bethesda se consideran aceptables los mismos términos, es

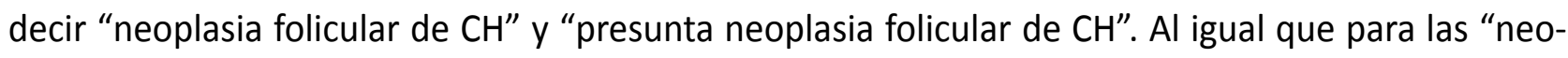
plasias foliculares" un $16-25 \%$ de estos citogramas terminan siendo nódulos hiperplásicos de $\mathrm{CH}$ en un contexto de tiroiditis o BMN y no verdaderas neoplasias. Tanto en el BMN como en la tiroiditis de Hashimoto es posible puncionar nódulos hiperplásicos benignos de buen volumen compuestos exclusivamente por células de Hürthle. Dentro de las neoplasias de $\mathrm{CH}$ la proporción de $\mathrm{CCH}$ es de $20 \%$ y la de adenomas $80 \%$, es decir la misma que para los tumores foliculares simples; la distinción entre adenomas y carcinomas también se basa en demostrar invasión capsular o vascular en la histología, al igual que para los tumores foliculares. Quiere decir que salvo por la consignación de una diferente terminología, un aspecto citológico diferente y una genética diferente, todos los demas criterios para su inclusión y análisis dentro del sistema Bethesda son similares que para "neoplasia folicular" $(49,50)$. Los criterios diagnósticos de esta variante de la categoría IV son los siguientes (49).

Los extendidos citológicos se caracterizan por una celularidad moderada a abundante exclusivamente o casi exclusivamente constituída por $\mathrm{CH}$. Las células pueden ser grandes o pequeñas, con abundante citoplasma granular eosinofílico, núcleos redondos voluminosos y nucleolo prominente, con muy escasa o ausente sustancia coloide. De acuerdo a los criterios de la OMS se consideran neoplasias de $\mathrm{CH}$ a aquellas constituídas por $75 \%$ o mas de estas células sobre las células foliculares comunes; este mismo criterio es incorporado para elaborar los informes utilizando el sistema Bethesda, si no se llega al porcentaje de $\mathrm{CH}$ debe informarse como neoplasia folicular común. La presencia de células de Hürthle en proporciones menores en otro tipo de extendidos celulares no juega ningún papel en el incremento de riesgo de malignidad y no debe incidir por lo tanto en la elaboración del informe, su clasificación en el sistema Bethesda y tampoco en la indicación de cirugía (51).

\section{Conducta a seguir}

La conducta estándar recomendada tanto para la neoplasia folicular como para la neoplasia folicular de $\mathrm{CH}$ es la resección quirúrgica de la lesión, habitualmente una lobectomía. Como casi todos los pacientes son operados existen datos estadísticos muy precisos de los resultados finales. El porcentaje de citologías por PAAF clasificadas como neoplasia folicular o bien de $\mathrm{CH}$ es de $15-30 \%$ (37). La probabilidad de que un NT clasificado como neoplasia folicular sea realmente una neoplasia (adenoma o carcinoma) es alta, $65-85 \%$, pero la probabilidad global de malignidad en esta categoría es de solo $12-32 \%$, por cuanto dentro de las neoplasias foliculares o de $\mathrm{CH}$ verdaderas hay un 
$80 \%$ de adenomas y solo un $20 \%$ de carcinomas. Sin embargo, aún en la eventualidad de malignidad el porcentaje de carcinomas foliculares no es el esperado, y de hecho un 27-68\% terminan siendo CPT. La explicación de estos resultados radica probablemente en una alta tasa de variante folicular de CPT y también en una incapacidad de muchos citólogos en identificar cambios citológicos mínimos pero típicos del CPT en la citología por PAAF (48).

Sin embargo, recientemente han surgido algunos estudios en los cuales se ha intentado "tamizar" a los pacientes con informes de categoría IV, tratando de identificar por distintos métodos cuáles de esos pacientes tienen una mayor probabilidad de cáncer y así intentar evitar realizar tiroidectomías innecesarias. Debe recordarse que la probabilidad de malignidad es de solo $12-32 \%$, lo cual es indicativo que aún se practican muchas tiroidectomías que al menos en teoría serían innecesarias. Los mayores avances en este sentido se han logrado con el uso de los marcadores genéticos y el PET-SCAN.

\section{Marcadores genéticos - Diagnóstico molecular}

Existen marcadores genéticos (mutaciones) que han sido identificados con mayor frecuencia en lesiones foliculares malignas que en las benignas y viceversa. Ya se comercializa en el mercado un panel de marcadores genéticos para utilizar en la investigación de citogramas clasificados como neoplasia folicular (Afirma Veracyte). Según los primeros reportes al parecer se han logrado reducir significativamente el número de tiroidectomías para lesiones finalmente benignas. El método demuestra una buena sensibilidad pero una baja especificidad, y por lo tanto una tasa aún alta de falsos positivos. De acuerdo a estos estudios el diagnóstico molecular se muestra como un método promisorio a futuro, pero de eficacia y costo - efectividad aún no claramente establecida $(52,53)$. En las Thyroid Nodule Guidelines de la American Thyroid Association (ATA) del 2009 (37) se reconoce la existencia de estos paneles de diagnóstico molecular y su eventual utilidad, pero se establece claramente que aún se necesita acumular mayor experiencia clínica para recomendar su uso sistemático en el tamizaje de las "neoplasias foliculares". El grado de recomendación para su uso es de nivel C.

\section{PET-SCAN}

Los nódulos tiroideos malignos suelen tener una especial avidez en la captación de la Flúor Desoxiglucosa (FDG) en el PET-SCAN, y de hecho es una de las formas en que se detectan incidentalomas tiroideos, con una probabilidad de malignidad de $40 \%$ (7). Esta particularidad del PET-SCAN ha sido utilizada para el tamizaje de los nódulos foliculares de categoría IV de la clasificación Bethesda, con los mismos objetivos descritos para los marcadores genéticos. Un estudio reciente encontró cierta utilidad en el uso del PET-SCAN en nódulos mayores de $2 \mathrm{cms}$ sin componente oncocítico (no Hürthle), informando una reducción de tiroidectomías por nódulos benignos de $13-25 \%$ en una serie pequeña (30). Sin embargo, la gran variabilidad de captación de la tiroides normal y la baja especificidad del PET-SCAN, teniendo en cuenta que el $60 \%$ de los adenomas foliculares captan FDG (falsos positivos), hacen de este método de tamizaje un recurso insuficiente (54). Las guías de la ATA (37) también mencionan al PET-SCAN haciendo notar su buena sensibilidad pero su baja especificidad, por lo cual no lo recomiendan como uso rutinario. 


\section{Cat V. Diagnóstico presuntivo de cáncer}

Los tumores malignos primarios de la tiroides diagnosticables por la citología, es decir básicamente el Carcinoma Papilar (CPT), el Carcinoma Medular (CM, el Carcinoma Anaplásico (CA) y el Linfoma Tiroideo (LT), son generalmente de fácil diagnóstico citológico. Sin embargo, ocasionalmente los extendidos pueden ser de escasa celularidad, mala calidad, o bien presentar variantes citológicas menos comunes de los tipos histológicos mencionados,o también superposición de una citología no clara sobre un fondo de otra patología preexistente como la tiroiditis. En estas situaciones si no es claro el diagnóstico de malignidad debe clasificarse como presuntivo de cáncer y no maligno. A esto debe agregarse la gran dificultad o casi imposibilidad de diagnosticar los Carcinomas Foliculares (CF) y los carcinomas de Células de Hürthle (CCH) por la PAAF,por lo cual también pueden ocasionalmente ser clasificados como de presunción de malignidad. De cualquier manera la mayor parte de los diagnósticos presuntivos de maligidad terminan siendo CPT confirmados en el estudio extemporáneo. Alrededor de un $2-8 \%$ de los informes citológicos son clasificados como presunto carcinoma, sobre todo CPT. El valor predictivo positivo de esta categoría se considera debe estar por encima del $50 \%$, oscilando en los diferentes estudios entre $55-85 \%$. Las principales características de esta categoría para los diferentes tipos histológicos son las siguientes (55).

\section{Presunto CPT}

Cambios nucleares aislados: Celularidad moderada o abundante con células foliculares benignas predominantes y algunas que presentan cambios nucleares como agrandamiento, palidez, hendiduras, irregularidad de membrana y moldeado.

Cambios nucleares incompletos: Celularidad escasa, moderada o abundante con agrandamiento nuclear leve, palidez nuclear leve y hendiduras.

Escasa celularidad: Se aprecian características sugestivas de CPT pero la muestra es de escasas células como para afirmar el diagnóstico.

Degeneración quística: En un contexto de macrófagos y células espumosas se observan células foliculares de núcleos grandes y pálidos y algunas con hendiduras nucleares.

\section{Presunto CMT}

En estos casos la celularidad es escasa o moderada, a células medianas o pequeñas con una alta relación núcleo-citoplasmática a diferenciar entre CMT y LT. Ocasionalmente se puede identificar sustancia amiloide en el extendido, lo cual aboga a favor del CMT.

\section{Presunto LT}

Se trata de un extendido compuesto por numerosos linfocitos monomorfos pequeños a medianos, o bien un extendido de escasa celularidad y linfocitos atípicos. 


\section{Otros}

Tanto el CA como el Carcinoma Pobremente diferenciado (CPD) y las metástasis tiroideas de tumores alejados pueden presentar cuadros citológicos de presunción de malignidad no claramente definidos.

\section{Conducta a seguir}

La conducta a seguir en estos casos es la resección quirúrgica, como mínimo una lobectomía con confirmación anátomo-patológica intraoperatoria y actuar en consecuencia; de confirmarse la naturaleza maligna corresponde realizar una TT. Sin embargo, en algunos casos, sobre todo cuando el nódulo problema es voluminoso, de mas de 3 o $4 \mathrm{cms}$, estaría indicada la TT de entrada prescindiendo de la confirmación intraoperatoria para esta indicación. La utilización de la inmunohistoquímica para calcitonina es de gran valor diagnóstico cuando se sospecha CMT, así como la citometría de flujo lo es cuando se sospecha LT (55).

\section{Cat VI. Carcinoma Tiroideo}

Entre un 4-8\% de todas las PAAF tiroideas son clasificadas como positivas para malignidad, y la gran mayoría son CPT. De los casos informados como CPT $96-100 \%$ se confirman finalmente como CPT en la histología. EI CPT convencional se caracteriza por la presencia de numerosas papilas revestidas de células foliculares tumorales con características nucleares muy particulares. La ausencia de papilas no invalida el diagnóstico, ya que la citología característica es la que verdaderamente define todas las variantes del CPT. Se resumen sus principales características (56).

\section{Carcinoma papilar. Criterios diagnósticos comunes:}

- Disposición celular tanto en papilas como en monocapas

- Agrandamiento nuclear

- Núcleos ovalados o irregulares a veces con superposición

- Indentaciones nucleares ("grooves")

- Seudoinclusiones citoplasmáticas intranucleares

- Núcleos pálidos "vacíos" con cromatina pulverulenta en "vidrio esmerilado" semejantes a los ojos de caricatura de "Annie la huerfanita"

- Ocasional metaplasma oncocítica (células de Hürthle)

- Ocasional metaplasma escamosa

- Cuerpos de Psammoma

\section{Variante folicular:}

Se trata de un CPT compuesto en su totalidad por folículos pequeños revestidos por células con las alteraciones nucleares características ya descritas. No existen papilas y a diferencia del CPT con- 
vencional los cambios nucleares suelen ser mas sutiles, y pueden plantear dificultades de diagnóstico con el resto de las lesiones foliculares de la tiroides. Es la variante mas frecuente, representando hasta un $30 \%$ de los CPT; su comportamiento biológico es similar.

\section{Variante macrofolicular:}

Es una variante folicular con mas del $50 \%$ de los folículos dispuestos como macrofolículos. También se caracteriza por atipías nucleares mas sutiles y por lo tanto es de diagnóstico diferencial difícil con el resto de los nódulos foliculares.

\section{Variante quística:}

Se caracteriza por quistes que contienen líquido fluído, histiocitos y células tumorales multivacuoladas con los cambios nucleares característicos. Debe tenerse en cuenta que alrededor de un $10 \%$ de los CPT son completamente quísticos. Se cree que la mayoría de las PAAF con resultados falso negativo para CPT corresponden en su mayoría a variantes quísticas.

\section{Variante oncocítica:}

Es un tumor que presenta los cambios nucleares característicos del CPT pero que esta compuesto principalmente por células de Hürthle (oncocitos) con o sin papilas. Se trata de una variante mas agresiva que el CPT convencional y muestra una menor linfofilia. A pesar de que prestigiosos autores como Li Volsi clasifican a este tumor dentro de los CPT otros creen que debe clasificarse dentro de los $\mathrm{CCH}(50)$.

\section{Variante tipo Warthin:}

Es un tumor de arquitectura papilar con células con las características típicas del CPT pero que asocia folículos linfoides que remedan el tumor de Warthin de la Parótida. Las celulas son oncocíticas y por lo tanto la presencia de oncocitos y linfocitos plantea el diagnóstico diferencial con la tiroiditis de Hashimoto.

\section{Variante de células altas:}

Es una forma mas agresiva de CPT formada por papilas de células mas elongadas o "altas", con una altura triple del ancho celular. Los cambios nucleares son los característicos y la células altas deben reprentar al menos el $50 \%$ del tumor para que encuadre dentro de esta subcategoría.

\section{Variante de células cilíndricas:}

Es otra variante mas gresiva de CPT compuesta por papilas de células cilíndricas con cambios nucleares menos evidentes y con núcleos mas hipercromáticos. 


\section{Otras variedades:}

Otras variantes tales como el tumor trabecular hialinizante, la variante sólida, cribiforme, morular y esclerosante difusa son variantes mas raras de muy difícil diagnóstico citológico y que en definitiva se distinguen por la histología definitiva.

\section{Carcinoma medular}

Se exponen someramente algunos de los criterios diagnósticos que permiten evaluar citológicamente en Carcinoma Medular de tiroides (CMT) ya que ocasionalmente puede plantear algún diagnóstico diferencial con los tumores diferenciados. EI CMT presenta una gran heterogeneidad morfológica en la citología, debido a la existencia de un gran número de variantes anátomo-patológicas. Las principales características citológicas se resumen a continuación $(50,57)$.

- Celularidad moderada a abundante

- Células poligonales, redondeadas, fusiformes, plasmocitoides, mas raramente células gigantes anómalas, con pleomorfismo nuclear moderado.

- Núcleos redondeados y excéntricos con cromatina finamente granular.

- Citoplasma granular en cantidad variable

- Sustancia amiloide

- En la Inmunohistoquímica las células son positivas para calcitonina y frecuentemente también para CEA, pero son negativas para tiroglobulina

- El diagnóstico diferencial mas frecuente es con el $\mathrm{CCH}$.

\section{Carcinoma pobremente diferenciado}

El carcinoma pobremente diferenciado (CPD) es un tumor poco frecuente que presenta una agresividad biológica intermedia entre la de los tumores bien diferenciados y el carcinoma anaplásico. El tumor se origina a partir de las células foliculares, sus principales características citológicas son las siguientes $(50,58)$.

- Celularidad abundante con disposición en "ínsulas" (variante insular) o bien en formaciones sólidas o trabeculares

- A veces se entremezcla con un CPT o CF de base, marcando siempre un peor pronóstico

- Células malignas con alto índice núcleo-citoplasmático y atipía celular variable

- Actividad mitótica importante

- Presencia de necrosis 
El diagnóstico citológico suele ser difícil, por tratarse de un tumor de baja frecuencia, con características parecidas a las de las neoplasias foliculares y por existir escasa experiencia en su diagnóstico por parte de los citólogos.

\section{Carcinoma anaplásico}

Es un tumor de alta malignidad y mal pronóstico vital, que raramente se presenta como un NT, sino mas bien como una masa pétrea de rápido crecimiento y compromiso de estructuras vecinas, dato muy importante a tener en cuenta para el diagnóstico citológico. Frecuentemente existen metástasis ganglionares y pulmonares. Se trata de un tumor pleomorfo y de alto grado; los criterios de diagnóstico citológico mas útiles son los siguientes $(50,59)$.

- Celularidad abundante

- Células aisladas o en grupos de diverso tamaño

- Células redondeadas, poligonales o fusiformes desde pequeñas a gigantes

- Núcleos pleomorfos intensamente atípicos, a veces multinucleación

- Necrosis, fibrosis, infiltrado inflamatorio

- Numerosas mitosis anómalas

- Es posible encontrar focos o bien un fondo de CPT o CF entremezclados

\section{Linfoma tiroideo}

El Linfoma Tiroideo (LT) puede localizarse en la tiroides como un tumor primario o bien como parte de una enfermedad sistémica. Los LT primarios se asocian casi invariablemente a la Tiroiditis de Hashimoto y suelen ser Linfomas no Hodgkin a linfocitos B y de tipo MALT (50). Las principales características citológicas del LT son las siguientes (60).

- Celularidad abundante con una población linfocitaria monomorfa

- Células linfáticas en general grandes, doble tamaño que las normales

- Núcleos densos con nucleolos prominentes

- Ausencia de células foliculares

- Presencia de necrosis

- En general fácil diferenciación con la Tiroiditis de Hashimoto

\section{Metástasis tiroideas}

Los carcinomas metastáticos tiroideos se encuentran en los estudios de autopsia de personas fallecidas por causa oncológica hasta en el $10 \%$ de los casos. La forma de presentación puede ser micrometástasis múltiples, nódulo único voluminoso, o bien infiltración difusa tiroidea. La presentación a nódulo único es la que puede plantear mas frecuentemente el diagnóstico diferencial con los 
tumores tiroideos primarios. La descripción detallada de la citología de todas las estirpes tumorales posibles que pueden metastatizar la tiroides escapa a los objetivos de este trabajo, pero el listado de tumores extratiroideos que pueden metastatizar la tiroides y eventualmente ser pasibles de diagnóstico citológico son los siguientes $(50,60)$.

- Cáncer de riñón

- Melanoma maligno

- Cáncer de mama

- Cáncer de pulmón

- Otros menos frecuentes (colon, estómago, etc)

\section{Conducta a seguir con el resultado maligno en la PAAF}

En el caso de los carcinomas tiroideos mas frecuentes la conducta a seguir es siempre la resección quirúrgica, usualmente la TT asociada o no al vaciamiento ganglionar de acuerdo a la estirpe histológica, estadio tumoral, presencia o no de ganglios y otras consideraciones que no corresponde analizar aquí. Puede discutirse la necesidad o no de confirmar el diagnóstico en el intraoperatorio por anatomía patológica extemporánea, lo cual dependerá de la confianza que se tenga en el informe citológico u otras razones que tampoco corresponde analizar en esta sección. En el caso del carcinoma anaplásico es común que existan criterios de irresecabilidad, por lo cual la cirugía resectiva primaria suele no ser posible. En el caso del LT la indicación quirúrgica dependerá de si se trata de un LT primario o bien sistémico, y de si existe o no una indicación de tratamiento sistémico de entrada. Las metástasis tiroideas solo se consideran quirúrgicas si son la única localización metastásica de un tumor primario ya resecado o controlado, o bien como cirugía paliativa en caso de complicaciones locales de las mismas $(50,60)$.

\section{Ig) Resumen de estrategia diagnóstica en el nódulo tiroideo}

De acuerdo a todo lo expuesto precedentemente se puede resumir la estrategia y secuencia diagnóstica del NT de acuerdo al orden siguiente:

1으 Solicitar una UT (EDC o bien EPA) y una dosificación de TSH. Eventualmente, si existe evidencia clínica de disfunción tiroidea se solicitará de entrada T3, T4 y TSH.

2) Si existe disfunción tiroidea esquemáticamente se puede considerar:

- Hipertiroidismo con tiroides ecográficamente homogénea: E de Graves?. Ac anti-tiroideos, Gammagrafía 
- Hipertiroidismo con nódulos: Gammagrafía tiroidea

- Hipotiroidismo con o sin nódulos: Considerar Ac anti-tiroideos, PAAF. Evaluar nódulos por UT

3) En condiciones de eutiroidismo definir los hallazgos ecográficos:

- Tiroides tamaño normal, homogénea: hallazgo normal

- Tiroides tamaño normal, micronódulos: hallazgo normal, salvo signos ecográficos de sospecha en algún nódulo

- Tiroides aumentada de tamaño, homogénea: bocio difuso?

- Tiroides multinodular aumentada de volumen, 20-40 ml: No configura aún BMN. Controlar, evaluar nódulos por UT

- Tiroides multinodular aumentada de volumen, $>40 \mathrm{ml}$ : Bocio Multinodular (BMN). Evaluar nódulos por UT. Considerar si es quirúrgico (volumen, plongeant, compresión, etc)

- Nódulo tiroideo solitario o su equivalente

4ㅇ) Aplicar PAAF en las siguientes situaciones:

- Cualquier NT en cualquier situación, número o tamaño que presente signos de sospecha de malignidad en la UT

- En el BMN solo en el o los NT que presenten signos de sospecha por UT ("nódulo discordante")

- NTS o su equivalente de mas de $10 \mathrm{mms}$ con o sin signos de sospecha

5) Evaluar PAAF según clasificación Bethesda, conductas mas probables:

\begin{tabular}{|l|c|c|}
\hline Categoría & Riesgo de malignidad (\%) & Conducta mas probable \\
\hline I. No diagnóstica o insatisfactoria & - & Repetir \\
\hline II. Benigna & $0-3$ & Seguimiento \\
\hline $\begin{array}{l}\text { III. Atipía sig incierto o lesión foli- } \\
\text { cular sig incierto }\end{array}$ & $5-15$ & Repetir \\
\hline $\begin{array}{l}\text { IV. Neoplasia folicular o presunta N } \\
\text { folicular }\end{array}$ & $15-30$ & $\begin{array}{c}\text { Confirmar por AP I/op. T. } \\
\text { Total }\end{array}$ \\
\hline $\begin{array}{l}\text { V. Presunción de cáncer } \\
\text { VI. Maligno }\end{array}$ & $60-75$ & Tiroidectomía total \\
\hline
\end{tabular}




\section{Ih) Indicaciones de cirugía en el Nódulo Tiroideo}

En opinión del autor es apropiado considerar por separado las indicaciones de cirugía en los NT en función de la entidad tiroidea mayor en la cual se inscriben los nódulos, clasificándolos en 3 grandes grupos:

- Nódulos tiroideos sin verdadero bocio

- Bocio Multinodular

- Nódulos tiroideos con hipertiroidismo

\section{Nódulos tiroideos sin verdadero bocio}

La mayor parte de los problemas diagnósticos y de pesquisa de malignidad se dan por lejos en esta categoría. En este grupo de pacientes se inscriben todos los nódulos de hallazgo incidental clínico o imagenológico únicos o múltiples en tiroides habitualmente de volumen total normal, y aquellas tiroides multinodulares de tamaño aumentado pero que por su volumen total, ausencia de autonomía demostrada de crecimiento y otros factores no configuran aún un diagnóstico preciso de BMN. Los BMN plantean problemas de decisión quirúrgica diferentes, y solo rara vez por la presencia de un nódulo maligno. En opinión del autor la multinodularidad como único factor aislado, aún en una tiroides moderadamente aumentada de volumen no es suficiente para hacer diagnóstico de BMN (8).

En este grupo mayoritario de pacientes las indicaciones de cirugía en el NT estan fuertemente influídas por los resultados de la citología por PAAF, tal como se ha descrito precedentemente. Sin embargo, es muy importante tener en cuenta que el resultado de la PAAF no es el único factor a tener en cuenta, sino que la indicación quirúrgica surge de la combinación de la citología con otros elementos a considerar, fundamentalmente la UT, síntomas y signos clínicos, el tamaño del nódulo, consideraciones estéticas y finalmente consideraciones cancerofóbicas. Cada paciente debe ser considerado en forma particular, manejando y balanceando con objetividad científica todos los elementos decisores en forma personalizada. En opinión del autor los rígidos y clásicos "algoritmos" no son aplicables para la totalidad de los pacientes, por cuanto no contemplan la individualidad de cada enfermo y por lo tanto si se utilizan debe hacerse con precaución. Se exponen a continuación los diferentes factores en un orden de mayor a menor en cuanto a su importancia y peso en la toma de decisión de cirugía en el NT (1,4,5,12,33,37,39):

1) Citología por PAAF, especialmente cat IV, V y VI del sistema Bethesda

2) Signos de sospecha en la UT

3) Síntomas y signos clínicos de sospecha u otros

4) Tamaño del nódulo y/o ritmo de crecimiento

5) Consideraciones estéticas

6) Cancerofobia 
Como las implicancias terapeúticas de la citología ya fueron consideradas extensamente analizamos el resto de los factores decisores.

\section{Signos de sospecha en la UT}

La UT, ademas de ser el recurso fundamental por el cual se seleccionan los nódulos para practicar la PAAF también debe tenerse en cuenta como factor decisor independiente. En un paciente con un NT puncionado y repuncionado, donde la citología reiteradamente aporta resultado no diagnóstico o de significado incierto, pero que mantiene firmes signos ecográficos de sospecha de malignidad, es claro que se impone la resección quirúrgica independientemente de otras consideraciones $(5,38,39,40,41,45,46)$.

\section{Síntomas y signos clínicos de sospecha u otros}

La presencia de síntomas y/o signos que sugieren infiltración tumoral y/o compresión significativa de estructuras vecinas, tales como disfonía, disfagia, disnea, dolor local u otros semejantes deben ser bien evaluados. Ellos pueden ser secundarios a infiltración tumoral por un nódulo relativamente pequeño o bien a compresión causada por un nódulo voluminoso o ambas cosas. En estos casos aún sin una clara confirmación de malignidad por PAAF, o bien con una UT no concluyente es claro que se impone la resección quirúrgica, probablemente precedida de una TAC para evaluar correctamente la situación locorregional $(1,2,4,5,12)$.

\section{Tamaño del nódulo}

Si bien el tamaño del NT no representa por sí mismo una indicación quirúrgica clara, es importante tener en cuenta que un NTS verdadero o su equivalente mayor a 3-4cms tiene una alta probabilidad de corresponder a una neoplasia tiroidea, y por lo tanto tiene un riesgo de malignidad de por lo menos el $10 \%$. Por otra parte el gran tamaño de un nódulo aún benigno condiciona muchas veces desplazamientos del eje visceral, a veces síntomas compresivos y grosera deformación cervical que por si solas pueden constituír una indicación quirúrgica. En relación al tamaño nodular el crecimiento progresivo de un nódulo, aún citológicamente benigno y mas aún si tiene elementos clínicos o en la UT de sospecha de malignidad, también constituye una indicación de resección quirúrgica. El resurgimiento de un quiste luego de varias PAAF evacuadoras, aún con citología benigna también encuadra dentro de una posible indicación quirúrgica si el quiste es voluminoso $(1,2,4,5,12,19)$.

\section{Consideraciones estéticas}

Si bien la estética en forma aislada no constituye un factor unánimemente aceptado para indicar una resección quirúrgica, la deformidad cervical antiestética causada por un NT va casi siempre asociada a un tamaño nodular considerable, eventualmente síntomas y también muchas veces crecimiento progresivo (1). 


\section{Cancerofobia}

La cancerofobia es una consecuencia negativa e inevitable de la epidemia diagnóstica de NT y del creciente diagnóstico incidental del micro CPT en el mundo entero $(1,5,6)$. El miedo a padecer un cáncer de tiroides de cualquier persona a la que se le ha detectado un NT es frecuentemente inducido por los propios médicos, incluso con cierta frecuencia por los propios endocrinólogos por distintas razones formativas. La cancerofobia no es una indicación científica aprobada para realizar una cirugía frente a un NT, de hecho el gran desafío que se tiene por delante es el de tratar de reducir al mínimo posible las intervenciones quirúrgicas innecesarias por patología benigna. Sin embargo, en las situaciones de indicación quirúrgica borderline la cancerofobia del paciente puede representar un factor que incline la balanza a favor de la cirugía.

\section{Bocio Multinodular}

Si bien el BMN no es el tema de que trata este relato, en la medida en que se caracteriza por la presencia de una gran cantidad de nódulos suele plantear problemas diagnósticos o dudas frente al eventual riesgo de malignidad de algunos de ellos. El tema BMN y cáncer de tiroides es tratado en detalle mas adelante en este relato, por lo cual aquí solo expondremos algunos lineamientos generales en forma esquemática (8):

- El diagnóstico de BMN solo se puede realizar cuando en un contexto de multinodularidad existe un volumen glandular total suficiente (en opinión del autor $>40 \mathrm{ml}$ ) y un ritmo de crecimiento que evidencia autonomía funcional de los nódulos.

- En estas condiciones estrictas de diagnóstico y en ausencia de factores que promueven la cancerogénesis, tales como antecedentes de irradiación cervical, cáncer familiar de tiroides, o procedencia de regiones de déficit endémico de yodo, la probabilidad de cáncer de tiroides mayor de $10 \mathrm{mms}$ en los nódulos es inferior al $1 \%$ o aún mucho menos.

- Tal como sucede en los pacientes con nódulos sin verdadero bocio, o incluso en estudios de autopsia sin enfermedad tiroidea, en el BMN existe una probabilidad de presencia de microcarcinoma papilar de tiroides inaparente y clínicamente no significativo de por lo menos el $10 \%$. La gran mayoría de estos tumores se diagnostican en forma incidental en la pieza de la tiroidectomía total practicada para el BMN, y tienen un excelente pronóstico. Es poco frecuente pero no imposible que con el auge de los métodos diagnósticos de imagen de alta resolución se diagnostique algún caso de microcarcinoma papilar inaparente en pacientes con BMN,que casi siempre se localiza en el parénquima internodular de los nódulos mayores del mismo. La gran mayoría de estos casos son de muy buen pronóstico.

- Los problemas fundamentales que plantea el BMN se refieren al crecimiento de la masa cervical, a la posibilidad de introducción en el mediastino, a la aparición de fenómenos compresivos y a la deformación grosera y antiestética del cuello. 
De todas estas consideraciones se desprende que en el BMN las indicaciones de cirugía solo rara vez surgen de la sospecha o presencia de cáncer de tiroides en alguno de los nódulos del mismo y que en realidad se apoyan habitualmente en argumentos resultantes del crecimiento de la masa bociosa y sus consecuencias.

\section{Nódulos tiroideos con hipertiroidismo}

El hipertiroidismo causado por nódulos tiroideos se observa fundamentalmente en dos situaciones: Algunos casos de BMN, donde la hiperfunción depende de uno o unos pocos nódulos autonomizados e hipersecretantes, y el adenoma tóxico, neoplasia tiroidea benigna y autónoma también hipersecretante.

El hipertiroidismo es una indicación muy clara de cirugía en NT. Los resultados de la cirugía superan con ventajas al tratamiento con I 131. Usualmente se practica una TT en el caso del BMN hipertiroideo y una simple lobectomía en el caso del adenoma tóxico, obteniendo una curación rápida, radical y definitiva de la enfermedad (43).

\section{Seguimiento de los pacientes que no se operan}

Como este relato esta dirigido a cirujanos interesa llamar a la reflexión a los colegas y enfatizar que la decisión mas fácil para el cirujano siempre es operar y que la mas difícil es encargarse del seguimiento de un paciente durante un período prolongado, asumiendo incluso la posibilidad de que optar por el seguimiento implica un mínimo riesgo de ignorar y diferir el diagnóstico de algún cáncer tiroideo. Sin embargo, las muy altas tasas de operaciones innecesarias por enfermedad tiroidea benigna acumuladas históricamente hacen que la conducta de la selección estricta de los pacientes para cirugía y un correcto seguimiento de los que no se operan se haya vuelto una imperiosa necesidad asistencial.

En el caso de los cánceres diferenciados de tiroides y especialmente en su forma mas común, el carcinoma papilar, es muy poco probable que un retraso en su diagnóstico por haber ingresado el paciente en un programa de seguimiento tenga alguna consecuencia negativa frente a la expectativa de curación de la enfermedad.

Los criterios y la táctica para el seguimiento se exponen a continuación $(1,4,5,37)$.

Los pacientes que no se operan son controlados periódicamente mediante anamnesis, examen físico y fundamentalmente mediante ultrasonografía tiroidea con doppler color. La ecografía tiroidea con doppler color o bien con power angio es el método idóneo de control y seguimiento de los NT que no son operados. Ella permite evaluar periódicamente el ritmo de crecimiento del nódulo, el eventual viraje de las características ecográficas del mismo con aparición de signos ecográficos de sospecha y/o la eventual aparición de adenopatías.

La periodicidad de la realización de UT esta establecida entre los 6 y los 12 meses. Generalmente se hace el primer control ecográfico a los 6 meses y si no existen cambios significativos y la PAAF previa era de benignidad el siguiente control puede realizarse a los 12 meses. En aquellos casos 
donde se considere que la presunción de benignidad no es tan clara se prefiere un seguimiento mas estricto, por lo cual es lícito repetir la UT cada 6 meses.

La duración del seguimiento no esta bien establecida, y debe ser personalizada para cada paciente en particular, influyendo en la misma la evolutividad de la "enfermedad nodular", el punto de partida desde el cual se inició el seguimiento (especialmente la categoría Bethesda), y el psiquismo de cada paciente así como sus sentimientos cancerofóbicos. En opinión del autor realizar una UT anual por un tiempo indefinido es un proceder seguro y costo efectivo si el cirujano se ajusta al resultado de la misma y evita prodigar otras intervenciones innecesarias tales como las PAAF "por las dudas." Algunos autores opinan que en el caso de NT benignos de tipo coloide con escaso componente celular en la PAAF (cat II) sería suficiente con un seguimiento anual por un período máximo de tres años (61).

Los criterios para repetición de la PAAF durante el seguimiento son los siguientes:

- A los tres meses en casos de muestra no diagnóstica (cat I) o bien atipía o lesión folicular de significado incierto (cat III). De esta forma el tiempo de espera permite la desaparición de las eventuales secuelas traumáticas, inflamatorias y/o hemorrágicas de la PAAF previa, que pueden alterar el nuevo citograma. Igual criterio se adopta cuando se opta por repetir en forma programada la PAAF en otras situaciones clínicas y/o categorías Bethesda cuando el cirujano desconfía de la calidad del informe previo.

- La reaparición de un quiste luego de su evacuación completa tiene indicación de repetir la punción-evacuación y nuevo estudio citológico, e incluso puede representar una indicación para cirugía.

- El crecimiento leve a moderado de un nódulo no es una indicación absoluta de repuncionar, por cuanto los nódulos benignos suelen crecer en un porcentaje significativo de los casos, sin embargo si el nódulo crece al menos un $50 \%$ en el intervalo de seguimiento debe ser repuncionado para descartar una neoplasia.

- En todas las demás situaciones la indicación de repetir la PAAF debe surgir de los hallazgos ecográficos durante el seguimiento (signos ecográficos de sospecha) o bien de la aparición de síntomas o signos clínicos de alarma. Es importante no prodigar punciones sin tener los estrictos criterios para su indicación que hemos mencionado, ya que dicha conducta no aumenta la eficacia diagnóstica, es costosa y no está exenta de complicaciones.

\section{Terapia supresiva con Tiroxina:}

La terapia supresiva de rutina con levo-tiroxina (T4) de los NT benignos en poblaciones sin déficit endémico en la ingesta de yodo no esta recomendada, por cuanto es totalmente ineficaz y puede causar complicaciones $(5,37)$. 


\section{Capítulo II}

\section{Introducción al Cáncer de Tiroides}

\section{Ila) Epidemiología y clasificación}

\section{Definición - Epidemiología}

La denominación genérica "Cáncer de Tiroides" (CT) incluye solamente a aquellos tumores malignos de estirpe epitelial originados en forma autóctona en las células epiteliales de la glándula tiroides. Dichas células son básicamente las células foliculares, las células parafoliculares o células $C$ y las células de Hürthle. Los tumores malignos comprendidos en esta definición son (32):

- Carcinomas diferenciados: Carcinoma papilar (CPT) y Carcinoma folicular (CFT)

- Carcinoma de células de Hürthle (CCH)

- Carcinoma medular (CMT)

- Carcinoma pobremente diferenciado (CPD)

- Carcinoma anaplásico (CA)

Los tumores malignos epiteliales tiroideos de origen metastático no constituyen estrictamente cánceres tiroideos por cuanto no son autóctonos de la glándula. El linfoma tiroideo y otros raros tumores tiroideos autóctonos de estirpe no epitelial también escapan a la definición y son habitualmente considerados por separado (32).

EI CT representa solo alrededor del $2 \%$ de todas las enfermedades tiroideas, siendo superado ampliamente por casi toda la gama de patología tiroidea corriente, es decir los nódulos de hiperplasia-involución benignos, los adenomas, el BMN y las diversas enfermedades tiroideas que cursan con disfunción glandular. A su vez dentro de la patología maligna en general el CT es un tumor poco frecuente, representando tan solo un $0,5-1 \%$ de todos los cánceres; sin embargo, si solo se consideran los cánceres endócrinos el CT se lleva un 90\% del total. La prevalencia en mujeres es 3-4 veces mayor que en hombres. La prevalencia del CT aumenta con la edad, observándose esquemáticamente un $5 \%$ de los casos en menores de 20 años, un $55 \%$ entre los 20 - 60 años y un $40 \%$ en mayores de 60 años (32). 
Sin embargo, el dato epidemiológico mas importante a considerar en la actualidad es que la incidencia del CT viene aumentando considerablemente en el mundo en los últimos años.

En Uruguay de acuerdo a los datos aportados por el Registro Nacional de Cáncer de la Comisión Honoraria de Lucha contra el Cáncer (CHLC) entre los años 1988 y 1997 la incidencia de CT para ambos sexos en conjunto fue de 4,8 casos / 100.000 hab / año, mientras que en el período 2005 2009 dicha incidencia aumentó a 9,12 casos / 100.000 hab / año, es decir prácticamente el doble (62, 63, 64).

En los EEUU el incremento registrado es aún mayor, pasando de 3,6 / 100.000 en 1973 a 8,7 / 100.000 en 2002, es decir un incremento de 2,4 veces (65). Considerando cifras absolutas la incidencia (nuevos casos / año) de casos de CT en los EEUU aumentó entre 2001 - 2011 de 20.000 a 48.000 (9). De acuerdo a datos de la American Cancer Society de los EEUU la estimación de nuevos casos para el 2014 será de casi 63.000, es decir mas del triple que en 2001; la tasa de incremento de diagnóstico entre los años 2006 - 2010 fue de 5,4\% anual en hombres y 6,5\% anual en mujeres (66). Notablemente, la tasa de mortalidad anual por CT ha permanecido estable entre los años 2006 2010 en los EEUU, siendo similar en hombres y mujeres, del orden de 0,5 / 100.000 hab / año (66).

Existe consenso entre los diferentes autores en que este gran incremento registrado en los últimos años se debe fundamentalmente a un incremento en la tasa de detección de pequeños tumores clínicamente inaparentes o microcarcinomas, especialmente papilares, debido al uso cada vez mas extendido de la ultrasonografía tiroidea. Se trata de una consecuencia inevitable de la verdadera epidemia de diagnóstico de nódulos tiroideos, aspecto que ya hemos considerado precedentemente $(6,7,9,10,32,65,66)$.

La influencia epidemiológica del CT como causa de muerte en la población general es escasa y ha permanecido muy estable desde hace varios años, promediando tanto en Uruguay como en los EEUU unos 0,5 fallecidos / 100.000 hab / año. Dentro de las muertes por cáncer el CT representa 0,3\% de todas las muertes por cáncer en la mujer y $0,1 \%$ en el hombre $(32,66)$.

\section{Clasificación}

Los tumores epiteliales autóctonos de la glándula tiroides, es decir los cánceres de tiroides propiamente dichos se pueden clasificar de la siguiente manera $(32,67)$ :

- Carcinoma Papilar (CPT): $70-80 \%$

- Carcinoma Folicular (CFT): $10-20 \%$

- Carcinoma de Células de Hürthle (CCH): 1 - 3\%

- Carcinoma Pobremente Diferenciado (CPD): Raro

- Carcinoma Anaplásico (CA): 5 - 10\%

- Carcinoma Medular (CMT): 1 - 10\%

Sin embargo, esta distribución porcentual se modifica sustancialmente de acuerdo al grado de ingesta de yodo de la población en cuestión. Es así que en las regiones o países donde existe defi- 
ciencia endémica de yodo el porcentaje de CFT y de CA aumenta significativamente,mientras que en las regiones donde la ingesta de yodo es suficiente o excesiva (como Uruguay y muchos otros países occidentales) el CPT representa prácticamente el $90 \%$ de todos los cánceres de tiroides $(32,67)$. EI CMT es mas frecuente en occidente (3-10\%) que en Japón (1-3\%).

\section{IIb) Cáncer Diferenciado de Tiroides}

El CPT y el CFT son frecuentemente considerados como "Cánceres Diferenciados de Tiroides", entendiendo por tal tumores de baja o mediana malignidad cuyas células remedan a grandes rasgos la forma y disposición de las células foliculares normales, conservando gran parte de sus características biológicas y funcionales. Es así que estas células tumorales mantienen en grados variables pero siempre presente la capacidad de las células normales de captar yodo y de responder a los estímulos de TSH, propiedades que se utilizan para desarrollar tratamientos no quirúrgicos de gran eficacia tales como la administración de yodo radiactivo y la hormonosupresión con tiroxina (32). De cualquier manera el CPT y el CFT son tumores bien diferentes, con comportamiento biológico y pronóstico también diferentes, de tal forma que su agrupamiento como "Cánceres Diferenciados" solo tiene un interés descriptivo y académico.

\section{Carcinoma papilar}

Como se pretende que el contenido de este relato sea esencialmente práctico, en esta sección solo se presentarán de forma resumida las principales características del CPT que determinan la conducta terapeútica y el pronóstico $(32,67,68,69)$.

\section{Aspectos generales}

EI CPT es el tumor maligno mas frecuente de la glándula tiroides, representando alrededor del $70-80 \%$ de los casos en series multicéntricas, alrededor del $50 \%$ en regiones con severa deficiencia endémica de yodo, y casi el $90 \%$ o mas en los países con ingesta suficiente o excesiva de yodo en la dieta, tal como es el caso de Uruguay.

El CPT predomina netamente entre los 30 - 50 años de edad, es mucho menos frecuente por encima de los 45 años y es prácticamente el único tumor tiroideo que se observa por debajo de los 20 años y en niños.

El CPT es el típico tumor que se observa en aquellos casos de cáncer tiroideo secundario a exposición a radiaciones. En los sobrevivientes de Hiroshima y Nagasaki la incidencia de cáncer de tiroides, básicamente CPT, aumentó 1750 veces, en tanto que luego del desastre de Chernobyl la incidencia de CPT en Bielorrusia aumentó 100 veces en niños y 60 veces en adultos.

Tanto los cánceres tiroideos que se presentan como "incidentalomas" en estudios de imagen, como los cánceres incidentales diagnosticados en piezas de tiroidectomía y los cánceres ocultos 
detectados en estudios de autopsia son en su gran mayoría CPT, especialmente pequeños CPT de menos de $10 \mathrm{mms}$, también conocidos como "microcarcinomas".

La gran mayoría de los casos se presentan de forma esporádica, pero entre un $3-5 \%$ de los CPT afectan a familias, raramente como única patología y mas frecuentemente en asociación con otras enfermedades tales como la Poliposis Familiar, Síndrome de Gardner o Cowden.

\section{Anatomía patológica}

EI CPT presenta las siguientes características anatomopatológicas:

- Citología típica, con células de núcleos redondos u ovalados de aspecto vacío o en vidrio esmerilado, con pseudonucleolos y una indentación típica que los atraviesa.

- Presencia de papilas, que pueden faltar en la variante folicular

- Cuerpos de psammoma, que son papilas infartadas y calcificadas

- Microcalcificaciones

- Quistificación

- Multicentricidad de $20-80 \%$

- Inmunohistoquímica positiva para Tiroglobulina ( $\mathrm{Tg}$ ) y Citoqueratina

Existen diferentes variantes anatomopatológicas del CPT, algunas de las cuales presentan un interes particular en su conocimiento:

- Variante folicular:Se caracteriza por la ausencia total o casi total de papilas, por lo cual el diagnóstico debe fundamentarse en la citología; puede plantear problemas diagnósticos en la citología por PAAF y también en la biopsia intraoperatoria.

- Variante de células altas, de células columnares y esclerosante difusa: Son poco frecuentes pero de peor pronóstico. La de células altas afecta comúnmente a mujeres añosas, y la esclerosante difusa a niños.

- Variante oncocítica o de células oxífilas. Se comporta en forma similar a los $\mathrm{CCH}$, por lo cual se clasifican como tales y no como CPT.

\section{Comportamiento biológico y pronóstico}

En términos generales el CPT es un tumor de crecimiento lento y baja o mediana agresividad, lo cual se refleja en una tasa de sobreviva a 20 años mayor al 90\%. Sin embargo, algunos tipos histológicos, algunos grupos de pacientes de riesgo y en unos pocos casos sin características especiales, el CPT puede mostrar un comportamiento mas agresivo e incluso excepcionalmente ser causa de muerte.

La extensión extratiroidea (T4 en la clasificación TNM) se observa promedialmente en un 8-10\% de los casos, observándose mas frecuentemente en pacientes añosos, especialmente en la variedad 
de células altas, que se observa sobre todo en viejos. Constituye un elemento de mal pronóstico en los pacientes mayores de 45 años (estadio III de la clasificación TNM).

La diseminación linfática es característica del CPT, ya que se trata de un tumor extremadamente linfófilo. Sin embargo, la mayor parte de las veces se trata de micrometástasis clínicamente no evidentes, cuya presencia ha sido bien demostrada por los autores japoneses, grandes defensores de los vaciamientos profilácticos. La presencia de ganglios clínicamente evidentes se observa solo en el $10-20 \%$ de los casos al momento del diagnóstico. La probabilidad de metástasis ganglionares sean o no evidentes guarda relación con el tamaño tumoral de acuerdo al siguiente esquema:

- CPT menor a $5 \mathrm{mms}$ (microcarcinoma): $10 \%$

- CPT de 5 a 10 mms (microcarcinoma): 30 - 50\%

- CPT de mas de $15 \mathrm{mms}: 90 \%$

A pesar de la alta frecuencia de metástasis ganglionares, aún si se practican tiroidectomías sin vaciamientos profilácticos la tasa de recidiva ganglionar es baja, del orden de solo $5-20 \%$. Es probable que el tratamiento adyuvante con yodo radiactivo y la hormonosupresión con tiroxina sean las responsables de esta baja tasa de recidivas ganglionares, pero tampoco puede descartarse la falta de potencial biológico evolutivo de las micrometástasis ganglionares ocultas en muchos pacientes. Tampoco ha sido posible demostrar que los vaciamientos ganglionares profilácticos hayan mejorado la sobrevida y el pronóstico en general del CPT. Los resultados de los vaciamientos centrales profilácticos para bajar la tasa de recurrencias ganglionares no son del todo concluyentes y han sido opacados por la alta morbilidad de la técnica a nivel del compartimento central del cuello. Mas aún, el auge en los últimos años del vaciamiento ganglionar central profiláctico de rutina en el CPT viene decayendo francamente en las publicaciones mas recientes por sus pobres resultados oncológicos, su baja costo - efectividad y su alta morbilidad $(70,71,72)$. La influencia de las metástasis linfáticas en el deterioro de la sobreviva se aprecia sobre todo por encima de los 45 años, y muy especialmente en los pacientes mas añosos.

Las metástasis hematógenas en el CPT son relativamente raras, con una incidencia global de $2-10 \%$ de los casos, y se ubican predominantemente en el pulmón y en segundo lugar en el hueso. Son excepcionales en los microcarcinomas, aunque existen casos bien documentados, incluso con desenlace fatal. Son muy poco frecuentes por debajo de los 45 años, y cuando aparecen definen el estadio II de la clasificación TNM para este grupo etario.

Otros factores que condicionan un peor pronóstico del CPT son la edad mayor a 45 años, especialmente mayor a 60 años, y la presencia de subtipos histológicos mas agresivos, tales como la variedad de células altas, de células columnares y la esclerosante difusa.

\section{Formas de presentación clínica del CPT}

Nódulo tiroideo solitario palpable: Esta forma de presentación clínica era la predominante (75$80 \%$ de los casos) antes de la epidemia diagnóstica de nódulos tiroideos que ha desencadenado el 
uso extendido de la moderna ecografía doppler de alta resolución, con un aumento notorio del diagnóstico imagenológico de pequeños CPT o microcarcinomas no palpables $(5,6,7,9$,$) .$

Microcarcinoma: Representaba hasta hace pocos años solo un $20-25 \%$ de las formas de presentación del CPT, pero en el momento actual es el responsable directo de un aumento al doble o triple de la incidencia de CT, por lo cual se esta convirtiendo en la forma de presentación mas frecuente de los últimos tiempos $(5,6,7,9,10,32,65,66)$.

Cáncer papilar oculto o incidental: Son también frecuentemente microcarcinomas, y se encuentran promedialmente en el $10 \%$ de las piezas de tiroidectomía resecadas por patología benigna y también promedialmente en el $10 \%$ de las tiroides de estudios de autopsia de cadáveres sin enfermedad tiroidea conocida, aunque han sido publicadas tasas de mas de $35 \%(1,3)$.

Nódulo tiroideo con adenopatías palpables: Representa un 10-20\% de los casos, las adenopatías se pueden localizar en el compartimento central del cuello o en el lateral homolateral, con una probabilidad aproximadamente similar para ambos; las adenopatías contralaterales son muy poco frecuentes, y se ven en tumores agresivos que ya han metastatizado los compartimentos central y lateral homolateral.

Adenopatía palpable con primitivo oculto: Se observa en menos del $10 \%$ de los casos, comprende dos situaciones disímiles, la mas frecuente que es primitivo oculto pero detectable por imágenes y/o anatomía patológica, o bien primitivo indetectable ni siquiera por estudios de anatomía patológica en la pieza de tiroidectomía. En esta última y rara situación a veces es posible detectar en la pieza una pequeña cicatriz fibrosa con cuerpos de psammoma como única secuela de un microcarcinoma que involucionó totalmente. También debe debe tenerse en cuenta la posible presentación como "quiste lateral de cuello", que corresponde en realidad a metástasis ganglionar quistificada de CPT; la quistificación de las metástasis ganglionares del CPT se puede observar en grados variables hasta en el $70 \%$ de los casos $(32,73)$.

Con extensión extratiroidea: 5 - 15\% de los casos, se observa sobre todo en mujeres añosas, frecuentemente con la variedad de células altas.

Con metástasis hematógenas: 1 - 5\% de los casos en el momento del diagnóstico, también es mas común en pacientes añosos y/o con variantes mas agresivas.

\section{Carcinoma folicular}

Siguiendo los mismos criterios de practicidad del presente relato a que hacíamos referencia para el CPT, en esta sección solo se presentarán de forma resumida las principales características del CFT que determinan la conducta terapeútica y el pronóstico $(32,67,68,69)$.

\section{Aspectos generales}

El CFT es el segundo tumor maligno mas frecuente de la glándula tiroides en aquellas áreas geográficas con ingesta suficiente o excesiva de yodo en la dieta. Se incidencia viene bajando claramente en los países occidentales en general, siempre que no exista déficit endémico de yodo. En estas regiones representa un $5 \%$ o menos $(2-5 \%)$ de todos los cánceres de tiroides, en tanto que en 
las poblaciones afectadas por déficit endémico de yodo puede llegar a un 25-50\%. Esta claramente demostrado que la suplementación con yodo de estas poblaciones deficitarias disminuye drásticamente la incidencia de CFT.

La distribución por edades es claramente diferente a la del CPT, con un predominio neto entre la 5a y sexta década de la vida, siendo su promedio de edad de 60 años, vs 40 años para el CPT. La distribución por sexos es similar, predomina en mujeres, con una relación de 2-3/1 con respecto a los hombres.

Los antecedentes de irradiación cervical no tienen ninguna relación con el CFT, aunque sí con los adenomas foliculares benignos; se trata de una diferencia sustancial con el CPT.

Su forma de presentación como microcarcinoma oculto (estudios de autopsia), incidental (piezas de tiroidectomía), o incidentaloma (estudios de imagen) es poco frecuente. Se encuentran promedialmente un $1 \%$ de microcarcinomas foliculares en autopsias, vs hasta un $35 \%$ para los microcarcinomas papilares. Como veremos mas adelante el significado biológico de la detección de microcarcinomas foliculares o bien de células de Hürthle es bien diferente que para los papilares, y la mayoría de los autores concuerdan en que deben ser tratados como tumores con potencial agresividad.

Los carcinomas de células de Hürthle $(\mathrm{CCH})$ son clasificados por la OMS y por algunos autores como variantes del CFT, pero la realidad es que el $\mathrm{CCH}$ es un tumor en general mas agresivo que el CFT, con patrones de diseminación diferentes, pronóstico diferente y con una muy escasa o nula capacidad de captar yodo o de ser inhibido mediante hormonosupresión con tiroxina. Por todo ello en opinión de la mayoría de la literatura y del propio autor de este relato no debe ser incluído en el grupo de "carcinomas diferenciados de la tiroides" y sí debe clasificarse y estudiarse por separado.

\section{Anatomía patológica}

Se trata de un tumor originado en las células foliculares tiroideas, con una estructura que remeda los folículos acinares glandulares, es decir que es un verdadero adenocarcinoma. Su grado de diferenciación puede variar desde una estructura de folículos tiroideos de aspecto prácticamente normales hasta un patrón de crecimiento sólido y sin folículos. La variante folicular del CPT y los CCH no deben ser incluídos dentro de los CFT. Para que un tumor folicular maligno con células de Hürthle pueda ser clasificado como $\mathrm{CCH}$ debe estar constituído por un mínimo de $75 \%$ de estas células; porcentajes inferiores al $50 \%$ se clasifican comoCFT.

Independientemente de la variante morfológica de CFT que se considere los criterios para establecer malignidad son solo dos: demostrar invasión capsular y/o invasión vascular en los cortes histológicos convencionales. Se trata de criterios fundamentales para establecer la diferencia entre un CFT y un simple adenoma folicular.

La multicentricidad y bilateralidad es poco común, del orden del $10 \%$, otro aspecto bien diferente en comparación con los CPT, donde oscila entre el $20-80 \%$ de los casos.

Los CFT se clasifican en dos grandes variantes de pronóstico radicalmente diferente: el CFT mínimamente invasivo o encapsulado y el CFT ampliamente invasivo o angioinvasor. 


\section{CFT mínimamente invasivo}

Representa afortunadamente un $90 \%$ de los casos. Se trata de un tumor encapsulado de arquitectura fundamentalmente microfolicular, indistinguible a simple vista de un adenoma folicular. El diagnóstico citológico o por biopsia intraoperatoria por congelación es habitualmente imposible. Los criterios de malignidad son generalmente muy sutiles, y se basan en la demostración de uno o mas focos de invasión capsular "en reloj de arena" o bien en una angioinvasión limitada de alguna o algunas vénulas subcapsulares.

El CFT mínimamente invasivo se presenta habitualmente como un tumor pequeño y de baja agresividad. En general tiene un buen pronóstico, su mortalidad a 20 años es de $3-5 \%$.

\section{CFT ampliamente invasivo}

Constituye un $10 \%$ de los casos. Se trata de tumores mas grandes, a veces con invasión extratiroidea, no encapsulado o solo parcialmente encapsulado,con márgenes infiltrativos, y fundamentalmente con una amplia angioinvasión, que es el elemento fundamental que define a esta variante. Es un tumor habitualmente muy celular, que puede contener áreas sólidas, pero en general casi siempre se reconocen microfolículos en proporción variable. La ausencia de folículos debe orientar a otra variedad de cáncer tiroideo, como el carcinoma pobremente diferenciado (CPD) o bien el carcinoma anaplásico (CA). El diagnóstico intraoperatorio por congelación es en general mas fácil, diferenciando claramente estos tumores de los adenomas foliculares.

El CFT ampliamente invasivo es un tumor agresivo, que desarrolla diseminación metastásica hematógena en el $80 \%$ de los casos, con una mortalidad de $50 \%$ a 10 años.

\section{Comportamiento biológico y pronóstico}

El CFT ampliamente invasivo es un tumor de clara agresividad y mal pronóstico, pero la variedad mínimamente invasiva muestra un comportamiento mas indolente. Sin embargo, en términos generales se acepta que incluso el CFT mínimamente invasivo tiene un comportamiento biológico mas agresivo que el CPT, y si se comparan ambos tumores dentro de la franja etaria donde predomina el CFT, es decir los 60 años, la mortalidad por CFT es el doble que la del CPT. No esta claro si la diferencia pronóstica se debe a una biología diferente o bien si solo surge de comparar tumores con diferente prevalencia por edad y donde es bien conocido que la edad menor a 45 años es un factor de mejor pronóstico para el cáncer diferenciado en general.

La tasa de sobrevida para la variedad mínimamente invasiva es comparable en general a la del CPT, superando el $90 \%$ a 20 años, sin embargo para la variedad angioinvasora es de solo $50 \%$ a 10 años.

El tamaño tumoral del CFT que se presenta como un nódulo tiroideo solitario ( $90 \%$ de los casos) es promedialmente de $4 \mathrm{cms}$, claramente diferente a la alta incidencia de microcarcinoma del CPT. La invasión extracapsular se ve en $10-25 \%$ de los casos de la variedad angioinvasora. 
La diseminación linfática es infrecuente, observándose solo en 6-10\% de los casos, generalmente en asociación con diseminación hematógena y/o invasión extratiroidea.

La diseminación hematógena se observa en el 15-20\% de los casos, siendo las metástasis mas frecuentes las pulmonares, óseas, hepáticas y del sistema nervioso central en ese orden.

\section{Formas de presentación clínica del CFT}

Nódulo tiroideo solitario palpable: $90 \%$ de los casos; en la variedad mínimamente invasiva es en general un tumor mas pequeño e intratiroideo,mientras que en la variedad angioinvasora se trata de tumores mas grandes. El promedio global de tamaño es de $4 \mathrm{cms}$.

Metástasis hematógenas: 15 - 20\% de los casos, pueden representar la primera manifestación de la enfermedad, incluso con primario tiroideo poco evidente a la palpación del cuello. Raramente pueden ser secundarias a la variedad mínimamente invasiva.

Formas raras de presentación: microcarcinoma y tumor con adenopatías palpables son formas raras de presentación, globalmente la extensión extratiroidea también es poco frecuente. El CFT con hipertiroidismo es raro, la hiperfunción puede depender del propio tumor o bien y mas frecuentemente de sus metástasis. 


\section{Capítulo III}

\section{El problema del microcarcinoma}

\section{IIIa) Definición, generalidades, alcance}

El término "microcarcinoma" se refiere a un tumor tiroideo de tamaño menor o igual a 10 $\mathrm{mms}$, independientemente de su tipo histológico.

Ya se ha hecho referencia en secciones anteriores al problema del diagnóstico incrementado de nódulos tiroideos y de microcarcinomas papilares en los últimos tiempos como consecuencia del uso liberal de diferentes técnicas de imágenes. También se hizo referencia acerca de que el significado biológico y pronóstico del microcarcinoma papilar (micro CPT) es todavía incierto y que se presenta en la mayoría de los casos como un tumor indolente muchas veces ignorado $(9,10,32)$. Parece claro que el microcarcinoma papilar merece un análisis especial que permita elaborar pautas prácticas y contemporáneas de conducta para lograr la mejor comprensión del problema y optimizar el encare terapéutico del mismo.

La pregunta lógica que surge en este sentido es si se debe circunscribir la discusión exclusivamente al micro CPT o si también es válido y útil incluír en la misma a los restantes y eventuales microcarcinomas que pudieran detectarse en las restantes variedades histológicas del cáncer tiroideo.

En este sentido parece claro que tanto el carcinoma medular (CMT), como el carcinoma pobremente diferenciado (CPD) o el carcinoma anaplásico (CA), solo por excepción se podrían presentar como microcarcinomas, y aún en dicho hipotético caso tendrían un nivel de agresividad y potencial de metastatización tan importantes que carecería de sentido considerar en estos casos alguna medida mas conservadora de tratamiento o seguimiento (50).

Sin embargo, en el caso del carcinoma folicular (CFT) y del carcinoma de células de Hürthle $(\mathrm{CCH})$, tumores a medio camino en cuanto a agresividad se refiere entre el CPT y las restantes variedades mas agresivas mencionadas, podría eventualmente caber alguna discusión en este sentido.

Tanto el micro CFT como el micro CCH son formas de presentación poco frecuentes de estos tumores, por lo cual no abundaban hasta hace poco en la literatura publicaciones de peso estadístico suficiente como para establecer comparaciones con el micro CPT.

Sin embargo, recientemente Kuo y col (74) publicaron una extensa serie de casos recopilados entre los años 1988 y 2009, compuesta por 564 pacientes, de los cuales 371 tenían un micro CFT 
y 193 un micro CCH. Esta serie fue estudiada con rigor estadístico y confrontada con una serie de 22.174 casos de micro CPT recopilados durante el mismo período. Este interesante y reciente estudio demostró que los pacientes con microcarcinomas no papilares (CFT y CCH) tuvieron una probabilidad de metástasis extracervicales 8 veces mayor que para los micro CPT y que la tasa de supervivencia a 10 años fue de $95,4 \%$ para los tumores no papilares y de 99,3\% para los papilares. Luego de realizados los ajustes estadísticos correspondientes se comprobó que tanto la histología folicular como la de células de Hürthle representaron un factor de riesgo independiente de incremento de la mortalidad. Todos los resultados fueron estadísticamente significativos. Las conclusiones del estudio fueron que si bien los microcarcinomas CFT y CCH son raros comparados con los mico CPT, se presentan como mas propensos a desarrollar metástasis y que comprometen la sobreviva en forma significativa.

Se puede concluír que solo el micro CPT merece un análisis detenido en cuanto a la posibilidad de realizar tratamientos Menos agresivos en función que la mayoría de las veces, aunque no siempre, se presenta como un tumor de baja o casi nula agresividad. Cualquier otra histología diferente a la papilar en un microcarcinoma no debería ser considerada para recibir un tratamiento conservador y tendría que encararse como cualquier otro tumor de la misma estirpe pero de un tamaño mayor.

\section{IIIb) Microcarcinoma papilar de tiroides}

\section{Definición y clasificación}

El micro CPT es en la actualidad el tipo mas común de cáncer tiroideo que es diagnosticado, siendo definido por la Organización Mundial de la Salud como un carcinoma papilar con un tamaño igual o inferior a $10 \mathrm{mms}$ (75). Es diagnosticado de diversas formas, ya sea en forma incidental en piezas de tiroidectomía por patología benigna, en forma incidental en estudios de tiroides de autopsias de sujetos sin enfermedad tiroidea conocida, o bien mas recientemente en forma "no incidental" en el sujeto en vida y con su tiroides puesta al ser detectado a través de la generosa expansión del uso de imágenes cervicales (especialmente la ultrasonografía) y confirmado por PAAF eco-guiada. Esta última forma de detección ha sido la responsable como ya hemos referido del aumento al triple de la incidencia de cáncer tiroideo en la mayoría de los países occidentales $(6,7,9,10,32,65,66)$. Como esta forma de detección por imágenes de un nódulo-cáncer es frecuentemente llamada "incidentaloma" por cuanto se detecta en un sujeto sin nódulo conocido y/o palpable, puede generar confusión con la forma "incidental" detectada en piezas de tiroides quirúrgicas o cadavéricas.

A los efectos de clarificar la clasificación del micro CPT se prefiere denominar "incidental" a los micro CPT encontrados casualmente en piezas de tiroidectomías o en tiroides cadavéricos y "no incidental" a los detectados en vida y con la tiroides en su lugar mediante estudios de imagen y PAAF ecoguiada (75). 
- Incidental

- Piezas de tiroidectomía en enfermedad benigna

- Tiroides cadavéricas en ausencia de enfermedad tiroidea conocida

- No incidental

- Detección por estudios de imagen

- Raramente nódulo palpable

- Confirmación por PAAF eco-guiada

\section{Epidemiología}

La prevalencia del micro CPT incidental en estudios de tiroides de autopsia varía significativamente de acuerdo a la fuente de origen del estudio, lugar geográfico, exposición a radiación, ingesta de yodo y fundamentalmente en función del número de cortes realizados y su espesor. Cortes mas finos y numerosos generan un importante aumento del porcentaje de hallazgo de micro CPT en una pieza de autopsia. En el cuadro siguiente se resume la prevalencia del micro CPT incidental cadavérico de diferentes fuentes citadas por Drucker (75).

\begin{tabular}{|c|c|c|c|}
\hline Autor & Año & País & \% Micro CPT \\
\hline Yamamoto & 1990 & Japón & 11,3 \\
\hline Mitselou & 2002 & Grecia & 5,6 \\
\hline Harach & 1985 & Finlandia & 35,6 \\
\hline Lang & 1988 & Alemania & 6 \\
\hline Nishyama & 1977 & EEUU & 13 \\
\hline Sampson & 1974 & EEUU & 5,7 \\
\hline Fukunaga & 1975 & Varios países & 11,9 \\
\hline
\end{tabular}

La prevalencia del micro CPT incidental en piezas de tiroidectomía resecadas por enfermedad tiroidea benigna es también variable pero significativa en varios estudios publicados:

Fink y col (76) reportó un hallazgo de micro CPT sobre 425 piezas de tiroidectomía por enfermedad benigna resecadas en forma consecutiva entre 1991 y 1995 de 16,7\%.

Pelizzo y col (77) estudió 277 piezas de tiroidectomía consecutivas con diferentes diagnósticos de enfermedad benigna con el siguiente hallazgo discriminado de micro CPT: 
- BMN eutiroideo: $17,1 \%$

- Adenoma tóxico: $2,5 \%$

- Enfermedad de Graves: 5,7\%

- BMN tóxico (22/277): 0\%

Miccoli y col (78) estudiaron 998 casos de pacientes resecados por enfermedad tiroidea benigna, encontrando 104 casos de cáncer tiroideo incidental (10,4\%), 99 fueron casos de CPT (95\%) de los cuales el $75 \%$ fueron microcarcinomas definidos en este estudio como tumores de $<2 \mathrm{cms}$. La prevalencia discriminada según la patología benigna de base fue la siguiente:

- BMN eutiroideo: $13,8 \%$

- BMN tóxico: $8,2 \%$

- Enfermedad de Graves: 8,7\%

La prevalencia del micro CPT no incidental diagnosticado principalmente por estudios de imagen y PAAF eco-quiada ha ido en aumento en los últimos años, en relación directa con el uso extendido de la imagenología de alta resolución y el sobrediagnóstico de nódulos tiroideos insospechados como ya ha sido analizado anteriormente. Este aumento de la prevalencia del micro CPT no incidental es el responsable del aumento al triple de la incidencia de cáncer de tiroides en la mayor parte del mundo $(6,7,9,10,32,65,66,75)$.

De acuerdo a Baloch y Li Volsi (79) con los datos proporcionados por los estudios de autopsia, los proporcionados por los estudios de anatomía patológica en piezas de resección por patología benigna y la gran tasa de aumento de detección de micro CPT no incidentales se puede concluír que es altamente probable que hasta $1 / 3$ de la población adulta mundial sea portadora de un micro CPT en su tiroides, constituyendo un gran problema asistencial que debe dilucidarse.

\section{Comportamiento biológico del micro CPT}

Diversos estudios han sido realizados para establecer el significado biológico del micro CPT, su pronóstico vital y en última instancia cual debería ser el mejor encare terapéutico para esta enfermedad.

Roti y col (80) realizaron un metaanálisis en el cual se incluyeron un total de 9379 pacientes, encontrando en términos generales resultados que revelan un buen pronóstico para la mayoría de los pacientes con micro CPT. Las metástasis en el momento del diagnóstico se observaron en el 0,37\% de los pacientes, las metástasis durante el seguimiento en el $0,27 \%$ y la recurrencia local y/o linfática en el $2,4 \%$, siendo la mortalidad total de la serie de solo $0,34 \%$. Estos autores determinaron con sig- 
nificación estadística que la presencia de un tumor evidente, es decir no incidental, multifocalidad, compromiso ganglionar y/o metástasis al momento del diagnóstico se relacionaron con una mayor probabilidad de recurrencia.

Noguchi y col (81) estudiaron 867 casos de micro CPT con un promedio de seguimiento de casi 13 años, encontrando evasión extratiroidea en el 10\% de los casos, metástasis ganglionares en el $10 \%$ y multifocalidad en el $10 \%$, pero las tasas de recurrencia y mortalidad fueron respectivamente de solo $1,4 \%$ y $2,4 \%$.

Pellegriti y col (82) estudiaron 299 casos de micro CPT que tuvieron indicadores de peor pronóstico, con $20 \%$ de evasión extratiroidea, 30\% de metástasis ganglionares, 30\% de multifocalidad y $3 \%$ de metástasis hematógenas, todo lo cual se asoció con una tasa de recurrencia y/o persistencia de $26 \%$. La mortalidad a 4 años fue de $0 \%$, pero evidentemente representa un seguimiento demasiado corto en este sentido.

Según Baloch y Li Volsi (79) alrededor del 10\% de los micro CPT pueden presentar metástasis ganglionares y/o recurrencias de la enfermedad.

De estos estudios y muchos otros se desprende que no todos los micro CPT tienen un comportamiento benigno y que existe evidencia que parece indicar que factores tales como multifocalidad, extensión extratiroidea, ganglios positivos, metástasis hematógenas y presentación no incidental del tumor se asocian con un peor pronóstico. Como las distintas series tienen proporciones variables de tumores incidentales y no incidentales interesa determinar si existen diferencias pronósticas entre ambas formas de peresntación.

Ortiz y col (83) estudiaron retrospectivamente una serie de micro CPT de 83 pacientes, de los cuales $36 \%$ fueron tumores no incidentales y $64 \%$ incidentales. Los resultados del estudio se resumen en la siguiente tabla:

\begin{tabular}{|c|c|c|}
\hline Factor pronóstico & No incidental & Incidental \\
\hline Extensión extratiroidea & Similar & Similar \\
\hline Multifocalidad & Similar & Similar \\
\hline Metástasis ganglionares & $53 \%$ & 0 \\
\hline Recurrencias & $17 \%$ & 0 \\
\hline Metástasis hematógenas & $10 \%$ & 0 \\
\hline Mortalidad & $3,3 \%$ & 0 \\
\hline
\end{tabular}

El estudio encontró claramente un peor pronóstico para los tumores no incidentales, con mas metástasis, mas recurrencias y mayor mortalidad.

Dunki-Jacobs y col (84) estudiaron 196 CPT de los cuales 96 fueron micro CPT (casi 50\%). 56 (58\%) de estos micro CPT fueron incidentales, mientras que 40 (42\%) fueron no incidentales. La tasa de multifocalidad fue similar entre ambos grupos, pero las metástasis ganglionares ocurrieron solo 
en el 3,6\% de los tumores incidentales vs un $35 \%$ de los no incidentales; la extensión extratiroidea también fue mas frecuente en el grupo no incidental, $12,5 \%$ vs $3,6 \%$, sugiriendo una mayor agresividad biológica.

Lombardi y col (10) estudiaron una importante serie de micro CPT, compuesta por 933 casos sobre 2220 tiroidectomías realizadas entre 2002 y 2007 en Italia. 75\% de los micro CPT fueron incidentales, vs $25 \%$ no incidentales. Del análisis estadístico de la serie surgen como factores independientes de peor pronóstico del micro CPT la condición de no incidental, la extensión extratiroidea, la multifocalidad y los ganglios positivos. Los tumores incidentales se mostraron como tumores de bajo riesgo, en concordancia con los resultados de muchas otras series. El corto seguimiento de los pacientes no permitió extraer conclusiones en cuanto a recurrencias y sobrevida.

En suma, existe evidencia suficiente que demuestra que los micro CPT incidentales que no reúnen otras condiciones peyorativas tales como extensión extratiroidea, multifocalidad,histología desfavorable, o bien ganglios metastáticos o metástasis a distancia, que por otra parte son poco frecuentes en esta variedad, tienen un excelente pronóstico y los pacientes solo necesitan un seguimiento poco intensivo luego de una resección conservadora de la tiroides.

Por otra parte los tumores no incidentales se presentan mas frecuentemente con una mayor probabilidad de presencia de las condiciones peyorativas mencionadas y en muchas series con una mayor probabilidad de recurrencia y mortalidad, lo cual justificaría un tratamiento y seguimiento mas agresivos.

\section{Seguimiento sin cirugía en el micro CPT no incidental?}

El rápido aumento de la incidencia de cáncer de tiroides de bajo riesgo en el mundo se debe principalmente al "descubrimiento" de un gran reservorio de enfermedad subclínica micropapilar de buen pronóstico en la población, detectada por la mayor utilización de los estudios de imagen (85), especialmente la ultrasonografía, la TAC y el PET Scan, tal como ha sido referido en este relato con anterioridad $((6,7,9,10,32,65,66,75)$.

La apertura de este reservorio oculto de enfermedad subclínica plantea la duda acerca de si estos tumores "no incidentales" tienen realmente un peor pronóstico que los detectados incidentalmente en piezas de tiroidectomía, o simplemente son la misma enfermedad enfrentada a una mayor capacidad diagnóstica del sistema asistencial.

En este sentido los autores japoneses fueron los primeros que se plantearon esta hipótesis y propusieron la conducta de solo observar y no operar a aquellos micro CPT que a priori se presentaban como de bajo riesgo (85).

Sugitani y col (86) del Instituto Nacional del Cáncer de Japón se basaron en un estudio retrospectivo previo de 178 pacientes con micro CPT no incidental confirmado por PAAF operados entre 1976 y 1993, que se discriminaban en un grupo mayoritario de 148 pacientes con un tumor no incidental pero asintomático y un grupo de 30 pacientes con un tumor no incidental sintomático, ya 
fuera por la presencia de ganglios metastásicos y/o disfonía evidente. Ninguno de los 148 pacientes asintomáticos tuvieron recurrencias, metástasis o muertes, mientras que en el grupo de pacientes sintomáticos ocurrieron 4 casos de recurrencias y/o metástasis (13\%) y 4 fallecidos por el tumor $(13 \%)$.

Basados en estos resultados los autores plantearon la hipótesis de que los pacientes con micro CPT no incidentales pero asintomáticos podían ser solamente observados y no operados con un baja probabilidad de recurrencia. Entre 1995 y 2008244 pacientes aceptaron voluntariamente la política de solo seguimiento y no cirugía durante un período de seguimiento promedio de 5 años (rango 1- 17 años). Todos los diagnósticos fueron confirmados mediante PAAF. Se comprobó que $90 \%$ de los tumores permanecieron incambiados, 3\% disminuyeron de tamaño y solo en un $7 \%$ (22 casos) se comprobó aumento de volumen del tumor; de estos útimos 4 pacientes desarrollaron ademas metástasis ganglionares. Los 4 pacientes con desarrollo de metástasis ganglionares y 9 de los que aumentaron el volumen tumoral fueron operados y no se registraron recurrencias luego de 1-12 años de seguimiento. Ningún paciente desarrolló invasión extratiroidea o metástasis hematógenas.

Estos resultados se confrontaron con 56 pacientes operados entre 1976 y 2006 con tumores micropapilares no incidentales sintomáticos (disfonía y/o metástasis ganglionares), los cuales tuvieron un $38 \%$ de recurrencias y una tasa de mortalidad de $20 \%$ a 10 años y $53 \%$ a 20 años. En este grupo la extensión extratiroidea o extraganglionar, las metástasis ganglionares mayores a $2 \mathrm{cms}$ y el componente pobremente diferenciado fueron los factores que mas incidieron en el mal pronóstico.

Los autores concluyeron que la observación sin cirugía sería una alternativa válida y atractiva a la operación sistemática para el micro CPT no incidental asintomático, reduciendo costos asistenciales y evitando la iatrogenia de un sobretratamiento.

Como recomendación final proponen que los micro CPT no incidentales se clasifiquen en tres grandes grupos (86):

- Tipo I: Tumor asintomático detectado por imágenes y confirmado por PAAF. Solo observación sin cirugía, tiene un excelente pronóstico. Representa un 95\% de los casos.

- Tipo II: Es un estadio precoz del CPT usual de bajo riesgo. Se trata con cirugía conservadora si se detecta crecimiento tumoral y/o aparecen ganglios metastásicos durante el seguimiento. Tiene un buen pronóstico tratado solo con cirugía conservadora. Representa alrededor de un $5 \%$ de los casos.

- Tipo III: es un tumor sintomático de alto riesgo. Se trata con cirugía agresiva, radioablación y hormonosupresión. Representa un pequeño número de casos.

Si bien recientemente otros grupos estan tratando de imitar la experiencia de los japoneses (85), parece difícil que en nuestro medio y en muchos otros de similares características, donde prima la cancerofobia y el exceso terapéutico, los pacientes e incluso los propios médicos acepten este tipo de conducta. Aún esta por dilucidarse cual será el mejor enfoque terapéutico a futuro de esta entidad cuyo diagnóstico aumenta día a día. 


\section{Capítulo IV}

\section{Cáncer de Tiroides y Bocio Multinodular}

\section{IVa) Delimitación del tema}

El bocio multinodular (BMN) es por lejos la enfermedad mas frecuente de la glándula tiroides tanto en las regiones con carencia endémica de yodo como en las que tienen ingesta normal. La prevalencia en las regiones con deficiencia endémica de yodo puede superar el $6 \%$ de la población, en tanto que en las regiones no endémicas es de alrededor de 1\%. En los centros de referencia para el tratamiento de enfermedades tiroideas la tiroidectomía por BMN representa prácticamente el $50 \%$ de las operaciones tiroideas $(8,87,88)$. En una revisión realizada por Gómez Palacios y col $(88)$ de 407 tiroidectomías encontraron que $47 \%$ del total de operaciones fueron practicadas por BMN, $38 \%$ por nódulos tiroideos benignos y solo un $23 \%$ por cáncer de tiroides.

Si consideramos como ya se analizó que la incidencia de cáncer de tiroides (CT) en la población general es actualmente de alrededor de 10 casos por cada 100.000 habitantes $(0,01 \%)$ y que la de $\mathrm{BMN}$ en regiones no endémicas es de $1 \%$ y en regiones endémicas de $6 \%$, resulta que el BMN es respectivamente 100 y 600 veces mas frecuente que el cáncer de tiroides.

El BMN es una afección tiroidea benigna, el ciclo etiopatogénico que lo caracteriza, conocido como la historia natural de la enfermedad, no guarda ninguna relación conocida con la carcinogénesis, por lo cual la concomitancia en una misma glándula de un carcinoma tiroideo debería considerarse como una simple asociación lesional casual $(8,32)$.

Sin embargo, la posible concomitancia o asociación lesional de cáncer tiroideo en una afección tan común como es el BMN ha sido y continúa siendo motivo de preocupación y análisis en la literatura. El riesgo de CT en el BMN ha dado lugar a interpretaciones y conductas tan diversas que van desde la recomendación de tiroidectomía total "profiláctica" para todo BMN (89) hasta la cirugía selectiva solo en aquellos casos de BMN voluminosos y/o con clara sospecha de malignidad (90). 


\section{IVb) Aspectos epidemiológicos}

Las tasas globales de hallazgo de CT en el BMN publicadas en la literatura oscilan entre un 1 $17 \%(8,90)$, pero estudios mas recientes las ubican en el entorno de $8-10 \%(88,91,92,93)$.

Los CT que se asocian a los BMN constituyen un grupo heterogéneo de tumores en cuanto a su forma de presentación, tamaño tumoral, posibilidades diagnósticas preoperatorias y agresividad biológica.

La primera gran división es aquella que diferencia entre los tumores diagnosticados en el pre y/o en el intraoperatorio o "no incidentales" y aquellos que se encuentran casualmente en el estudio anatomopatológico de la pieza de tiroidectomía denominados "ocultos" o "incidentales". Cualquiera de estas dos formas de presentación puede corresponder a tumores mayores a $10 \mathrm{mms}$ o bien menores o iguales a $10 \mathrm{mms}$ o microcarcinomas. Sin embargo, dadas las posibilidades diagnósticas de los métodos de imagen y la PAAF con mayor frecuencia los tumores no incidentales son mayores a $10 \mathrm{mms}$ y los incidentales microcarcinomas, pero ello esta cambiando en los últimos tiempos gracias al gran desarrollo y difusión de las imágenes de alta resolución. En términos generales se puede considerar que de no mediar factores de riesgo tales como la exposición a radiación u otros, el 75\% de todos los cánceres diagnosticados en los BMN son microcarcinomas, y de ellos la mayoría son incidentales. Estos tumores no suelen guardar relación con los típicos nódulos benignos del BMN, ni siquiera con los llamados "dominantes", sino que habitualmente se ubican en el "parénquima internodular" $(8,32,89,90,91,92,93)$.

Como en definitiva el porcentaje de hallazgo de CT en el BMN promedia el $10 \%$, y la probabilidad de malignidad en los nódulos tiroideos solitarios (NTS) o sus equivalentes es también de alrededor del $10 \%$, algunos autores afirman que el riesgo de CT es similar tanto para el NTS como para los nódulos múltiples del BMN $(89,94,95)$. Sin embargo, como ya se analizó en la sección de nódulo tiroideo y en la de microcarcinoma esta forma de razonamiento es engañosa, por cuanto los cánceres que asientan en los NTS son mayoritariamente tumores de 10 o mas mms y con potencial agresividad, en tanto que la mayor parte de los CT que asientan en los BMN son microcarcinomas incidentales pocas veces relacionados con los nódulos y de buen pronóstico. Ambos riesgos son porcentualmente similares pero totalmente dispares en cuanto a sus implicancias pronósticas, y no pueden ser comparados en modo alguno.

Del punto de vista anatomopatológico mas del $90 \%$ de todos los CT del BMN son CPT, especialmente micro CPT, con menos frecuencia se pueden encontrar CFT y mucho mas raramente otros tumores tiroideos $(8,32,88,89,91,92,93)$.

En relación al tamaño de los tumores incidentales encontrados en BMN eutiroideos predominan los microcarcinomas como ya se dijo, pero en porcentajes variables según las diferentes series: 


\section{CPT incidental en BMN eutiroideos}

\begin{tabular}{|c|c|c|c|c|}
\hline Fuente & BMN (n) & $\%$ CT incidental & $\begin{array}{c}\% \text { Microcarci- } \\
\text { noma }\end{array}$ & $\begin{array}{c}\% \text { Tu }>10 \\
\mathrm{mms}\end{array}$ \\
\hline Ríos (91) & 672 & 8,8 & 63 & 27 \\
\hline Gómez (88) & 190 & 8,5 & 75 & 25 \\
\hline Giles (89) & 218 & 8,2 & 72 & 28 \\
\hline Prades (93) & 270 & 12,2 & 50 & $50^{*}$ \\
\hline
\end{tabular}

(* $8 \%$ de los pacientes se operaron por sospecha de malignidad)

En el estudio de Giles y col (89) 39 de los 218 pacientes con BMN tenían "nódulo dominante", pero solo se encontró CT en 1 de ellos y no estaba topografiado en dicho nódulo.

\section{IVc) Posibilidades diagnósticas}

El diagnóstico tanto preoperatorio como intraoperatorio del CT en el BMN es usualmente difícil, debido a varios factores, baja prevalencia, abundancia de nódulos de morfología y funcionalidad diversa, baja probabilidad de malignidad en los nódulos, escasa o nula significación como marcador de malignidad del llamado "nódulo dominante", predominio de microcarcinomas y finalmente baja sensibilidad de los métodos diagnósticos mas utilizados: ecografía, centellografía, PAAF y biopsia intraoperatoria por congelación (8).

La ecografía, incluso con el auxilio del doppler color, tiene una baja sensibilidad para el diagnóstico de CT en el BMN. En el estudio de Ríos y col (91) fue de solo 14\%, por cuanto solo detectó 6 de los $44 \mathrm{CT}$ presentes en los $672 \mathrm{BMN}$ estudiados. Como contrapartida su especificidad puede ser buena cuando se detectan elementos de alta sospecha de malignidad tales como tamaño mayor a $3 \mathrm{cms}$, nódulo sólido o mixto, contornos irregulares, hipoecogenicidad, pérdida del halo ecogénico periférico, microcalcificaciones, y vascularización central tipo III. En el estudio mencionado la especificidad llegó a un inusual 96\%.

La centellografía en condiciones de eutiroidismo no aporta ningún elemento diagnóstico de interés para el CT en el BMN, salvo quizá en el tamizaje de los nódulos hipervascularizados,los cuales si son calientes raramente serán malignos (1)

La citología por PAAF, pilar fundamental en el diagnóstico de malignidad de los nódulos tiroideos en general presenta una utilidad muy limitada en la detección de CT en el BMN. Como la probabilidad de malignidad en los nódulos es baja la punción sistemática de los nódulos de mas de $10 \mathrm{mms}$ y la de los nódulos dominantes tiene rendimientos pobres. Por otra parte resulta impracticable por el gran número de nódulos. A esto se agrega que la mayor parte de los microcarcinomas son difíciles de localizar y de puncionar. En el estudio de Ríos (91) se utilizó en forma generosa la técnica de PAAF, puncionando todos los nódulos dominantes y aquellos que tenían alguna sospecha por ecografía; aún así la sensibilidad fue de solo $17 \%$, siendo ignorados mas del $80 \%$ de los CT de la serie. Como 
contrapartida la especificidad es alta cuando se aplica selectivamente sobre nódulos con varios elementos ecográficos de sospecha, en este estudio fue de $96 \%$.

El estudio anatomopatológico intraoperatorio por congelación tiene las mismas limitaciones que la PAAF cuando es realizado en forma no selectiva, con una sensibilidad de solo $19 \%$ en el estudio citado. Su especificidad fue de $100 \%$.

\section{Estrategia diagnóstica}

Desde el valioso estudio de Papini (33) que revolucionara la estrategia diagnóstica para los nódulos tiroideos en general, trabajo al cual ya nos hemos referido en el capítulo de nódulo tiroideo, tanbién se ha marcado en los últimos tiempos una tendencia similar que se vuelca hacia una utilización selectiva de la PAAF en el BMN $(1,6,8,94,95,96)$.

Estos aportes han contribuído significativamente a desmistificar el viejo, arraigado y cancerofóbico concepto del "nódulo dominante" como elemento de sospecha de malignidad. El nódulo dominante solo rara vez se correlaciona con el hallazgo de malignidad $(8,89)$.

El concepto actual se basa en que la PAAF se aplicará selectivamente y con guía ecográfica solo al "nódulo discordante", terminología que hemos tomado de Crestanello (2). La discordancia queda definida fundamentalmente por factores de sospecha detectables por ecografía, aunque ocasionalmente la clínica también puede aportarlos, tales como nódulo pétreo, disfonía y/o adenopatías. Los factores ecográficos discordantes, es decir aquellos que se correlacionan mas frecuentemente con malignidad son hipoecogenicidad, pérdida del halo ecogénico, contornos irregulares o infiltrativos, microcalcificaciones y vascularización central en el doppler $(1,8,20,21,32,33)$.

No esta justificado en ningún caso realizar punciones sistemáticas a ciegas de ambos lóbulos tiroideos tal como se preconizaba en el pasado en nuestro medio para los BMN.

La biopsia intraoperatoria por congelación puede tener su indicación cuando el paciente llega a la cirugía con un BMN y una elevada sospecha de $\mathrm{CT}$, ya sea con PAAF confirmatoria o no. En estos casos si bien el resultado anatomopatológico no influye en la extensión de la resección glandular, que a nuestro juicio debe ser siempre una tiroidectomía total, puede tener un papel gravitante en caso de presencia de adenopatías sospechosas, influyendo decisivamente en la indicación de un eventual vaciamiento ganglionar $(1,2,8,22,32)$.

\section{IVd) Implicancias pronósticas y terapéuticas}

Con respecto a los micro CPT incidentales que se detectan en los BMN su significado pronóstico no difiere en nada del que ya hemos referido en la sección de microcarcinoma y es similar para cualquier hallazgo de micro CPT incidental sea cual sea la patología tiroidea benigna de fondo que motivó la cirugía. La gran mayoría de estos micro CPT incidentales tienen un excelente pronóstico y curan luego de una tiroidectomía que los haya resecado completamente, incluso una subtotal, no requiriendo de ninguna otra intervención terapeútica. El hallazgo de factores de peor pronóstico tales como evasión extratiroidea, multifocalidad, metástasis ganglionares, metástasis hematógenas 
y/o componente indiferenciado en el tumor condicionan un tratamiento quirúrgico mas agresivo, radioablación y hormonosupresión $(10,80,81,82,83,84)$.

Los tumores no papilares, no incidentales y/o los mayores a $10 \mathrm{mms}$ en principio se tratan como tumores de potencial agresividad, mediante tiroidectomía total, radioblación y hormonosupresión $(10,32,74,80,81,82,83,84)$.

Queda planteada la posibilidad de realizar solo observación sin cirugía en aquellos micro CPT asintomáticos detectados en BMN, tal como proponen los autores japoneses (85), pero en el caso del BMN se suma la indicación quirúrgica de tiroidectomía total por razones de masa y crecimiento progresivo, con posibilidad de complicaciones por compresión, por lo cual la mayor parte de las veces se realiza la cirugía. La presencia de un micro CPT aún asintomático constituye indudablemente un aliciente para indicar la ciugía al menos en la mayoría de los países (8). 


\section{Bibliografía}

1) CIMARRA L y col. El Problema de los Nódulos Tiroideos. Nódulo tiroideo solitario. En:Diagnóstico y Tratamiento de las Enfermedades Quirúrgicas de la Glándula Tiroides. Cap 2. Oficina del Libro FEFMUR, Montevideo 2006.

2) CIMARRA L, CRESTANELLO F. Tumoraciones Tiroideas. En: El Diagnóstico Contemporáneo en Cirugía General. Principios y Práctica. Cap 11. Arena, Montevideo 2005.

3) PROCOPIOU M, MEIER C. Evaluation of Thyroid Nodules. En: OERTLI D, UDELSMAN R. Surgery of the Thyroid ans Parathyroid Glands. Cap 5. Sprinter 2012 (eBook).

4) PERROS P. Thyroid Nodules. En: MAZZAFERRI E, HARMER C, MALLICK U, et al. Practical Management of Thyroid Cancer. Cap 4. Springer 2006.

5) AMERICAN ASSOCIATION of CLINICAL ENDOCRINOLOGISTS and ASOCIACIÓN MEDICI ENDOCRINOLOGI MEDICAL GUIDELINES for CLINICAL PRACTICE for the DIAGNOSIS and MANAGEMENT of THYROID NODULES. End Pract $2006 ; 12: 63$.

6) ROSS D. Editorial: Nonpalpable Thyroid Nodules Managing an Epidemic. J Clin End Met 2002; 87:1938.

7) NILSSON IL, ARNBERG F, ZEDENIUS J, et al. Thyroid Incidentaloma Detected by Fluordeoxiglucose Positron Emission Tomography / Computed Tomography: Practical Management Algorithm. WJSurg 2011; 35: 2691.

8) CIMARRA L y col. Bocio Multinodular Eufuncionante y Bocios Torácicos. En: Diagnóstico y Tratamiento de las Enfermedades Quirúrgicas de la Glándula Tiroides. Cap 4. Oficina del Libro FEFMUR, Montevideo 2006.

9) SOSA JA, HANNA JW, ROBINSON KA, et al. Increases in Thyroid Nodule Fine-Needle Aspirations, operations, and Diagnosis of Thyroid Cancer in the United States. Surg 2013; 154: 1420.

10) LOMBARDI CP, BELLANTONE R, DE CREA C, et al. Papillary Thyroid Microcarcinoma: Extrathyroidal Extensión, Lymph Node Metastases, and Risk Factors for Recurrente in a High Prevelence of Goiter Area. W Jour Surg 2010; 34: 1214.

11) CLARK DP, FAQUIN WC. Introduction and Clinical Aspects. En: CLARK DP, FAQUIN WC. Thyroid Cytopathology. Cap 1. Springer 2005.

12) NYSTROM E, BERG G, JANSSON S, et al. Thyroid Lumps. En: NYSTROM E, BERG G, JANSSON S, et al. Thyroid Disease in Adults. Cap 29. Springer 2011.

13) RICHARDSON DL. Ultrasound of the Thyroid. En: MAZZAFERRI E, HARMER C, MALLICK U, et al. Practical Management of Thyroid Cancer. Cap 26. Springer 2006.

14) LANFRANCHI ME. Ecografía de Tiroides. 1a ed. Madrid: Marbán Libros; 2001. 
15) KHARCHENKO VP, KOTLYAROV PM, MOGUTOV MS, et al. Ultrasound Diagnostics of Thyroid Diseases. Springer 2010.

16) LEBROWSKA U, DZIECIOL J, JURGILEWICZ D, et al. Power Doppler as a Method that is Better than Color Doppler for Evaluation of Thyroid Nodular Lesions. Wiad Lek 2001; 54:31.

17) WONG KT, AHUJA AT. Benign Thyroid Conditions. En: SOFFERMAN RA, AHUJA AT. Ultrasound of the Thyroid and Parathyroid Glands. Cap 5. Springer 2012.

18) WONG KT, LEE Y, AHUJA AT. Malignant Thyroid Conditions. En: SOFFERMAN RA, AHUJA AT. Ultrasound of the Thyroid and Parathyroid Glands. Cap 6. Springer 2012.

19) ALEXANDER E, HURWITZ S, HEERING J, et al. Natural History of Benign Solid and Cystic Thyroid Nodules. Ann Int Med 2003; 138:315.

20) CONSORTI F, ANELLO A, BENVENUTI C, et al. Clinical Value of Calcifications in Thyroid Carcinoma and Multinodular Goiter. Anticancer Res 2003; 23: 3089.

21) MESSINA G, VICECONTI N, TRINTI B. Echotomography and Color-Doppler in the Diagnosis of Thyroid Carcinoma. Ann Ital Med Int 1996; 11: 263.

22) CIMARRA L y col. El Diagnóstico Clínico y Paraclínico de las Enfermedades Tiroideas En:Diagnóstico y Tratamiento de las Enfermedades Quirúrgicas de la Glándula Tiroides. Cap 1. Oficina del Libro FEFMUR, Montevideo 2006.

23) NYSTROM E, BERG G, JANSSON S, et al. Other Investigations. En: NYSTROM E, BERG G, JANSSON S, et al. Thyroid Disease in Adults. Cap 4. Springer 2011.

24) CLARK DP, FAQUIN WC. How to Perform and Process a Thyroid FNA. En: CLARK DP, FAQUIN WC. Thyroid Cytopathology. Cap 2. Springer 2005.

25) CLARK DP, FAQUIN WC. Approach to Thyroid FNA Cytopathology: An Overwiew. En: CLARK DP, FAQUIN WC. Thyroid Cytopathology. Cap 3. Springer 2005.

26) ALI SZ, CIBAS ES. El Sistema Bethesda para Informar la Citopatología de Tiroides. Definiciones, Criterios y Notas Aclaratorias. Ed Journal SA, 2011.

27) SILVER SA, BUSSENIERS AE. Fine Needle Aspiration Citology of the Thyroid. En: OERTLI D, UDELSMAN R. Surgery of the Thyroid ans Parathyroid Glands. Cap 6. Sprinter 2012 (eBook).

28) WIESNER W, ENGEL H, STEINBRICH W, et al. Diagnostic Imaging of the Thyroid and Radioiodine Therapy.. En: OERTLI D, UDELSMAN R. Surgery of the Thyroid ans Parathyroid Glands. Cap 4. Sprinter 2012 (eBook).

29) DOMINGUEZ ESCRIBANO JR, POMARES FJ, LOPEZ PENABAD L. Papel de la Tomografía por Emisión de Positrones en el Cáncer Diferenciado de Tiroides. End Nut 2005; 52:243.

30) MUÑOZ PEREZ N, VILLAR del MORAL JM, MUROS FUENTES MA, y col. Could 18 F-FDG-PET/CT avoid Unnecessary Thyroidectomies in Patients with Cytological Diagnosis of Follicular Neoplasm? Lang Arch Surg 2013; 398:709.

31) DELGADO B, YAMETTI L, IRAOLA M. Nódulo Tiroideo: su Planteo Quirúrgico. Actualizaciones en Cirugía. 1aㅡ ed. Montevideo, Lib Med Edit ; 1986. 
32) CIMARRA L y col. Cáncer de Tiroides en General. Carcinomas Diferenciados: Carcinoma Papilar y Carcinoma Folicular. En:Diagnóstico y Tratamiento de las Enfermedades Quirúrgicas de la Glándula Tiroides. Cap 5. Oficina del Libro FEFMUR, Montevideo 2006.

33) PAPINI E, GUGLIELMI R, BIANCHINI A, et al. Risk of Malignancy in Nonpalpable Thyroid Nodules: Predictive Value of Ultrasound and Color - Doppler Features. Clin End Met 2002; 87:1941.

34) LINWAH Y. Thyroid Nodule Evaluation: How Much is Too Much?. Surgery 2013; 154:1417.

35) RIOS A, RODRIGUEZ J, CANTERAS M, et al. Diagnóstico Perioperatorio de Malignidad Asociada al Bocio Multinodular. Cir Esp 2004; 76:369.

36) SITGES SERRA A, SANCHO J. Bocio Multinodular. En: SITGES SERRA A, SANCHO J. Guías Clínicas de la Asociación Española de Cirujanos - Cirugía Endócrina. 1ạ ed Madrid; Arán Edit SA, 1999.

37) American Thyroid Association Professional Guidelines. Revised American Thyroid Association Management Guidelines for Patients with Thyroid Nodules and Differentiated Thyroid Cancer. November 2009.

38) CROTHERS B, HENRY M, FIRAT P, et al. Muestra no Diagnóstica o Insatisfatoria. En: ALI SZ, CIBAS ES. El Sistema Bethesda para Informar la Citopatología de Tiroides. Definiciones, Criterios y Notas Aclaratorias. Cap 2. Ed Journal SA, 2011.

39) MASSOLL N, NIZAM M, MAZZAFERRI E. Cystic Thyroid Nodules: Diagnostic and Therapeutic Dilemmas. Endocrinologist 2002; 12:185.

40) PLA MARTI V, FERNANDEZ MARTÍNEZ C, PALLAS REGUEIRA A, y col. Actitud ante los Quistes Tiroideos Recidivantes con Citología Benigna. Cir Esp 2005; 77:267.

41) JUNG H, YOUNG J, SEONG Y, et al. How to Manage Thyroid Nodules With Two Consecutive Non-Diagnostic Results on Ultrasonography-Guided Fine-Needle Aspiration. W J Surg 2012; 36:592.

42) ELSHEIKH T, COCHAND B, DE AGUSTIN P, y col. Resultado benigno. En: ALI SZ, CIBAS ES. El Sistema Bethesda para Informar la Citopatología de Tiroides. Definiciones, Criterios y Notas Aclaratorias. Cap 3. Ed Journal SA, 2011.

43) CIMARRA L y col. Hipertiroidismo. En:Diagnóstico y Tratamiento de las Enfermedades Quirúrgicas de la Glándula Tiroides. Cap 8. Oficina del Libro FEFMUR, Montevideo 2006.

44) YU X, PATEL P, CHEN H, et al. False Negative Fine-Needle Aspiration of Thyroid Nodules Cannot be Attributed to Sampling Error Alone. Am J Surg 2012; 203:331.

45) KRANE J, NAYAR R, RENSHAW A. Atipía de Significado Incierto o Lesión Folicular de Significado Incierto. En: ALI SZ, CIBAS ES. El Sistema Bethesda para Informar la Citopatología de Tiroides. Definiciones, Criterios y Notas Aclaratorias. Cap 4. Ed Journal SA, 2011.

46) TEIXEIRA G, CHIKOTA H, TEIXEIRA T. Incidence of Malignancy in Thyroid Nodules Determined to be Follicular Lesions of Undetermined Significance on Fine Needle Aspiration. W J Surg 2012; 36:69.

47) CHEN J, PACE C, KHIYAMI A, et al. Should Atypia of Undetermined Significance be Subclassified to Better Estimate Risk of Thyroid Cancer? Am J Surg 2014; 207:331. 
48) HENRY M, DE MAY R, BEREZOWSKI K. Neoplasia Folicular y Presunta Neoplasia Folicular. En: ALI SZ, CIBAS ES. El Sistema Bethesda para Informar la Citopatología de Tiroides. Definiciones, Criterios y Notas Aclaratorias. Cap 5. Ed Journal SA, 2011.

49) FAQUIN W, MICHAEL C, RENSHAW A, et al. Neoplasia Folicular de Células de Hürthle y Presunta Neoplasia Folicular de Células de Hürthle. En: ALI SZ, CIBAS ES. El Sistema Bethesda para Informar la Citopatología de Tiroides. Definiciones, Criterios y Notas Aclaratorias. Cap 6. Ed Journal SA, 2011.

50) CIMARRA L y col. Otros Tumores Tiroideos Malignos. En: Diagnóstico y Tratamiento de las Enfermedades Quirúrgicas de la Glándula Tiroides. Cap 6. Oficina del Libro FEFMUR, Montevideo 2006.

51) HUDAK K, MAZEH H, SIPPEL R, et al. Hürthle Cell Metaplasia on Fine Needle Aspiration Biopsy is not by Itself an Indication for Thyroid Surgery. Am J Surg 2012; 203:287.

52) PARANGI S, SUH H. The Role of Genetic Markers in the Evaluation and Management of Thyroid Nodules. Surg Clin NA 2014; 94:515.

53) MATHUR A, OLSON M, ZEIGER M. Follicular Lesions of the Thyroid. Surg Clin NA 2014; 94: 499.

54) DOMINGUEZ J, POMARES F, LÓPEZ L. Papel de la Tomografía por Emisión de Positrones en el Cáncer Diferenciado de Tiroides. End Nut 2005; 52:243.

55) WANG H, FILIE A, CLARK D, et al. Diagnóstico Presuntivo de Cáncer. En: ALI SZ, CIBAS ES. El Sistema Bethesda para Informar la Citopatología de Tiroides. Definiciones, Criterios y Notas Aclaratorias. Cap 7. Ed Journal SA, 2011.

56) AUGER M, TELOW E, YANG G, et al.Carcinoma Papilar de Tiroides y sus Variantes. En: ALI SZ, CIBAS ES. El Sistema Bethesda para Informar la Citopatología de Tiroides. Definiciones, Criterios y Notas Aclaratorias. Cap 8. Ed Journal SA, 2011.

57) PITMAN M, OERTEL Y, GEISINGER K. Carcinoma Medular de Tiroides. En: ALI SZ, CIBAS ES. El Sistema Bethesda para Informar la Citopatología de Tiroides. Definiciones, Criterios y Notas Aclaratorias. Cap 9. Ed Journal SA, 2011.

58) BONGIOVANNI M, FAQUIN W. Carcinoma Tiroideo Poco Diferenciado. En: ALI SZ, CIBAS ES. El Sistema Bethesda para Informar la Citopatología de Tiroides. Definiciones, Criterios y Notas Aclaratorias. Cap 10. Ed Journal SA, 2011.

59) STAERKEL G, LJUNG BM, SHIDHAM V, et al. Carcinoma Indiferenciado (Anaplásico) y Carcinoma Escamoso de Tiroides. En: ALI SZ, CIBAS ES. El Sistema Bethesda para Informar la Citopatología de Tiroides. Definiciones, Criterios y Notas Aclaratorias. Cap 11. Ed Journal SA, 2011.

60) LAYFIELD L, WAISMAN J, ATKINS K. Tumores Metastásicos y Linfomas. En: ALI SZ, CIBAS ES. El Sistema Bethesda para Informar la Citopatología de Tiroides. Definiciones, Criterios y Notas Aclaratorias. Cap 12. Ed Journal SA, 2011.

61) LEE S, SKELTON T, ZHENG F, et al.The Biopsy-Proven Benign Thyroid Nodule: Is Long-Term Follow-Up Necessary? J Am Coll Surg 2013; 217:81.

62) VASALLO JA. Cáncer de Tiroides. Cáncer en Uruguay. Montevideo; Registro Nacional de Cáncer, 1991; 2:161. 
63) VASALLO JA, BARRIOS E, DE STEFANI E, y col. Atlas de incidencia de Cáncer en Uruguay. Comisión Honoraria de Lucha contra el Cáncer. Montevideo; 2001.

64) COMISIÓN HONORARIA DE LUCHA CONTRA EL CÁNCER. REGISTRO NACIONAL DE CÁNCER. Incidencia del Cáncer en Uruguay 2005 - 2009.

65) DAVIES L, GILBERT W. Increasing Incidence of Thyroid Cancer in the United Status, 1973-2002. JAMA 2006; 295: 2164.

66) AMERICAN CANCER SOCIETY. Cancer Facts and Figures. Atlanta, 2014 (Online).

67) NYSTROM E, BERG G, JANSSON S, et al. Thyroid Cancer. En: NYSTROM E, BERG G, JANSSON S, et al. Thyroid Disease in Adults. Cap 30. Springer 2011.

68) GONZÁLEZ AGUILAR O. Cáncer de Tiroides. Relato Oficial del Congreso Argentino de Cirugía. Rev Arg Cir 1997; 73.

69) LI VOLSI V. Part II: Thyroid Tumors. En: LI VOLSI V. Surgical Pathology of the Thyroid. 1a ed. Philadelphia. WB Saunders Company, 1990.

70) NIXON I, GANLY I, PATEL S. Observation of Clinically Negative Central Compartment Lymph Nodes in Papillary Thyroid Carcinoma. Surgery 2013; 154:1166.

71) ZANOCCO K, ELARAJ D, STURGEON C. Routine Prophylactic Central Neck Dissection for Low-Risk Papillary Thyroid Cancer: A Cost-Efectiveness Análisis. Surgery 2013; 154:1148.

72) SOSA JA. Is Routine Prophylactic Central Neck Dissection Indicated for Low-Risk Papillary Thyroid Cancer: Can We Determine Cost-Efectiveness if we are Unsure About its Effectiveness and Safety? Surgery 2013; 154:1146.

73) KESSLER A, RAPPAPORT Y, BLANK A, et al. Cystic Appearance of Cervical Lymph Nodes is Characteristic of Metastatic Papillary Thyroid Carcinoma. J Clin Ultrasound 2003; 31:21.

74) KUO E, ROMAN S, SOSA J. Patients with Follicular and Hürthle Cell Microcarcinomas Have Compromised Survival: A Population Level Study of 22.738 Patients. Surgery 2013; 154:1246.

75) DRUCKER W, ROBBINS R. Papillary Microcarcinoma of the Thyroid. En: MAZZAFERRI E, HARMER C, MALLICK U, et al. Practical Management of Thyroid Cancer. Cap 29. Springer 2006.

76) FINK A, TOMLINSON G, FREEMAN JL, et al. Occult Micropapillary Carcinoma Associated with Benign Follicular Thyroid Disease and Unrelated Thyroid Neoplasms. Mod Pathol 1996; 9:816.

77) PELIZZO MR, PIOTTO A, RUBELLO D, et al. High Prevalence of Occult Papillary Thyroid Carcinoma in a Surgical Series for Benign Thyroid Disease. Tumori 1990; 76:255.

78) MICCOLI P, MINUTO MN, GALLERI D, et al. Incidental Thyroid Carcinoma in a Large Series of Consecutive Patients Operated on for Benign Thyroid Disease. Anz J Surg 2006; 76:123.

79) BALOCH Z, LI VOLSI V. Microcarcinoma of the Thyroid. Adv Anat Pathol 2006; 13:69.

80) ROTI E, UBERTI E, BONDANELLI M, et al. Thyroid Papillary Microcarcinoma: a Descriptive and Metaanalysis Study. Eur J End 2008; 159:659. 
81) NOGUCHI S, YAMASHITA H, MURAKAMI N, et al. Small Carcinomas of the Thyroid. A Long-Term Follow-Up of 867 Patients. Arch Surg 1996; 131:187.

82) PELLEGRITI G, SCOLLO C, LUMERA G, ET AL. Clinical Behavior and Outcome of Papillary Thyroid Cancers Smaller than 1,5 cms in Diameter: Study of 299 Cases. J Clin End Met 2004; 89:3713.

83) ORTIZ S, RODRÍGUEZ JM, TORREGROSA N, y col. Relación entre la Forma de Presentación y el Pronóstico del Microcarcinoma Papilar Tiroideo. Med Clin (Barc) 2003; 120:773.

84) DUNKI-JACOBS E, GRANNAN K, Mc DONOUGH S, et al. Clinically Unsuspected Papillary Microcarcinomas of the Thyroid: a Common Finding with Favorable Biology? Am J Surg 2012; 203:140.

85) BRITO J, HAY I, MORRIS J. Low Risk Papillary Thyroid Cancer. BMJ 2014; 348:3045.

86) SUGITANI I, TODA K, YAMADA K, et al. Three Distinctly Different Kinds of Papillary Thyroid Microcarcinoma should be Recognized: Our Treatment Strategies and Outcomes. W J Surg 2010; 34:1222.

87) HURLEY DL, GHARIB N. Evaluation and Management of Multinodular Goiter. Otolaryngol Clin NA 1996; 29:527.

88) GOMEZ PALACIOS A, GUTIERREZ MY GOMEZ J. Evolución y Resultados en el Manejo Quirúrgico del Bocio Multinodular. Cir Esp 2006; 80:83.

89) GILES Y, BOZTEPE H, TERZIOGLU T, et al. The Advantage of Total Thyroidectomy to Avoid Reoperation for Incidental Thyroid Cancer in Multinodular Goiter. Arch Surg 2004; 139:179.

90) HENNEMAN G. Multinodular Goiter. En: Abbott Laboratories. Thyroid Disease Manager - The Thyroid and its Diseases, 2002. Http://www.thyroidmanager.org/thyroidbook.htm.

91) RÍOS A, RODRÍGUEZ JM, CANTERAS M, y col. Diagnóstico Perioperatorio de Malignidad Asociada al Bocio Multinodular. Cir Esp 2004; 76:369.

92) MICCOLI P, MINUTO MN, GALLERY D, et al. Incidental Thyroid Carcinoma in a Large Series of Consecutive Patients Operated on for Benign Thyroid Disease. Anz J Surg 2006; 76: 123.

93) PRADES JM, DUMOLLARD JM, TIMOSHENKO A, et al. Multinodular Goiter: Surgical Management and Histopathological Findings. Eur Arch Otorhinolaryngol 2002; 259:217.

94) HEGEDUS L, BONNEMA S, BENNEDBAEK F. Management of Simple Nodular Goiter: Current Status and Future Perspectives. End Rev 2003; 24:102.

95) GRAFT H. Doenca Nodular de Tireóide. Arq Bras End Met 2004; 48:93.

96) CASTRO MR, GHARIB H. Continuing Controversias in the Management of Thyroid Nodules. Ann Intern Med $2005 ; 142: 926$. 


\title{
Segunda Parte
}

\author{
TRATAMIENTO
}

Dr. Edgardo Berriel 


\section{1) Introducción}

El tratamiento del nódulo tiroideo, y del cáncer diferenciado de tiroides han tenido varias revisiones y modificaciones en los últimos veinte años (1-6). Esto ha estado relacionado con la mejora en los métodos diagnósticos habituales, en particular la ecografía tiroidea y la punción aspiración con aguja fina (7-14); el aporte de la biología molecular con el estudio de marcadores tumorales diagnósticos y pronósticos (15-19); mejoras en el conocimiento de la patología y biología tumoral (20-25); y el desarrollo tecnológico con la incorporación de abordajes miniinvasivo, laparoscópico y robótico (26-30).

El cambio terapéutico más importante ha sido un cambio en el enfoque. La propuesta de tratamiento debe estar individualizada, adaptando los lineamientos generales a la situación particular del paciente, teniendo como guía principal la agresividad biológica de la enfermedad, en particular el riesgo de recidiva locorregional y a distancia (1-6,31-37).

Persisten controversias en múltiples aspectos terapéuticos, destacándose a modo de ejemplo: rol y aplicabilidad de métodos ablativos no resectivos (38), pertinencia de los distintos abordajes quirúrgicos (39-43), beneficios de los vaciamientos ganglionares profilácticos $(44,45)$.

La finalidad de nuestro trabajo será la revisión de estos tópicos. Los recuadros son opinión de autor basada en la revisión bibliográfica y la experiencia asistencial. 


\section{2) Equipo Multidisciplinario}

La metodología diagnóstica y las opciones terapéuticas a plantear en un paciente con patología tiroidea deben ser discutidas y resueltas en común acuerdo por el conjunto de profesionales médicos encargados de la asistencia del paciente, antes de su implementación (1-6, 46,47).

Esto evitará discrepancias y opiniones encontradas a posteriori de la realización de procedimientos, lo que de ocurrir puede llevar a conflictos y resultados terapéuticos no óptimos (48).

Debería contarse con protocolos de actuación institucional, que tengan en consideración las disponibilidades y la experiencia del centro asistencial.

Es altamente recomendable para nuestro medio que los principales actores asistenciales (endocrinólogo, cirujano, citólogo, patólogo, especialista en medicina nuclear) tengan instancias formales (ateneos) de discusión de los casos clínicos, y compartan lineamientos generales comunes.

Las recomendaciones asistenciales deberán respetar los principios éticos de Autonomía, Beneficencia, No Maleficencia y Justicia. Los dilemas éticos deben resolverse en conjunto con el Comité de ética Institucional (49).

Hay que consensuar el plan terapéutico con los demás colegas encargados de la asistencia del paciente. 


\section{3) Consentimiento informado}

El consentimiento informado es parte del proceso asistencial. En nuestra legislación está definido y regulado por la Ley no 18335 - PACIENTES Y USUARIOS DE LOS SERVICIOS DE SALUD, y el Decreto $n=274-010$.

En la Ley no 18335 se establece en su artículo 11 “Todo procedimiento de atención médica será acordado entre el paciente o su representante -luego de recibir información adecuada, suficiente y continua- y el profesional de salud. El consentimiento informado del paciente a someterse a procedimientos diagnósticos o terapéuticos estará consignado en la historia clínica en forma expresa. Éste puede ser revocado en cualquier momento."

En el Decreto no 274-010, que regula la ley previamente citada, se establece:

Artículo $16 \%$. El otorgamiento del consentimiento informado es un derecho del paciente y su obtención un deber del profesional de la salud

Artículo 17․ Todo procedimiento de atención a la salud será acordado entre el paciente o u representante y el profesional de la salud, previa información adecuada, suficiente, continua y en lenguaje comprensible para dicho paciente, debiendo dejar constancia en la historia clínica del consentimiento informado del paciente a someterse a procedimientos diagnósticos o terapéuticos

Artículo 25․ En los casos de intervenciones quirúrgicas y de procedimientos diagnósticos o terapéuticos invasivos, el consentimiento informado deberá otorgarse por rescrito, firmado conjuntamente por el profesional de la salud y el paciente.

La información deberá incluir:

a) Identificación y descripción del procedimiento

b) Objetivo que se pretende alcanzar

c) Beneficios que se pretende alcanzar

d) Consecuencias probables de la realización y de la no realización del procedimiento

e) Riesgos frecuentes

f) Riesgos poco frecuentes cuando sean de especial gravedad y estén asociados al procedimiento de acuerdo con el estado de la ciencia

g) Riesgos personalizados con la situación clínica del paciente

h) Advertencias sobre interacciones y contraindicaciones con otros procedimientos, tratamientos y medicamentos respecto a la situación actual del paciente

i) Advertencia sobre restricciones a su estilo de vida e incomodidades que pudiera aparejar 
j) Procedimientos alternativos, incluso los no disponibles en la institución pública o privada donde se realiza la atención de salud, sus riesgos y beneficios

De lo anterior se conceptualiza con claridad que la información del proceso asistencial es un derecho del paciente y una obligación ética y legal del equipo tratante.

La comunicación básicamente ha de ser verbal, clara, completa y veraz. Se han de explicar los pros y contra de las decisiones ha tomar, haciendo hincapié en los riesgos y efectos adversos. En relación a esto último se debe ser detallista, dado que existen ejemplos en nuestro medio de condenas judiciales a médicos por información insuficiente.

Debe quedar registro escrito de este proceso de información. Existe cierta controversia médico-legal en cuanto a cuál es el registro adecuado. Los formularios de tipo genérico son habituales, pero en general desaconsejados. Se recomienda tener un formulario de la institución, específico para el acto asistencial a realizar $(50,51)$.

Independiente de la formalidad, para la cirugía tiroidea ha de especificarse los riesgos de lesión nerviosa, en especial recurrencial, de lesión glandular paratiroidea, de lesión del eje visceral, de lesión vascular, infecciosos, de déficit funcionales endócrinos, y de muerte. De ser posible el equipo asistencial debería de cuantificar estos riesgos (52).

Corresponde informar al paciente y familiares en detalle las opciones terapéuticas, efectos adversos y posibles complicaciones, y dejar en la historia clínica registro de este proceder, firmado por médico, paciente y testigo. 


\section{4) Opciones terapéuticas para el nódulo tiroideo}

Varias opciones terapéuticas son posibles en un paciente con un nódulo tiroideo (1-6). Los factores a considerar en la decisión terapéutica ya fueron planteados, y en orden jerárquico corresponden al resultado de la citología, la evaluación ecográfica, elementos clínicos de sospecha de neoplasia, funcionalidad del nódulo, tamaño del nódulo y síntomas compresivos, consideraciones estéticas, y finalmente cancerofobia.

Se ha de tener un preciso juicio clínico para evitar el sobretratamiento de esta patología, en especial dado el aumento en la incidencia diagnóstica. La gran mayoría de los nódulos tiroideos no tendrán expresión clínica, y serán de naturaleza benigna (53-55).

Analizaremos las distintas opciones terapéuticas.

\section{a) Control evolutivo}

Ya se ha expuesto que nódulos tiroideos deben ser estudiados, y cómo. Cuando se trata de nódulos sin elementos de sospecha de malignidad, pequeños y asintomáticos, el control evolutivo es la mejor opción. En estas situaciones es esperable que un tercio disminuyan su tamaño, pudiendo llegar a desaparecer; otro tercio no tengan cambios o experimente un aumento leve de su tamaño; y que en el tercio restante haya un crecimiento mayor al 50\%, que pueda requerir algún tipo de terapéutica (55-56). En algunas series el porcentaje de nódulos con crecimiento importante ha sido mayor (57). Nódulos con crecimiento mantenido tienen un riesgo de hasta $26 \%$ de ser malignos (58).

\section{b) Hormonoterapia supresiva}

El uso de hormonoterapia con T4 para suprimir la TSH, y por ende frenar el crecimiento nodular es controvertido. Aún los metaánalisis han mostrado resultados contradictorios, a pesar de que en algunos de ellos se analizaron los mismos estudios $(53,55,59)$. En términos generales, podría esperarse un resultado beneficioso en 15 a 20\% de los pacientes tratados, siendo más adecuado su empleo en mujeres jóvenes pre menopáusicas, y desaconsejado para pacientes añosos por sus efectos colaterales adversos cardiovasculares y óseos $(60,61)$. Al momento actual, la mayoría de las guías de manejo del nódulo tiroideo no recomiendan su uso (2,4-6). 


\section{c) Radio-iodo}

El tratamiento con iodo radiactivo es una opción terapéutica segura y eficaz para los nódulos tiroideos con función autónoma (53). Su indicación principal es en los casos clínicos de pacientes mayores, con nódulos pequeños, y en pacientes de alto riesgo quirúrgico o que rechazan la cirugía (38). Es esperable una normalización de la función tiroidea en el 75-90\% de los pacientes a los 3-12 meses post terapia, una reducción del volumen del nódulo en el 30-40\% luego de 1-2 años, y un riesgo de hipotiroidismo a largo plazo del10-20\% (62-64). También se ha empleado el radio-iodo en pacientes con enfermedad nodular no funcionante, con hasta un $45 \%$ de reducción de tamaño, pudiendo emplear dosis más bajas con el agregado de TSH recombinante (53). En enfermedad de gran volumen, el efecto es menor (65).

\section{d) Ablación no resectiva}

Se han desarrollado una serie de procedimientos de ablación mini invasiva no resectiva para los nódulos tiroideos, en general guiados por ecografía. La estandarización de su empleo aún no está establecida, y alguno de ellos está en etapa evaluatoria $(2,4-6,38,53,55,61)$. Comentaremos los de mayor impacto.

La inyección percutánea de etanol ha sido empleada en muchos centros. Su efecto terapéutico esta dado por destrucción tisular por coagulación proteica y trombosis vascular. Se ha empleado para lesiones benignas y malignas, tanto sólidas como quísticas, funcionantes o no. Habitualmente se propone para nódulos de pequeño a moderado tamaño, y se realiza en una o varias sesiones. Suele ser un método económico, y de baja morbilidad, dada principalmente por dolor local, pero se han referido ocacionales complicaciones mayores $(38,53,55,61)$. Hay publicadas experiencias con número importante de pacientes. Como ejemplo, en el trabajo de Lee y cols, de cinco años, sobre 654 casos de lesiones benignas, que correspondieron a 198 nódulos sólidos, 432 lesiones quísticas complejas y 24 nódulos hiperfuncionantes, la respuesta completa (disminución del volumen mayor al $90 \%$ ) fue del 17,2\% en nódulos sólidos y de 19\% en nódulos quísticos complejos. Respuesta parcial (disminución de volumen entre $50 \%$ y $89 \%$ ) se obtuvo en el $71,7 \%$ de los nódulos sólidos, y $60,4 \%$ de los quísticos complejos. De los nódulos hiperfuncionantes, en solo un caso hubo desaparición clínico centellografica de la lesión. Hubo un $9 \%$ de complicaciones, con tres casos $(0,7 \%)$ de parálisis transitoria de cuerda vocal. Los autores concluyen que podría ser una terapia efectiva y segura, pero no aplicable a lesiones hiperfuncionantes (66). Otros han reportado mejores resultados con los nódulos autónomos, y en términos generales es esperable un $80 \%$ de normalización del funcional tiroideo en los adenomas pretóxicos, y $60 \%$ en las lesiones tóxicas; la reducción de tamaño se obtiene en el $65 \%$ de los casos (66). Para las lesiones quísticas es esperable una marcada reducción de tamaño, mayor al 50\%, en más del $75 \%$ de los pacientes tratados (68-70). La mayoría de los consensos, y es también opinión de los autores, consideran indicada la inyección percutánea de etanol solo para pacientes con lesiones quísticas benignas, recidivantes luego de la simple punción-evacuación, que no quieren o no pueden operarse $(2,4-6)$. 
La ablación por radiofrecuencia es otro procedimiento mini invasivo percutáneo utilizado para el tratamiento de los nódulos tiroideos benignos, sólidos ó quísticos, funcionantes o no. Habitualmente requiere anestesia local, equipamiento tecnológico y capacitación específica. Produce destrucción tisular térmica por acumulación de energía electromagnética local. Es un procedimiento costoso. Centros de Italia y Corea son los que han reportado mayor experiencia $(38,61)$. Se han obtenido buenos resultados en relación a disminución de tamaño y mejoría de síntomas en comparación con control, en períodos de varios meses $(71,72)$. Suele tener baja morbilidad, siendo el efecto adverso más común el dolor local transitorio. En una revisión multicéntrica, sobre 1459 pacientes, la tasa general de complicaciones fue de $3,3 \%$, con un $1,4 \%$ de complicaciones mayores, entre las que destacan 15 disfonías y 1 lesión de plexo braquial (73). En las lesiones quísticas, comparado con la inyección percutánea de etanol, tiene los mismos resultados siendo más laboriosa y costosa, por lo cual no está indicado en estas situaciones $(38,74)$.

La ablación térmica con láser es otra modalidad terapéutica desarrollada para el tratamiento percutáneo de nódulos tiroideos benignos, sólidos ó quísticos, funcionantes ó no. También requiere anestesia local, equipamiento específico, y entrenamiento técnico. Es un procedimiento laborioso y oneroso $(38,53)$. En un reciente estudio prospectivo, en pacientes con nódulos sólidos benignos de hasta $3 \mathrm{~cm}$, se compararon 101 pacientes tratados con 99 pacientes control; en un seguimiento a 36 meses, se observo una disminución mayor al $50 \%$ del volumen del nódulo en el $67 \%$ de los casos, en tanto en el grupo control hubo un aumento en el $25 \%$ de los pacientes (75). En nódulos funcionantes no ha mostrado ser mejor opción que el radio-iodo (76).

Otras modalidades de tratamiento reportadas, con experiencias muy limitadas incluyen la ablación por microondas y el ultrasonido focalizado de alta intensidad (38).

Todos estos procedimientos mencionados tienen buenos resultados en relación al control de síntomas, del tamaño lesional, y mejoras estéticas, pero no se dispone aún de evidencia suficiente, en cuanto a beneficios, riesgos y costos, para establecer indicaciones formales en el manejo de los nódulos tiroideos (77). Las distintas guías y consensos mencionan a algunos de ellos como alternativas válidas para casos seleccionados (2,4-6).

Varios de estos tratamientos se han empleado también en pacientes con cáncer tiroideo, en especial no operables para el control de recidiva local, metástasis cervicales ganglionares, metástasis distantes, y ocasionalmente para el control del tumor primario $(78,79)$.

\section{e) Cirugía}

La cirugía es una opción clásica de tratamiento para el nódulo tiroideo, y la táctica podrá variar según las circunstancias clínicas (1-6,53).

Para los nódulos citológicamente benignos, se plantea cirugía por tamaño, en general cuando son mayores a $3 \mathrm{~cm}$, por efectos compresivos locales, o por función autónoma cuando no está indicada o aceptada la ablación con radio-iodo. La táctica primaria consistirá en lobectomía más istmectomía, y resolución con el estudio patológico definitivo. Esto implica preobable reintervención, de lo 
cual el paciente debe estar correctamente informado. Podrá plantearse una tiroidectomía total de inicio en caso de antecedentes familiares de cáncer tiroideo, antecedentes personales de irradiación en cabeza y cuello, bocio multinodular con afectación bilateral, ó negativa del paciente a una eventual reintervención (1-6,53).

Los nódulos con citología folicular Bethesda III y IV, mayoritariamente serán benignos, y la táctica quirúrgica a plantear será lobectomía e istmectomía, y estudio anatomopatológico diferido a fijación en parafina (1-6,53). El mismo criterio se seguiría en las lesiones de Hürthle $(80,81)$. Podría plantearse tiroidectomía total de inicio si se dan las condicionantes planteadas en el párrafo anterior, ó si el nódulo es grande, mayor a $4 \mathrm{~cm}$, ó tiene elementos ecográficos de alta sospecha de malignidad (1-6,82,83). La consulta intraoperatoria con patólogo para estudio extemporáneo tiene bajo rendimiento diagnóstico para definir la naturaleza del nódulo folicular en estas categorias; su mayor utilidad está dada en la evaluación ganglionar de posibles adenopatías, y en la identificación de las paratiroides $(84,85)$.

Para las lesiones Bethesda V, sospechosas de carcinoma, la conducta será la lobectomía con istmectomía, pero aquí sí con estudio extemporáneo, dado el mejor rendimiento diagnóstico, sobre todo para las lesiones de tipo papilar, que serán las más frecuentes $(1-6,86,87,88)$. El uso concomitante de citología por impronta podría mejorar el rendimiento diagnóstico (89). De confirmarse carcinoma, se realizará tiroidectomía total $(1-6,53)$, con o sin vaciamiento ganglionar, como se discute más adelante.

El tratamiento quirúrgico puede realizarse por distintos abordajes (26-30), siendo la conducta clásica la cervicotomía transversa abierta. Las distintas opciones de abordaje serán tratadas más adelante.

La mayoría de los nódulos tiroideos son benignos y no requieren tratamiento. La hormonoterapia no tiene utilidad. Los nódulos hiperfuncionantes pueden tratarse con radio-iodo. Los nódulos quísticos benignos se evacúan por punción, y si se reproducen se podrían tratar con inyección percutánea de etanol. En todas las otras situaciones, si un nódulo requiere tratamiento, este es quirúrgico. No hay experiencia ni disponibilidad de los otros métodos de ablación no quirúrgica. Si el nódulo no tiene diagnóstico de cáncer, la táctica quirúrgica general es lobectomía e istmectomía, decidiendo tratamiento subsecuente con el estudio patológico definitivo. No se plantea tiroidectomía subtotal; la morbilidad es similar a la total. Si es un nódulo benigno, será un exceso terapéutico con riesgos innecesarios; si el nódulo es maligno, el tratamiento es inadecuado, exponiendo al paciente a un mayor riesgo de recidiva. 


\section{5) Opciones terapéuticas para el cáncer diferenciado de tiroides}

El tratamiento inicial actual del cáncer diferenciado de tiroides, entendiendo por tal al carcinoma papilar y al carcinoma folicular (incluyendo las variantes de Hürthle), se fundamenta en: a) resección quirúrgica oncológica del tumor con parte ó totalidad del tiroides, y de las vías de diseminación linfática cervicales; b) ablación por radio-iodo de restos tiroideos y metástasis, e c) inhibición del estímulo de crecimiento tumoral mediante freno a la secreción de TSH por administración de hormona tiroidea $(1,3-5,31-37,90)$.

Estos lineamientos terapéuticos generales deben adaptarse a características patológicas de la enfermedad, del paciente y del entorno asistencial. Los datos de seguimiento a largo plazo de pacientes tratados en centros de referencia han permitido identificar qué factores tienen incidencia en el pronóstico, e inciden en la sobrevida global y la sobrevida libre de enfermedad. Los de mayor importancia son: a) edad del paciente al momento del diagnóstico, b) metástasis hematógenas sistémicas, c) metástasis linfoganglionares regionales, d) extensión extratiroidea del tumor, e) tamaño tumoral, f) tipo histopatológico tumoral $(23-25,91,92)$. Algunos centros también consideran el sexo, la aneuploidia del ADN, mutaciones genéticas como las del BRAF y la extensión y radicalidad de la resección tiroidea $(34,91,93)$. Tomando estos elementos en consideración, se han propuesto múltiples sistema de estadificación con fines pronóstico. La tabla 1 muestra algunos de los múltiples sitemas de estadificación, y los elementos en ellos consignados (91). La tabla 2 muestra clasificación de las características patológicas según sistema TNM, y la tabla 3 los estadios del sistema TNM. Inicialmente, solo se jerarquizaba el concepto de sobrevida global. En el grupo de pacientes menores de 45 años, se reconocían dos grandes subgrupos; uno con enfermedad confinada al cuello, con un muy buen pronóstico de sobrevida global, y otro con enfermedad metástasica extracervical, con pronóstico menos favorable. Dentro del primer subgrupo, la sobrevida global es similar, pero no así la recaída tumoral, y por ende la sobrevida libre de enfermedad. Un cambio de jerarquía en el manejo de los pacientes con cáncer de tiroides ha sido la mayor y mejor estratificación de grupos de riesgo de recidiva/recurrencia, tomando en consideración los factores clínicos y patológicos mencionados, lo que permite proponer un tratamiento personalizado, con mejores resultados, menor morbilidad, y menores costos sanitarios, evitando subtratar ó sobretratar a los pacientes (tablas 4 y 5) (31-37,92,94-96).

Otro aspecto que tiene relevancia al momento de proponer el plan terapéutico es el centro sanitario donde se asiste el paciente, dado que existen diferencias en cuanto a lineamientos generales, en particular entre oriente y occidente (97). En los centros orientales se suelen proponer tiroidecto- 
mías menores que la total, vaciamientos ganglionares más extensos, y uso limitado del radio-iodo, en tanto en occidente la práctica más extendida es tiroidectomía total, vaciamientos ganglionares limitado, en particular los profilácticos, y amplio uso del radio-iodo postoperatorio. Existe una tendencia, con la aplicación de la estratificación de riesgo de recidiva, a unificar criterios y conductas (98).

Teniendo en cuenta este marco de referencia, analizaremos aspectos tácticos y técnicos de la cirugía del cáncer de tiroides.

\section{a) Tratamiento no quirúrgico inicial}

En nuestro entorno sanitario, el diagnóstico de que un nódulo tiroideo es sospechoso de cáncer ó corresponde a un cáncer papilar de tiroides implica indicación formal de cirugía resectiva terapéutica $(1,3-5,31,32,90,92)$. Este casi paradigma de nuestro medio, y en general de todo occidente, ha sido cuestionado por centros asistenciales orientales, en particular de Japón. Se ha planteado que en cierto grupo de pacientes es posible diferir la cirugía, controlar la evolución clínico-ecográfica de los pacientes, y operar a estos si aparecen cambios patológicos, sin que implique detrimento pronóstico (99). Esta conducta ha sido planteada para el microcarcinoma papilar (tumor menor a $10 \mathrm{mmm}$ ), intra-tiroideo, unifocal, sin evidencia de compromiso metastásico ganglionar y con citopatología papilar clásica. Los pacientes con esta situación clínica es conocido que tienen un excelente pronóstico, con sobrevida superior a $98 \%$ a los 20 años. Como ejemplo, en la experiencia reportada por Ito y col; entre los años 1993 y 2011 se controlaron 1235 pacientes con esta situación clínica, con un período medio de observación de 60 meses. Por distintos motivos, se terminaron operando 191 pacientes(15,5\%), pero solo 43 pacientes(3,5\%) por progresión clínica de la enfermedad, entendiendo por tal aumento de tamaño tumoral a más de $12 \mathrm{mmm}$., y/o aparición de metástasis ganglionares. Ningún paciente desarrollo metástasis sistémicas ni murió por la enfermedad. Un dato particular fue que la progresión lesional fue más frecuente en pacientes menores de 40 años, que en mayores de 60 años (100).

Dado el aumento en la incidencia de los microcarcinomas papilares como hallazgos imagenológicos, estos son datos a tener muy presentes en el diseño de futuros lineamientos asistenciales. Por nuestra idiosincrasia asistencial, no parece ser una opción actual a plantear en nuestros pacientes.

Para las situaciones clínicas distintas del microcarcinoma papilar, el retardo en la instrumentación del tratamiento, es un factor desfavorable en la sobrevida global. La mortalidad a 20 años fue del $4 \%$ en los pacientes que iniciaron el tratamiento en el año subsecuente al diagnóstico, y aumento a $10 \%$ cuando el retardo terapéutico superó dicho plazo, diferencia que fue estadísticamente significativa. Los pacientes fallecidos tuvieron un retardo promedio de 18 meses en el inicio del tratamiento (cirugía), en tanto en los pacientes vivos fue de 4 meses (91).

Frente al diagnóstico de sospechosa o positividad de cáncer tiroideo, la conducta para nuestro medio es operar al paciente. 


\section{b) Tratamiento ablativo no quirúrgico}

Ciertas modalidades de tratamiento ablativo no resectivas, como la ablación con laser, se han empleado para tratamiento de carcinomas papilares tiroideos, en circunstancias clínicas seleccionadas, por ejemplo pacientes añosos con tumores intratiroideos pequeños, que no puedan o no acepten ser operados (101). Pero en término generales los tratamientos ablativos no quirúrgicos no tienen indicación de emplearse como tratamiento inicial para el cáncer diferenciado de tiroides.

Más aceptado es considerar el empleo de estos tratamientos en pacientes con recidiva local post-tiroidectomía, o en recidivas ganglionares cervicales, también en pacientes en los cuales la opción quirúrgica no es adecuada (102-104).

Los tratamientos ablativos no quirúrgicos no se emplean de inicio para el carcinoma tiroideo, pero pueden considerarse para las recidivas ó las metástasis.

\section{c) Tratamiento quirúrgico}

Al analizar el tratamiento quirúrgico del cáncer diferenciado de tiroides, se deben considerar ciertos aspectos perioperatorios.

\section{i) Equipo quirúrgico}

En la mayoría de los sistemas sanitarios no existe la Cirugía Endócrina ó la Cirugía Tiroidea como especialidad quirúrgica definida. Tampoco está establecido a que rama quirúrgica madre corresponde el tratamiento de esta patología, ya que en algunos centros son cirujanos generales, y en otros son otorrinolaringólogos, por ejemplo. A pesar de esto, muchas Sociedades Quirúrgica tienen Capítulos de Cirugía Endócrina, como la española, ó Asociaciones en Cirugía de Cabeza y Cuello, como la argentina, o la Asociación Americana de Cirujanos Endocrinos de USA. En nuestro medio, la cirugía tiroidea es realizada por Cirujanos Generales, habitualmente con cierta inclinación preferencial por el tema. La cirugía tiroidea es un procedimiento quirúrgico entre mayor y mayor complejo, dependiendo de la extensión de la resección tisular. Existe un demostrado "efecto centro", de tal forma que el índice de complicaciones está en relación con la experiencia del equipo quirúrgico y el volumen de pacientes asistidos. No hay un número preciso de procedimientos quirúrgicos tiroideos anuales para mantener un adecuado nivel de desempeño, pero aquellos cirujanos que realizan menos de diez cirugías tiroideas anuales, tienen mayor índice de desaciertos y complicaciones. Cirugía tiroidea compleja debe ser realizada por equipos quirúrgicos referentes (105). 
Si no se está actualizado y se realiza menos de 10 cirugías tiroideas anuales, lo correcto es derivar al paciente con cáncer de tiroides a un colega referente.

\section{ii) Preparación preoperatoria}

Además de los estudios diagnósticos pertinentes, el paciente debe contar con evaluación de la función tiroidea, ionograma con calcemia, evaluación de la motilidad de cuerdas vocales, evaluación radiográfica de columna cervical y vía aérea, y la evaluación bioquímica, cardiovascular y respiratoria que corresponda. Debe corregirse todo distiroidismo evidenciado, llevando al paciente a la cirugía en eutiroidismo (106). El desarrollo de check list para cirugía tiroidea ha permitido protocolizar está preparación (107).

Hay que asegurarse que el paciente tiene todos los exámenes y consultas preoperatorias necesarios

\section{iii) Internación}

Existen centros que realizan cirugía tiroidea como parte de programas de cirugía mayor ambulatoria, con alta en las $12 \mathrm{hrs}$. del postoperatorio, en general con aporte sistemático de calcio vía oral, e información al paciente de síntomas/signos de reconsulta inmediata $(108,109)$. Este accionar no es ampliamente compartido, dado que se podría retardar la identificación-corrección de complicaciones con riesgo de vida, como hematoma asfíctico de cuello o hipocalcemia severa (110). En nuestro medio, la cirugía tiroidea se realiza con ingreso programado al centro asistencial, en el preoperatorio cercano, y corta estancia, con alta entre las $24-72 \mathrm{hrs}$ del postoperatorio (106).

La cirugía tiroidea se realiza con internación de corta estancia

\section{iv) Anestesia}

La anestesia loco-regional para la cirugía tiroidea se ha utilizado históricamente en nuestro país, con buenos resultados (106). Hay centros con programas de cirugía tiroidea ambulatoria que hoy en día la emplean (109). En el presente, en nuestro contexto asistencial, la cirugía tiroidea oncológica se realiza con anestesia general. Es de rigor la consulta preoperatoria con el especialista anestesiólogo, y debe preverse el correcto y seguro manejo de la vía aérea $(106,111)$.

La cirugía tiroidea se realiza con anestesia general 


\section{v) Abordaje}

El abordaje quirúrgico universalmente aceptado y empleado es la cervicotomía anterior transversa arciforme media baja tipo Kocher, con labrado de colgajos músculo-cutáneo superior e inferior, e ingreso a la logia tiroidea por apertura vertical mediana de la aponeurosis cervical. Su cierre es anatómico, y no genera dificultades técnicas. Permite una correcta y cómoda exposición quirúrgica, tiene una curva de aprendizaje corta, no requiere instrumental especial, no genera costos adicionales al acto operatorio, y se puede realizar en cualquier centro quirúrgico de nuestro país $(92,106)$. Este es un abordaje clásico, que tiene mínima morbilidad en cuanto a dolor e infección. Produce una cicatriz que sigue las líneas de fuerza cutánea, produciendo mínima alteración estética, ampliamente aceptada por los pacientes en nuestro medio asistencial. Igual, el paciente debe ser correctamente informado sobre la posibilidad, de baja frecuencia, de desarrollar una cicatriz hipertrófica ó retracción/adherencia cutánea cicatrizal con repercusión estética (112).

El desarrollo tecnológico quirúrgico miniinvasivo, y la focalización en los factores estéticos cicatrizales por idiosincrasia cultural, han influido en el desarrollo en las últimas décadas de abordajes quirúrgicos alternativos, destacándose los abordajes video asistidos de distinto emplazamiento (cervicales, retroauriculares, axilares, torácicos, combinados), y los procedimientos robotizados. Se han empleado como opciones de abordaje tanto para el nódulo tiroideo como para el cáncer diferenciado de tiroides $(26-30,113,114)$. Con el fin de disminuir el dolor postoperatorio y mejorar el resultados estético de la cicatriz, se han reportado procedimientos mininvasivos cervicales, que emplean incisiones más pequeñas que la habitual, disección limitada, asociada ó no a magnificación endoscópica (minimally invasive video-assisted thyroidectomy, MIVAT, y minimally invasive nonendoscopic thyroidectomy, MINET) $(115,116)$. Implican contar con equipamiento y entrenamiento específico. Se insiste en la cuidadosa selección de los pacientes, teniendo como indicación lesiones menores a 35 $\mathrm{mmm}$, bocio pequeño sin prolongación intratorácica, sin tiroiditis, y sin evidencia de metástasis linfáticas en caso de carcinoma. En la experiencia controlada comparativa con la cervicotomía clásica, mostró resultados similares en eficacia y seguridad, con menor dolor postoperatorio inmediato y mejor resultado estético subjetivo, pero con mayor tiempo operatorio (117-120). Su uso en cirugía oncológica para carcinoma papilar mostró mayor porcentaje de pacientes con niveles elevados de tiroglobulina postoperatoria, aunque sin aumento de recidiva clínica (121).

Los procedimientos endoscópicos y robóticos pueden ser de abordaje cervical $(27,122)$ o de abordaje distante (retroauricular, axilar, torácico) $(26,29,30,113,114)$. Estos últimos han tenido en la pasada década un gran impulso, particularmente en oriente (Japón-Corea). La principal finalidad es minimizar o eliminar la cicatriz en el sector anterior del cuello.

El abordaje cervical endoscópico fue de los primeros en utilizarse. Las dificultades y complicaciones de la insuflación (hipercapnia y enfisema extenso), sumado al reducido espacio para la inserción de los trócares, con las dificultades técnicas que impone sobre su manejo, y la multiplicidad de los mismos, que generan varias pequeñas incisiones, no eliminando las cicatrices cervicales, agregando el mayor tiempo operatorio que implica, pueden explicar que la técnica no haya ganado muchos adeptos $(27,122)$. 
Los procedimientos endoscópicos distantes (torácicos, axilares), con abordajes uni o bilaterales han sido empleados por un importante número de centros $(26,113,114,123)$. La mayoría se realiza actualmente sin insuflación cerrada de gas. Se los ha empleado para el nódulo tiroideo y para cáncer diferenciado de tiroides, tanto en la tiroidectomía como en linfadenectomía $(124,125)$. Se destaca mucho la selección de los pacientes, no estando indicado para lesiones mayores a $3 \mathrm{~cm}$., ó con topografía muy posterior $(113,114)$. Se los considera por sus impulsores con eficacia y seguridad similar al abordaje cervical abierto, destacándose como gran ventaja, no dejar cicatriz cervical, que se refleja en una gran satisfacción cosmética por parte de los pacientes (126). Implican mayor tiempo operatorio, mayor dolor postoperatorio por mayores campos de disección, mayor índice de seromas, mayor tiempo operatorio, mayor estancia hospitalaria, más prolongada curva de aprendizaje, mayores costos quirúrgicos. Se ha reportado mayor índice de parálisis recurrencial transitoria, y complicaciones habitualmente no asociadas a la tiroidectomía como neumotórax o lesión de plexo braquial $(113,127)$.

La cirugía robótica ha tenido un gran desarrollo, incluyendo su utilización en cirugía tiroidea, tanto para lesiones nodulares como para carcinoma. Se la ha utilizado por distintos abordajes, siendo el axilar el más empleado $(29,30,113,114,128,129)$. En estudios referidos por su promotores, se la considera segura y eficaz, destacándose entre sus ventajas que no deja cicatriz cervical, obteniendo un alto grado de satisfacción cosmética $(120,128,129)$. Se ensalza que da visualización tridimensional del campo operatorio, que permite mayor seguridad y precisión en la disección gracias a su brazos articulados, y que es más ergonómica para el cirujano $(120,128)$. Sus desventajas son la mayor disección tisular, una mayor curva de aprendizaje que el abordaje convencional, aunque quizás menor que el endoscópico, y la posibilidad de complicaciones hasta ahora raras como lesión de plexo braquial, lesión de tráquea o esófago $(120,127)$. Implica disponer de equipamiento muy costoso, no accesible para la mayoría de los centros asistenciales, y los tiempos operatorios son marcadamente mayores. A pesar de no existir datos inequívocos de su fiabilidad, seguridad y de resultados iguales ó mejores que la técnica convencional, miles de pacientes han sido abordados por esta técnica, en especial en oriente. En un meta-análisis de once estudios en que se comparó tiroidectomía abierta con tiroidectomía robótica por abordaje axilar, con un total de 2375 pacientes, de los cuales 1536 fueron procedimientos robóticos, se concluyó que esta última era más prolongada, tenía mayor tiempo de internación y mayor riesgo de disfunción temporal recurrencial (130). En otro mata-análisis de 9 estudios con 2881 pacientes, 1122 operados por vía robótica, se concluyo que era tan eficaz y segura como la convencional o la endoscópica (131). En un reporte de experiencia multiinstitucional sobre 2014 pacientes con cáncer tiroidectomizados por abordaje robótico, la tasa de complicaciones mayores fue del 1\% (lesión recurrencial o del plexo braquial), y del 19\% para las menores (hipocalcemia transitoria, seroma). Los resultados oncológicos fueron considerados buenos (132). Vinculado a esto último, se ha planteado que podría ser mejor en relación al número de ganglios resecado en los vaciamientos ganglionares, en comparación con la convencional y la endoscópica (128). La cirugía tiroidea robótica tiene sus más importantes centros de desarrollo en Corea del Sur, Europa, Israel y algunos centros de Estados Unidos; es de destacar que en este último no está aprobada por las autoridades sanitarias, la cirugía robótica para la tiroidectomía. La mayoría de los autores señalan la necesidad de contar con más datos, antes de aceptar la tiroidectomía robótica como un proceder estándar. 
La cervicotomía transversa abierta es el abordaje formalmente indicado para la cirugía tiroidea, y el adecuado actualmente para nuestro sistema sanitario, pero el desarrollo tecnológico quizás permita en un futuro contar con alternativas válidas que mejoren los resultados quirúrgicos.

\section{vi) Conducta con los nervios laríngeos}

La lesión nerviosa, en particular la de los nervios laríngeos, es una de las complicaciones propias de la cirugía tiroidea $(23,24,106,112,127,133,134)$. Está en relación con la experiencia y entrenamiento del equipo quirúrgico. La lesión del laríngeo recurrente conlleva mayor morbilidad que la del laríngeo superior. Esta última se traduce clínicamente por fonastenia, en tanto la recurrencial unilateral por disfonía, y la recurrencial bilateral por insuficiencia ventilo-respiratoria, en especial en agudo, que implica riesgo de vida y eventual traqueostomía. No toda lesión tiene traducción clínica (135).

La identificación intraoperatoria rutinaria de los nervios se asocia con menor índice de lesión permanente. El conocimiento perfeccionista de la anatomía cervical, incluyendo las variaciones normales, y la experiencia son las principales herramientas de ayuda para el cirujano. No hay método paraclínico ni táctica quirúrgica infalible de identificación y preservación de la indemnidad de los nervios. Las distintas técnicas de neuromonitorización y neuroestimulación intraoperatoria, que algunos centros preconizan, ayuda en la identificación de los nervios laríngeos recurrentes, pero no se ha demostrado que disminuya en forma significativa el índice de lesión recurrencial (136-138).

La magnificación visual, con el empleo de equipo endoscópico, lupas ó microscopio, también pude ayudar en la identificación nerviosa, aunque implica disponibilidad del recurso y entrenamiento particular del cirujano en su uso. Son de particular ayuda en la realización de procedimientos de reparación de lesiones evidenciadas $(138,139)$.

Todos los centros quirúrgicos que realizan cirugía tiroidea tienen lesiones recurrenciales. Los índices de disfonía transitoria son muy variables y rondan el 5-8\%. El índice de lesión recurrencial definitiva convencionalmente aceptado es de $2 \%(23,24,106,112,127,133,134,138)$.

La extensión de resección glandular es un factor que incide en la probabilidad de lesión recurrencial. Es mayor en la tiroidectomía subtotal y total, en comparación con la lobectomía, pudiendo llegar a ser grave en caso de lesión bilateral (133-135). Este hecho debe ser considerado por el equipo asistencial y el paciente al momento de decidir la modalidad de tratamiento quirúrgico.

Se debe informar al paciente correctamente sobre los riesgos de lesión recurrencial; estar entrenado e identificar los nervios en la cirugía son la mejor forma de evitar lesionarlos. 


\section{vii) Conducta con las glándulas paratiroides}

La lesión paratiroidea, con el hipoparatiroidismo e hipocalcemia subsecuentes, es también complicación conocida de la cirugía tiroidea $(23,24,106,112,127,133,134)$. Los mecanismos etiopatogénicos mas frecuentes son la isquemia por desvascularización y la resección inadvertida. Su incidencia tiene relación con la extensión de la resección tiroidea y con los vaciamientos linfoganglionares. La experiencia y entrenamiento del equipo quirúrgico también influyen. Se han propuesto métodos de tinción vital para su identificación, de limitada eficacia y reproductibilidad. La identificación con disección cuidadosa en el plano yuxta-capsular tiroideo, es la mejor modalidad quirúrgica para su preservación. Disponer de estudio patológico extemporáneo para confirmar la naturaleza paratiroidea de una estructura anatómica es de destacada utilidad. Si se confirma resección inadvertida ó desvascularización irreversible, está indicado el autoinjerto de fragmentos glandulares a nivel muscular, habitualmente esternocleidomastoideo.

Se ha propuesto que la dosificación de PTH rápida en el postoperatorio inmediato puede ser un predictor de función paratiroidea, en el sentido de que si los valores están en rango normal, la posibilidad de hipocalcemia sintomática es baja $(140,141)$. La hipocalcemia resultante de la disfunción paratiroidea es una situación de riesgo vital. Su corrección implica aporte de calcio y vitamina D. La disfunción paratiroidea transitoria es quizás la complicación postoperatoria más frecuente de la cirugía tiroidea, y puede evidenciarse hasta en el 50\% de los pacientes si se realizan calcemias rutinarias postoperatorias. El hipoparatiroidismo permanente es convencionalmente esperable en el $2 \%$ de los pacientes $(133,134)$. Este dato también debe ser considerado al momento de decidir la conducta quirúrgica.

Se debe informar correctamente al paciente sobre la posibilidad de disfunción paratiroidea; identificar y mantener un plano de disección cuidadosa yuxta-tiroideo es el mejor proceder para evitar la lesión paratiroidea.

\section{viii) Extensión de la resección tiroidea}

La tiroidectomía total constituye el tratamiento quirúrgico convencional para el cáncer diferenciado de tiroides $(1,3-5,23.24)$. En términos generales, la tiroidectomía total tiene mejores índices de sobrevida global y sobrevida libre de enfermedad que resecciones subtotales ó lobectomía $(92,93)$.

Sin embargo, existe controversia en cuanto a si esta conducta clásica es la más apropiada para todas la situaciones clínicas. Hay múltiples datos que permiten plantear resecciones glandulares menos extensas, como lobectomía más istmectomía (95-97). El cáncer diferenciado de tiroides es una enfermedad a priori con buen pronóstico. La sobrevida global a 10 años es mayor al $90 \%$. Con períodos largos de sobrevida global, cobra jerarquía el período de sobrevida libre de enfermedad, y la posible morbilidad de los tratamientos empleados. Hay que considerar elementos clínicos, patológicos, principios terapéuticos del equipo asistencial, morbilidad y costos de las opciones tera- 
péuticas, y elección del paciente, para definir la mejor extensión de resección glandular para una situación clínica particular (31-33).

Entre los elementos clínicos, la edad del paciente al momento del diagnóstico es una de las características de mayor determinismo en el pronóstico. Si bien variable, la mayoría de los centros de referencia en la patología toman una edad diferencial próxima a los 45 años. El porcentaje mayoritario de pacientes tendrá una edad menor a los 45 años, siendo esta la situación más favorable. El sexo del paciente tiene importancia, aunque mucho menor. Las mujeres tienen mejor prónostico que los hombres $(23,24,90,91,142)$.

Las formas histopatológicas más diferenciadas menos agresivas de cáncer diferenciado tiroideo son las más frecuentes, con un amplio predominio y aumento en incidencia del carcinoma papilar clásico. Hay un aumento en la incidencia diagnóstica de los estadíos tempranos de la enfermedad, debido al amplio uso de imagenología cervical. El tamaño del tumor primario tiene relación con el pronóstico, y con mayor frecuencia se diagnostican los tumores en tamaño más pequeño. El tipo papilar tiene una frecuente multicentricidad y bilateralidad, de discutida patogenia, pero que se reconoce como causa de recidiva lesional local cuando hay residuo glandular. También tiene frecuente y temprana diseminación metastásica ganglionar cervical; esto tiene poca importancia pronóstica en los pacientes jóvenes, no así en los mayores $(91,92,142)$.

La extensión extratiroidea del carcinoma, con invasión de tejidos y estructuras vecinas, es un reconocido factor pronóstico ominoso, que se relaciona con posibilidad de recidiva loco-regional. Se ha planteado que la recidiva loco-regional pudiera incidir negativamente en la sobrevida global $(91,92,143)$.

El cáncer diferenciado de tiroides es hormonodependiente de estímulo de TSH en su progresión. En general capta radio-iodo, aunque con una avidez marcadamente menor que el tejido tiroideo normal. La efectividad del empleo de radio-iodo como herramienta terapéutica para el cáncer tiroideo, en particular para el control metastásico, será máxima en ausencia de tejido tiroideo normal, y con estímulo de THS. El radio-iodo es ampliamente empleado en los centros asistenciales occidentales, y limitado en su uso, por disposiciones legales en los centros orientales, particularmente Japón (98).

La morbilidad de la terapéutica clásica para el cáncer diferenciado de tiroides, en general es baja en frecuencia, y bien tolerada, pero en ciertos casos puede ser de jerarquía, y ocasionalmente tan severa como la propia enfermedad neoplásica. Las complicaciones y secuelas de la cirugía están en relación con la experiencia del equipo quirúrgico y la extensión de la resección glandular $(133,134)$.

La tiroidectomía total encuentra sus principales argumentos en que elimina todo el tejido glandular disminuyendo los índices de recidiva loco-regional, mejorando esto la sobrevida libre de enfermedad, y en muchos pacientes la sobrevida global $(92,93)$. Permite el uso más efectivo del radioiodo, mejorando así también la sobrevida global y libre de enfermedad (92). Permite contar con la tiroglobulina y los anticuerpos anti-tiroglobulina como efectivos marcadores tumorales para el seguimiento, cuyos cambios evolutivos pueden usarse como factores pronósticos (142). Como desventaja tiene mayor índice de sangrado postoperatorio, mayor índice de lesión recurrencial, transitoria y permanente, mayor índice de lesión paratiroidea con hipoparatiroidismo/hipocalcemia, transitoria 
y definitiva $(133,134)$. Impone un hipotiroidismo definitivo, cuya importancia está relativizada por la necesaria hormonoterapia de supresión de TSH. Para el grupo de pacientes con muy buen pronóstico y muy bajo riesgo de recidiva, esta opción podría ser un exceso terapéutico, que los expusiera innecesariamente a las complicaciones mencionadas (95-97).

La lobectomía tiroidea con istmectomía es un tratamiento quirúrgico oncológico aceptado, pero menos empleado. No impone un hipotiroidismo definitivo, y tiene menos riesgo de complicaciones paratiroidea, recurrencial y de sangrado. Expone al paciente a un mayor riesgo de recidiva loco-regional, aunque de producirse puede en general tratarse con nueva resección quirúrgica. No permite el uso de radio-iodo, ni diagnóstico ni terapéutico. Tampoco permite el uso de tiroglobulina y anticuerpos anti-tiroglobulina como marcadores tumorales de seguimiento (91). En estudios de seguimiento general a largo plazo, ha mostrado menores índices de sobrevida libre de enfermedad y de sobrevida global $(92,93)$. Sin embargo, en grupos de buen pronóstico y bajo riesgo de recidiva, estos índices son similares comparados con la tiroidectomía total (144). La edad mayor podría no ser una limitante para esta opción quirúrgica, si se dan todas las otras condicionantes mencionadas, dado que en estudios de control evolutivo del microcarcinoma papilar, los pacientes jóvenes tuvieron mayor progresión tumoral que los pacientes mayores (100).

La tiroidectomía subtotal, empleada en nuestro medio como tratamiento quirúrgico oncológico en décadas pasadas, ha ido perdiendo aceptación. El volumen residual tiroideo es muy variable, no siempre posible de eliminar con radio-iodo. Tiene similar índice de recidiva loco-regional que la lobectomía con istmectomía, y similar índice de complicaciones que la tiroidectomía total. La reintervención de una logia tiroidea operada es técnicamente más dificultosa, y con mayor índice de complicaciones. Muchos centros asistenciales no al consideran una cirugía oncológica válida (95).

A modo de consideración general, se podría plantear que la tiroidectomía total será el tratamiento quirúrgico para la gran mayoría de los pacientes con un carcinoma diferenciado de tiroides $(90,92,95)$. Se podría plantear como opción quirúrgica inicial lobectomía con istmectomía para el paciente con un microcarcinoma papilar, de histología típica, unifocal, intratiroideo, sin compromiso metástasico evidente, sin antecedentes familiares de carcinoma tiroideo, sin antecedentes personales de radiación en cuello, que acepte seguimiento clínico-ecográfico estrecho, y acepte también un mayor riesgo de recidiva loco-regional, y de eventuales reintervenciones (145). Además, el paciente y el equipo asistencial, en particular endocrinólogo y especialista en medicina nuclear, deberán aceptar el no uso de radio-iodo, con la potencial pérdida del beneficio que aquel implica. Esto último no es habitualmente admisible en nuestro medio. Situación relacionada es la del paciente con microcarcinoma papilar en iguales características, que aparece como incidentaloma en pieza de lobectomía con istmectomía realizada por otro motivo. Aquí también habrá que evaluar la situación clínica para definir si se reopera ó no al paciente para completar tiroidectomía, sumando en la discusión el resultado operatorio en cuanto si hubieron o no complicaciones, en particular nerviosa recurrencial, y los datos del informe anatomo-patológico, destacando si hubo en la pieza resección inadvertida de paratiroides $(91,95)$. Algunos centros asistenciales utilizan además el hallazgo de ciertas mutaciones genéticas o alteraciones de marcadores moleculares en la toma de decisión terapéutica (145). Para el carcinoma folicular, el consenso más amplio es reoperar al paciente y realizar la lobectomía contralateral, considerando la tiroidectomía total como el tratamiento oncológico quirúrgico indicado, 
aún en casos de tumores pequeños y miniinvasivos (146). Otros opinan que en esta última situación, la lobectomía puede ser suficiente $(80-83,147)$

En nuestro medio, para el cáncer diferenciado de tiroides, la cirugía a proponer será tiroidectomía total; ocasionalmente se podrá aceptar la lobectomía con istmectomía para el microcarcinoma papilar. La tiroidectomía subtotal se desaconseja como operación oncológica.

\section{ix) Vaciamientos linfoganglionares}

El carcinoma papilar, el más frecuente de los carcinomas diferenciado de tiroides, tiene una frecuente y temprana diseminación metastásica ganglionar. La frecuencia está en relación con el tamaño del carcinoma primario y la existencia de multicentricidad. Estas metástasis ganglionares tienen poca importancia pronóstica en el paciente joven, y no se las considera fuente de metástasis sistémicas. Tienen mayor jerarquía en el paciente mayor (34). Muchas de las metástasis ganglionares nunca tendrán traducción clínica. Los carcinomas foliculares rara vez dan metástasis ganglionares. Una excepción la constituye el carcinoma folicular a células de Hürthle, que las puede presentar hasta en un $25 \%$ de los casos $(91,106)$.

El fenómeno metastásico ganglionar no tiene una diseminación anatómicamente reglada; es más frecuente, pero no exclusiva, la propagación homolateral. Se ha consensuado la división de los distintos grupos ganglionares cervicales, y se los divide en seis grupos, numerados en números romanos; algunos grupos están subdivididos en subgrupo, denominados con letras mayúsculas ( $A$, $B$, etc.). El grupo I incluye: A) ganglios submentonianos, y B) ganglios submaxilares. El grupo II comprende: A) ganglios yugulocarotídeos superiores, cefálicos a la proyección lateral del hioides, y B) retroauriculares y mastoideos. El grupo III corresponde a ganglios yugulocarotídeos medios, entre proyección lateral de hioides y cricoides. El grupo IV son los ganglios yugulocarotídeo inferiores, por debajo de la proyección lateral del cricoides, que del lado izquierdo involucra también el conglomerado de Troissier. El grupo V involucra: A) ganglios espinales, y B) ganglios supraclaviculares y cervicales transversos. El grupo VI corresponde a los ganglios centrales periviscerales, y se subdivide en: A) prelaríngeos (supraistmicos ó délficos), B) pretraqueales (infraistmicos), C) paratraqueales derechos (laterotraqueales o recurrenciales) y D) paratraqueales izquierdos (laterotraqueales o recurrenciales). Estos últimos se prolongan en continuidad hacia el mediastino supero-lateral izquierdo, ya que no existe estructura que determine un límite anatómico cervico-torácico. Algunos autores realizan la denominación de estos cuatro subgrupos en el sentido inverso a las agujas del reloj, de tal forma que B) corresponde a laterotraqueales derechos y C) corresponde a pretraqueales. Algunos autores también consideran un grupo VII, que corresponde a los ganglios mediastinales antero-superiores (de la logia tímica), dada su continuidad anatómica con los pretraqueales (148-150).

La confirmación pre ó intraoperatoria de metástasis ganglionares determina la realización de linfadenectomías consideradas terapéuticas. Al momento de la tiroidectomía está indicada la exploración visual y palpatoria de los grupos ganglionares accesibles. Toda adenopatía evidenciable se biopsia para estudio anatomopatológico extemporáneo. La sensibilidad de este estudio a nivel 
ganglionar es alta, aunque disminuye en la micrometástasis; la especificidad es alta (151). Se ha propuesto también utilizar la técnica del ganglio centinela para definir la conducta con el vaciamiento profiláctico. A diferencia del cáncer de mama, no es una táctica de amplio uso para el carcinoma papilar. Entre otras, las técnicas más utilizadas son el marcado por tinción con azul de metileno, y el radiomarcado con tecnecio radioactivo. La capacidad de detección del ganglio centinela ha sido reportada en promedio $83 \%$ para la primera, y $96 \%$ para la segunda (152). La sensibilidad ha sido buena y la especificidad ha sido alta para identificar compromiso metastásico ganglionar (153). Hay un aumento en los tiempos operatorios y los costos, en especial para el radiomarcado (152).

Ante la confirmación de metástasis ganglionares, la mayoría de los centros aconseja realizar procedimientos resectivos reglados conservadores, sin sacrificio de estructuras musculares, vasculares ó nerviosas que no estén directamente comprometidas. Si existen metástasis en ganglios peritiroideos, en el denominado grupo $\mathrm{VI}$, se realiza la linfadenectomía denominada vaciamiento central que incluye la totalidad de los ganglios del grupo $\mathrm{VI}$, y para algunos autores también corresponde resecar el llamado grupo VII $(154,155,156)$.

La presencia de metástasis ganglionares en ganglios fuera del compartimiento central (grupo VI), implica la realización de una linfadenectomía cervical homolateral subradical (vaciamiento subradical de cuello). Esto comprende habitualmente la resección de los grupos ganglionares IIA, III, IV, VB, vena yugular externa, ramos nerviosos del plexo cervical superficial y músculo omohioideo, con preservación de músculo estermocleidomastoideo, vena yugular interna y nervio espinal. Eventualmente podrán realizarse procedimientos quirúrgicos bilaterales, si el cuadro clínico lo amerita. Resecciones locales de ganglios comprometidos ("berry picking") no están recomendadas $(154,155)$.

Frente a la no evidencia manifiesta clínica-imagenológica ni operatoria de metástasis ganglionares surge la controversia de la pertinencia y beneficio de las linfadenectomías profilácticas $(44,45,157)$. Quienes promueven la realización de vaciamientos profilácticos centrales sistemáticos argumenta que en el carcinoma papilar es esperable la presencia de metástasis ganglionares en un promedio de $40 \%$ de los casos (hasta $90 \%$ en algunos reportes), que la exploración quirúrgica tiene baja sensibilidad para detectarla, y que una reintervención por recidiva en una logia tiroidea operada aumenta los índices de complicaciones quirúrgicas recurrenciales y paratiroideas. El vaciamiento ganglionar sistemático daría una más precisa estadificación del paciente, con implicancias terapéutico-pronósticas, Lograría niveles más bajos de tiroglobulina, factor importante para el seguimiento; disminuiría el índice de recidiva loco-regional, y podría mejorar la sobrevida global $(44,45,154,155,157)$.

Aquellos que plantean la no realización de vaciamientos centrales profilácticos aducen que la traducción clínica evolutiva de las metástasis ganglionares no evidentes es muy baja, de tal forma que solo un hasta $8 \%$ de los pacientes operados sin vaciamiento desarrollaran metástasis ganglionares centrales clínicas $(44,45,157)$. En un metaánalisis de estudios en que se evaluó la recidiva loco-regional en pacientes sometidos a tiroidectomía total sin vaciamiento central profiláctico (TT), y pacientes con tiroidectomía total con vaciamiento profiláctico ( $T T+V G)$, se evidenció una menor recidiva en este último caso ( $\mathrm{TT}-7,9 \%, \mathrm{TT}+\mathrm{VG}-3,8 \%$ ), aunque sin significación estadística, y con mayor morbilidad (158). También se aduce que los vaciamientos linfoganglionares aumentan la 
morbilidad paratiroidea y recurrencial de la cirugía tiroidea, y se aumenta el tiempo operatorio $(44,45,154,155,157-160)$.

Otros elementos a considerar en la discusión es que las metástasis ganglionares centrales esta en relación directa con la presencia de multicentricidad, el tamaño del tumor primario, y la extensión extratiroidea del mismo (161). El significado pronóstico de la metástasis ganglionar tiene poca jerarquía en el paciente joven, pero mayor en el paciente añoso, y en términos generales puede afectar la sobrevida. La metástasis ganglionar, en especial la micrometástasis puede ser controlada con el radio-iodo $(44,45,157)$.

La controversia con el vaciamiento central profiláctico no está resuelta $(44,45,154,155,157)$. Las opiniones actuales tienden a adecuar la conducta a la situación clínica del paciente, considerando el pronóstico y la estratificación del riesgo de recurrencia $(44,45,154,155,157)$. Los siguientes planteos serían ejemplos en tal sentido. En el paciente de buen pronóstico y bajo riesgo de recidiva, esto es paciente menor de 45 años, con tumor papilar típico intratiroideo único menor de $2 \mathrm{~cm}$ (T1), es planteable la no realización de vaciamiento central profiláctico, ó realizar una resección limitada a los grupos prelaríngeos y pretraqueales. Para las situaciones clínicas de mal pronóstico y riesgo elevado de recidiva loco-regional, esto es pacientes mayores con carcinomas de variante histopatológicas agresivas, con tumores grandes, mayores a $4 \mathrm{~cm}$ (T3), y/o compromiso tumoral extratiroideo (T4), la mayoría acepta un vaciamiento linfoganglionar profiláctico central completo del grupo $\mathrm{VI}, \mathrm{Y}$ eventualmente grupo VII. Para las otras situaciones intermedias, esto es paciente joven con riesgo moderado-alto de recidiva $(\mathrm{T} 3, \mathrm{~T} 4)$, paciente mayor con riesgo bajo de recidiva $(\mathrm{T} 1, \mathrm{~T} 2)$, podría plantearse linfadenectomías centrales profilácticas homolaterales, lo que implica la resección de los ganglios prelaríngeos, pretraqueales y laterotraqueales (recurrenciales) homolaterales, preservando los laterotraqueales contralaterales (162-164).

Se ha referido que los carcinomas papilares que presentan mutaciones genéticas a nivel de BRAF V600, tienen un curso clínico más agresivo y mayor compromiso ganglionar metastásico. Se ha propuesto el empleo de la determinación de mutaciones del BRAF V600 para determinar la realización de vaciamientos ganglionares profilácticos. Otros marcadores moleculares, entre ellos receptores celulares como GPER1, EGFR y CXCR1 también han sido referidos en igual sentido $(165,166)$.

No está indicado realizar vaciamientos centrales profilácticos en el carcinoma folicular, a excepción del carcinoma de Hürthle $(80,81)$, en cuyo caso podría actuarse con los lineamientos descritos para el carcinoma papilar.

No están indicados en nuestro medio, ni en occidente, la realización de vaciamientos ganglionares cervicales profilácticos laterales $(44,45,154,155,157)$; distinta es la conducta en oriente, en especial Japón, donde si están aceptados (167). 
La confirmación de metástasis ganglionares implica la linfadenectomía reglada del compartimiento comprometido. El vaciamiento central es controvertido; su realización estaría vinculada a la situación clínica del paciente, siendo en general aceptado en tumores mayores a $4 \mathrm{~cm}$ o con compromiso extratiroideo. Los vaciamientos laterales profilácticos no tienen indicación. 


\section{6) Bibliografía}

1) PITOIA F, CALIFANO I, VÁZQUEZ A, et al. Consenso intersocietario sobre tratamiento y seguimiento de pacientes con cáncer diferenciado de tiroides. RAEM 2014, 51:85.

2) GHARIB H, PAPINI E, PASCHKE R, et al. American Association of Clinical Endocrinologists, Associazione Medici Endocrinologi, and European Thyroid Association medical guidelines for clinical practice for the diagnosis and management of thyroid nodules. Endocr Pract 2010; 16:1.

3) PACINI F, CASTAGNA M, BRILLI L, et al. Thyroid Cancer: ESMO Clinical Practice Guidelines for diagnosis, treatment and follow-up. Ann of Oncol 2012; 23:111.

4) COOPER D, DOHERTY G, HAUGEN B, et al. Revised American Thyroid Association management guidelines for patients with thyroid nodules and differentiated thyroid cancer. Thyroid 2009; 19:1167.

5) ROSÁRIO P, WARD L, CARVALHO G, et al. Thyroid nodules and differentiated thyroid cancer: update on the Brazilian consensus. Arq Bras Endocrinol Metab 2013; 57:240.

6) CAMARGO R, CORIGLIANO S, FRIGUGLIETTI C, et al. Latin American Thyroid Society recommendations for the management of thyroid nodules. Arq Bras Endocrinol Metab 2009; 53:116.

7) RUSS G, ROYER B, BIGORGNE C, et al. Prospective evaluation of thyroid imaging reporting and data system (TIRADS) on 4550 nodules with and without elastography. Eur J Endocrinol 2013; 168:649.

8) ROSARIO PW, PURISCH S. Ultrasonographic characteristics as a criterion for repeat cytology in benign thyroid nodules. Arq Bras Endocrinol Metabol. 2010;54:52-5.

9) MAIA F, MATOS P, PAVIN E, et al. Value of repeat ultrasound-guided fine-needle aspiration in thyroid nodule with a first benign cytologic result: impact of ultrasound to predict malignancy. Endocrine 2011; 40:290.

10) KWAK J, KIM E. Ultrasound elastography for thyroid nodules: recent advances. Ultrasonography 2014; 33:75.

11) CIBAS E, ALIS S. The Bethesda System for reporting thyroid cytopathology. Thyroid 2009; 19:1159.

12) NARDI F, BASOLO F, CRESCENZI A, et al. Italian consensus for the classification and reporting of thyroid cytology. J Endocrinol Invest 2014; 37:593.

13) KAKUDO K, KAMEYAMA K, MIYAUCHI A, et al. Introducing the reporting system for thyroid fine-needle aspiration cytology according to the new guidelines of the Japan Thyroid Association. Endocrine Journal 2014; 61:539.

14) MATOS P, FERREIRA A, FACURI F, et al. Usefulness of HBME-1, cytokeratin 19 and galectin-3 immunostaining in the diagnosis of thyroid malignancy. Histopathology 2005; 47:391. 
15) SALEH HA, FENG J, TABASSUM F, et al. Differential expression of galectin-3, CK19, HBME1, and Ret oncoprotein in the diagnosis of thyroid neoplasms by fine needle aspiration biopsy. Cytojournal 2009; 6:18.

16) NIKIFOROV Y, OHORI N, HODAK S, et al. Impact of mutational testing on the diagnosis and management of patients with cytologically indeterminate thyroid nodules: a prospective analysis of 1056 FNA samples. J Clin Endocrinol Metab 2011; 96:3390.

17) FERRAZ C, ESZLINGER M, PASCHKE R. Current state and future perspective of molecular diagnosis of fineneedle aspiration biopsy of thyroid nodules. J Clin Endocrinol Metab 2011; 96:2016.

18) SHEN R, LIYANARACHCHI S, LI W, et al. MicroRNA signature in thyroid fine needle aspiration cytology applied to "atypia of undetermined significance" cases. Thyroid 2012; 22:9.

19) ALEXANDER E, KENNEDY G, BALOCH Z, et al. Preoperative diagnosis of benign thyroid nodules with indeterminate cytology. N Engl J Med 2012; 367:705.

20) CAPPOLA A, MANDEL S. Molecular testing in thyroid cancer: BRAF mutation status and mortality. JAMA 2013; 309:1529.

21) DERDAS S, SOULITZIS N, BALIS V, et al. Expression analysis of B-Raf oncogene in V600E-negative benign and malignant tumors of the thyroid gland: correlation with late disease onset. Med Oncol 2013; 30:336.

22) SYRENICZ A, KOZIOŁEK M, CIECHANOWICZ A, et al. New insights into the diagnosis of nodular goiter. Thyroid Research 2014, 7:6

23) SMITH P, SALOMONE L, HANKS J. Thyroid. En TOWNSEND C, BEAUCHAMP R, EVERS R, et al. Sabiston Textbook of Surgery: the biological basis of modern surgical practice. 19th ed. Cap 38. Elsevier Saunders, Philadelphia 2012.

24) LAL G, CLARK O. Tiroides, paratiroides y suprarrenales. En BRUNICARDI C, ANDERSEN D, BILLIAR T, et al. Schwartz. Principios de Cirugía. 9o ed. Cap 38. McGraw-Hill Interamericana Editores, México 2010.

25) MAITRA A. Sistema endocrino. En KUMAR V, ABBAS A, FAUSTO N, et al. Robbins y Cotran. Patología estructural y funcional. 8o ed. Cap 24. Elsevier España, Barcelona 2010.

26) IKEDA Y, TAKAMI H, SASAKI Y, et al. Endoscopic neck surgery by the axillary approach. J A Coll Surg 2000; 191:336.

27) PALAZZO F, SEBAGF, HENRY F. Endocrine surgical technique: endoscopic thyroidectomy via the lateral approach. Surg Endosc 2006; 20:339.

28) MICCOLI P, BERTI P, FRUSTACI G, et al. Video-assisted thyroidectomy: indications and results. Langenbecks Arch Surg 2006; 391:68.

29) KANG S, LEE S, LEE S, et al. Robotic thyroid surgery using a gasless, transaxillary approach and the da Vinci $S$ system: the operative outcomes of 338 consecutive patients. Surgery 2009; 146:1048.

30) KUPPERSMITH R, HOLSINGER F. Robotic thyroid surgery: an initial experience with North American patients. Laryngoscope $2011 ; 121: 521$.

31) VENKAT R, GUERRERO M. Recent advances in the surgical treatment of differentiated thyroid cancer: a comprehensive review. Scientific World Journal. 2013; 2013:425136. 
32) MORRISON A, SUH H, HODIN A. The surgical management of thyroid cancer. Rambam Maimonides Med J. 2014 Apr 28; 5(2):e0008.

33) HAYMART MR, BANERJEE M, YANG D, et al. Variation in the management of thyroid cancer. J Clin Endocrinol Metab 2013; 98:2001.

34) PAPALEONTIOU M, HAYMART M. New insights in risk stratification of differentiated thyroid cancer Curr Opin Oncol 2014; 26:1.

35) TUTTLE R, TALA H, SHAH J, et al. Estimating risk of recurrence in differentiated thyroid cancer after total thyroidectomy and radioactive iodine remnant ablation: using response to therapy variables to modify the initial risk estimates predicted by the new American Thyroid Association staging system. Thyroid 2010; 20:1341.

36) PITOIA F, BUENO F, URCLUOLI C, et al. Outcome of patients with differentiated thyroid cancer risk stratified according to the American Thyroid Association and Latin-American Thyroid Society risk of recurrence classification systems. Thyroid 2013; 23:1401.

37) NIXON IJ, GANLY I, PATEL SG, et al. The results of selective use of radioactive iodine on survival and on recurrence in the management of papillary thyroid cancer, based on Memorial Sloan-Kettering Cancer Center risk group stratification. Thyroid 2013; 23:683.

38) GHARIB H, HEGEDÜS L, PACELLA C, et al. Clinical review: Nonsurgical, image-guided, minimally invasive therapy for thyroid nodules. J Clin Endocrinol Metab 2013; 98:3949.

39) JONG J, KANG S, YUN J, et al. Comparative study of endoscopic thyroidectomy versus conventional open thyroidectomy in papillary thyroid microcarcinoma (PTMC) patients. J Surg Oncol 2009; 100:477.

40) DI J, ZHANG H, HAN X, et al. Minimally invasive video-assisted thyroidectomy for accidental papillary thyroid microcarcinoma: comparison with conventional open thyroidectomy with 5 years follow-up. Chin Med $2011 ; 124 ; 3293$.

41) KIM W, KIM J, HUR S, et al. Is robotic surgery superior to endoscopic and open surgeries in thyroid cancer? World J Surg 2011; 35:779.

42) LEE J, LEE J, NAH K, et al. Comparison of endoscopic and robotic thyroidectomy. Ann Surg Oncol 2011; 18 : 1439.

43) CHUNG Y, CHOE J, KANG K, et al. Endoscopic thyroidectomy for thyroid malignancies: comparison with conventional open thyroidectomy. World J Surg 2007; 31:2302.

44) GLOVER R, GUNDARA S, NORLÉN O, et al. The pros and cons of prophylactic central neck dissection in papillary thyroid carcinoma. Gland Surg 2013; 2:196.

45) CHAN A, LANG B, WONG K. The pros and cons of routine central compartment neck dissection for clinically nodal negative (cNO) papillary thyroid cancer. Gland Surg 2013; 2:186.

46) KENDALL-TAYLOR P. The UK Evidence-Based guidelines for the management of thyroid cancer: key recommendations. En MAZZAFERRI E, HARMER C, MALLICK U, et al. Practical management of thyroid cancer. Cap 2. Springer-Verlag, London 2006.

47) MALLICK U. Thyroid cancer multidisciplinary team and the organisational paradigm. En MAZZAFERRI E, HARMER C, MALLICK U, et al. Practical management of thyroid cancer. Cap 3. Springer-Verlag, London 2006. 
48) CARTY S, DOHERTY G, INABNET III W, et al. American Thyroid Association Statement on the essential elements of interdisciplinary communication of perioperative information for patients undergoing thyroid cancer surgery. Thyroid 2012; 22:395.

49) ROSENTHAL M. Ethical issues in the management of thyroid disease. Endocrinol Metab Clin North Am 2014; 43:545.

50) RODRÍGUEZ H. Seudoconsentimiento informado en Uruguay. Rev Med Urug 2002; 18:89.

51) GONZÁLEZ D, RODRÍGUEZ H, BERRO G. Consentimiento informado. Análisis crítico de su aplicación en un servicio quirúrgico. Rev Med Uruguay 2005; 21:291.

52) PERINETTI H, VIA E. Complicaciones en la cirugía tiroidea: nervio recurrente y glándula paratirodea. Rev Arg Cir 1988; 54:69.

53) CASTRO M, GHARIB H. Thyroid diseasse. En CAMACHO P, GHARIB H, SIZEMORE G. Evidence-based endocrinology. 3ํrd. Cap 2. Lippincott William \& Wilkins. Philadelphia 2012.

54) FÜHRER D, BOCKISCH A, SCHMID KW. Euthyroid goiter with and without nodules-diagnosis and treatment. Dtsch Arztebl Int 2012; 109:506.

55) PERROS P. Thyroid nodules. En: MAZZAFERRI E, HARMER C, MALLICK U, et al. Practical Management of Thyroid Cancer. Cap 7. Springer-Verlag, London 2006.

56) SUZUKI S, FUKUNARI N, KAMEYAMA K, et al. How is the natural history of nodules diagnosed as benign (growth and reduction rates)? En TAKAMI H, ITO Y, NOGUCHI H, et al. Treatment of thyroid tumor. Cap 10. Springer Japan, Tokyo 2013.

57) ALEXANDER E, HURWITZ S, HEERING J, et al. Natural history of benign solid and cystic thyroid nodules. Ann Intern Med 2003; 138:315.

58) KUMA K, MATSUZUKA F, KOBAYASHI A, et al. Outcome of long standing solitary thyroid nodules. World J Sur $1992 ; 16: 583$.

59) SUZUKI S, FUKUNARI N, KAMEYAMA K, et al. Does TSH suppression therapy reduce the size of tumors diagnosed as benign? En TAKAMI H, ITO Y, NOGUCHI H, et al. Treatment of thyroid tumor. Cap 11. Springer Japan, Tokyo 2013.

60) YOUSEF A, CLARK J, DOI S. Thyroxine suppression therapy for benign, non-functioning solitary thyroid nodules: a quality-effects meta-analysis. Clin Med Res. 2010; 8:150.

61) BANDEIRA-ECHTLER E, BERGERHOFF K, RICHTER B. Levothyroxine or minimally invasive therapies for benign thyroid nodules. Cochrane Database Syst Rev. 2014; 6:CD004098.

62) BONNEMA S, HEGEDÜS L. Radioiodine therapy in benign thyroid diseases: effects, side effects, and factors affecting therapeutic outcome. Endocr Rev 2012; 33:920.

63) BAHN R, BURCH H, COOPER D, et al. Hyperthyroidism and other causes of thyrotoxicosis: management guidelines of the American Thyroid Association and American Association of Clinical Endocrinologists. Endocr Pract $2011 ; 17: 456$.

64) NYGAARD B, HEGEDÜS L, NIELSEN K, et al. Longterm effect of radioactive iodine on thyroid function and size in patients with solitary autonomously functioning toxic thyroid nodules. Clin Endocrinol 1999; 50:197. 
65) VILLADSEN MJ, SØRENSEN CH, GODBALLE C, et al. Need for thyroidectomy in patients treated with radioactive iodide for benign thyroid disease. Dan Med Bull. 2011; 58:A4343.

66) LEE S, AHN I. Effectiveness of percutaneous ethanol injection therapy in benign nodular and cystic thyroid diseases: long-term follow-up experience. Endocr J 2005; 52:455.

67) SUZUKI S, FUKUNARI N, KAMEYAMA K, et al. What is the efficacy of percutaneous ethanol injection therapy for autonomously functioning thyroid nodules? En TAKAMI H, ITO Y, NOGUCHI H, et al. Treatment of thyroid tumor. Cap 13. Springer Japan, Tokyo 2013.

68) SUZUKI S, FUKUNARI N, KAMEYAMA K, et al. Do cystic nodules decrease in volume by aspiration and drainage of content fluid and percutaneous ethanol injection therapy? En TAKAMI H, ITO Y, NOGUCHI H, et al. Treatment of thyroid tumor. Cap 14. Springer Japan, Tokyo 2013.

69) VALCAVI R, FRASOLDATI A. Ultrasound-guided percutaneous ethanol injection therapy in thyroid cystic nodules. Endocr Pract 2004; 10:269.

70) BENNEDBAEK FN, HEGEDÜS L. Treatment of recurrent thyroid cysts with ethanol: a randomized double-blind controlled trial. J Clin Endocrinol Metab 2003; 88:5773.

71) HA E, BAEK J, LEE J. The efficacy and complications of radiofrequency ablation of thyroid nodules. Curr Opin Endocrinol Diabetes Obes 2011; 18:310.

72) WONG K, LANG B. Use of radiofrequency ablation in benign thyroid nodules:a literature review and updates. Int J Endocrinol 2013; 2013:428363.

73) BAEK J, LEE J, SUNG J, et al. Complications encountered in the treatment of benign thyroid nodules with USguided radiofrequency ablation: a multicenter study. Radiology 2012; 262:335.

74) SUNG J, BAEK J, KIM K, et al. Single-session treatment of benign cystic thyroid nodules with ethanol versus radiofrequency ablation: a prospective randomized study. Radiology 2013; 269:293.

75) PAPINI E, RAGO T, GAMBELUNGHE G, et al. Long-term efficacy of ultrasound-guided laser ablation for benign solid thyroid nodules. results of a three-year multicenter prospective randomized trial. J Clin Endocrinol Metab 2014 Jul 22:jc20141826.

76) PAPINI E, BIZZARRI G, PACELLA C, et al. Percutaneous laser ablation of benign and malignant thyroid nodules. Curr Opin Endocrinol Diabetes Obes. 2008; 15:434.

77) SHIN J, BAEK J, HA E, et al. Radiofrequency ablation of thyroid nodules: basic principles and clinical application. Int J Endocrinol. 2012; 2012:919650. doi: 10.1155/2012/919650.

78) GUENETTE J, MONCHIK J, DUPUY D. Image-guided ablation of postsurgical locoregional recurrence of biopsyproven well-differentiated thyroid carcinoma. J Vasc Interv Radiol 2013; 24:672.

79) BAEK J, KIM Y, SUNG J, et al. Locoregional control of metastatic well-differentiated thyroid cancer by ultrasound-guided radiofrequency ablation. AJR Am J Roentgenol 2011; 197:W331.

80) MCKEE S, WU H, WANG $X$, et al. Hürthle cell neoplasms diagnosed by fine needle aspiration are not associated with an increased risk of malignancy. Acta Cytol 2014; 58:235.

81) PU R, YANG J, WASSERMAN P, et al. Does Hurthle cell lesion/neoplasm predict malignancy more than follicular lesion/neoplasm on thyroid fine-needle aspiration? Diagn Cytopathol 2006; 34:330. 
82) CONZO G, CALÒ P, GAMBARDELLA C, et al. Controversies in the surgical management of thyroid follicular neoplasms. Retrospective analysis of 721 patients. Int J Surg 2014; 12S1:S29.

83) CALÒ P, MEDAS F, SANTA CRUZ R, et al. Follicular nodules (Thy3) of the thyroid: is total thyroidectomy the best option? BMC Surg 2014; 14:12.

84) KAHMKE R, LEE W, PUSCAS L, et al. Utility of intraoperative frozen sections during thyroid surgery. Int J Otolaryngol 2013; 2013:496138.

85) ANTIC T, TAXY J. Thyroid frozen section: supplementary or unnecessary? Am J Surg Pathol. 2013; 37:282.

86) CETIN B, ASLAN S, HATIBOGLU C, et al. Frozen section in thyroid surgery: is it a necessity? Can J Surg 2004; 47:29.

87) LIU F, LIOU M, HSUEH C, et al. Thyroid follicular neoplasm: analysis by fine needle aspiration cytology, frozen section, and histopathology. Diagn Cytopathol 2010; 38:801.

88) LIVOLSI VA ${ }^{1}$, BALOCH ZW. Use and abuse of frozen section in the diagnosis of follicular thyroid lesions. Endocr Pathol 2005; 16:285.

89) BASOLO F, UGOLINI C, PROIETTI A, et al. Role of frozen section associated with intraoperative cytology in comparison to FNA and FS alone in the management of thyroid nodules. Eur J Surg Oncol 2007; 33:769.

90) CIMARRA L y col. Cáncer de tiroides en general. Carcinomas diferenciados: carcinoma papilar y carcinoma folicular. En: Diagnóstico y tratamiento de las enfermedades quirúrgicas de la glándula tiroides. Cap 5. Oficina del Libro FEFMUR, Montevideo 2006.

91) MAZZAFERRI E. An overview of the management of thyroid cancer En: MAZZAFERRI E, HARMER C, MALLICK U, et al. Practical management of thyroid cancer. Cap 1. Springer-Verlag, London 2006.

92) VILLARET D, MAZZAFERRI E. Initial thyroid surgery for patient with differentiated thyroid carcinoma. En: MAZZAFERRI E, HARMER C, MALLICK U, et al. Practical management of thyroid cancer. Cap 12. Springer-Verlag, London 2006.

93) BILIMORIA K, BENTREM D, KO C, et al. Extent of surgery affects survival for papillary thyroid cancer. Ann Surg $2007 ; 246: 375$.

94) Thyroid. En: EDGE S, BYRD D, COMPTON C, et al. AJCC Cancer Staging Manual. 7th ed. New York, NY: Springer, $2010,87$.

95) NIXON I, SHAHA A, PATEL S, et al. Surgical diagnosis. Frozen section and the extent of surgery. Otolaryngol Clin N Am 2014, 47:519.

96) LUSTER M, WEBER T, VERBURG F. Differentiated thyroid cancer-personalized therapies to prevent overtreatment. Nat Rev Endocrinol 2014; 10:563.

97) KAMMORI M, FUKUMORI T, SUGISHITA Y, et al. Therapeutic strategy for low-risk thyroid cancer in Kanaji Thyroid Hospital Endocr J 2014; 61:1.

98) TAKAMI H, ITO Y, OKAMOTO T, et al. Revisiting the guidelines issued by the Japanese Society of Thyroid Surgeons and Japan Association of Endocrine Surgeons: a gradual move towards consensus between Japanese and western practice in the management of thyroid carcinoma. World J Surg 2014; 38:2002. 
99) IMAI T, KITANO H, SUGITANI I, et al. When can papillary microcarcinoma (papillary carcinoma measuring 1 $\mathrm{cm}$ or less) be observed without immediate surgery? En TAKAMI H, ITO Y, NOGUCHI H, et al. Treatment of thyroid tumor. Cap 20. Springer Japan, Tokyo 2013.

100) ITO Y, MIYAUCHI A, KIHARA M, et al. Patient age is significantly related to the progression of papillary microcarcinoma of the thyroid under observation. Thyroid 2014; 24:27.

101) PAPINI E, GUGLIELMI R, GHARIB H, et al. Ultrasound-guided laser ablation of incidental papillary thyroid microcarcinoma: a potential therapeutic approach in patients at surgical risk. Thyroid $2011 ; 21: 917$.

102) NA D, LEE J, JUNG S, et al. Radiofrequency ablation of benign thyroid nodules and recurrent thyroid cancers: consensus statement and recommendations. Korean J Radiol 2012; 13:117.

103) PACELLA C, PAPINI E. Image-guided percutaneous ablation therapies for local recurrences of thyroid tumors. J Endocrinol Invest 2013; 36:61.

104) PAPINI E, BIZZARRI G, BIANCHINI A, et al. Percutaneous ultrasound-guided laser ablation is effective for treating selected nodal metastases in papillary thyroid cancer. J Clin Endocrinol Metab 2013; 98:E92.

105) CARON N, STURGEON C, CLARK O. The specialist endocrine surgeon. En: MAZZAFERRI E, HARMER C, MALLICK $\mathrm{U}$, et al. Practical management of thyroid cancer. Cap 11. Springer-Verlag, London 2006.

106) CIMARRA L y col. Tiroidectomía y vaciamientos ganglionares, Táctica y técnica quirúrgica. En: Diagnóstico y tratamiento de las enfermedades quirúrgicas de la glándula tiroides. Cap 5. Oficina del Libro FEFMUR, Montevideo 2006.

107) PARDAL J, CUELLO J, SANTIAGO L. Development of a checklist in risk management in thyroidectomy. Endocrinol Nutr 2014; pii: S1575-0922(14)00139-9.

108) TERRIS D, SNYDER S, CARNEIRO-PLA D, et al. American Thyroid Association statement on outpatient thyroidectomy. Thyroid 2013; 23:1193.

109) SÁNCHEZ J, RECIO G, GUEROLA A, et al. Tiroidectomía en régimen de cirugía mayor ambulatoria. Estudio prospectivo. Cir Esp 2006; 80:206.

110) DORAN H, ENGLAND J, PALAZZO F. Questionable safety of thyroid surgery with same day discharge. Ann R Coll Surg Engl 2012; 94:543.

111) ELISHA S, BOYTIM M, BORDI S, et al. Anesthesia case management for thyroidectomy. AANA J 2010; 78:151.

112) LENNARD T. Complications of thyroid surgery. En: MAZZAFERRI E, HARMER C, MALLICK U, et al. Practical management of thyroid cancer. Cap 14. Springer-Verlag, London 2006.

113) DUKE W, CHAUNG K, TERRIS D. Contemporary surgical techniques. Otolaryngol Clin N Am 2014; 47:529.

114) PHITAYAKORN R. Minimally invasive thyroidectomy for thyroid carcinoma En: LINOS D, CHUNG W. Minimally invasive thyroidectomy. Cap 22. Springer-Verlag Berlin 2012.

115) MICCOLI P, MATERAZZI G. Minimally invasive video-assisted thyroidectomy. En: LINOS D, CHUNG W. Minimally invasive thyroidectomy. Cap 9. Springer-Verlag Berlin 2012.

116) LINOS D. Minimally invasive non-endoscopic thyroidectomy: The MINET approach. En: LINOS D, CHUNG W. Minimally invasive thyroidectomy. Cap 11. Springer-Verlag Berlin 2012. 
117) ALESINA P, ROLFS T, RUHLAND K, et al. Evaluation of postoperative pain after minimally invasive video-assisted and conventional thyroidectomy: results of a prospective study. ESES Vienna presentation. Langenbecks Arch Surg 2010; 395:845.

118) MICCOLI P, MINUTO M, UGOLINI C, et al. Minimally invasive video-assisted thyroidectomy for benign thyroid disease: an evidence-based review. World J Surg 2008; 32:1333.

119) SGOURAKIS G, SOTIROPOULOS G, NEUHAUSER M, et al. Comparison between minimally invasive video-assisted thyroidectomy and conventional thyroidectomy: is there any evidence-based information? Thyroid 2008; 18:721.

120) GROGAN R, DUH Q. Conventional thyroidectomy versus MIT: An Outcome Analysis. En: LINOS D, CHUNG W. Minimally invasive thyroidectomy. Cap 23. Springer-Verlag Berlin 2012.

121) MICCOLI P, PINCHERA A, MATERAZZI G, et al. Surgical treatment of low- and intermediate-risk papillary thyroid cancer with minimally invasive video-assisted thyroidectomy. J Clin Endocrinol Metab 2009; 94:1618.

122) ECONOMOPOULOS K, LINOS D. Endoscopic thyroidectomy in the neck. En: LINOS D, CHUNG W. Minimally invasive thyroidectomy. Cap 9. Springer-Verlag Berlin 2012.

123) CHEN D, DING K, GUO K, et al. Gasless single incision endoscopic thyroidectomy. JSLS 2012; 16:60.

124) WRIGHT S. Endoscopic transaxillary thyroidectomy. En: LINOS D, CHUNG W. Minimally invasive thyroidectomy. Cap 12. Springer-Verlag Berlin 2012.

125) LINOS D. Endoscopic thyroidectomy using the gasless transaxillary approach. En: LINOS D, CHUNG W. Minimally invasive thyroidectomy. Cap 13. Springer-Verlag Berlin 2012.

126) KANG S, JEONG J, YUN J, et al. Gasless endoscopic thyroidectomy using trans-axillary approach; surgical outcome of 581 patients. Endocr J 2009; 56:361.

127) SOONMIN D, DUGAL N. Complications of minimally invasive thyroidectomy. En: LINOS D, CHUNG W. Minimally invasive thyroidectomy. Cap 22. Springer-Verlag Berlin 2012.

128) RABINOVICS N, FEINMESSER R, AIDAN P, et al. Robot-assisted transaxillary thyroid surgery-feasibility and safety of a novel technique. Rambam Maimonides Med J 2014; 5:e0013.

129) CHUNG W. Robotic gasless transaxillary thyroidectomy. En: LINOS D, CHUNG W. Minimally invasive thyroidectomy. Cap 14. Springer-Verlag Berlin 2012.

130) LANG B, WONG C, TSANG J, et al. A systematic review and meta-comparing surgically-related complications between robotic-assisted thyroidectomy and conventional open thyroidectomy. Ann Surg Oncol 2014; 21:850.

131) JACKSON N, YAO L, TUFANO R, et al. Safety of robotic thyroidectomy approaches: meta-analysis and systematic review. Head Neck 2014; 36:137.

132) LEE J, KANG S, JUNG J, et al. Multicenter study of robotic thyroidectomy: short-term postoperative outcomes and surgeon ergonomic considerations. Ann Surg Oncol 2011; 18:2538.

133) SANCHO J, SITGES-SERRA A. Técnica y complicaciones de la tiroidectomía y de la paratiroidectomía. En: PARRILLA P, LANDA J. Cirugía AEC. Cap 84. Editorial Médica Panamericana Madrid 2010.

134) PÉREZ J, VENTURELLI F. Complicaciones de la cirugía tiroidea. Cuad Cir 2007; 21:84.

135) VARALDO E, ANSALDO G, MASCHERINI M, et al. Neurological complications in thyroid surgery: a surgical point of view on laryngeal nerves. Front Endocrinol 2014; 5:108. 
136) CALÒ P, PISANO G, MEDAS F, et al. Identification alone versus intraoperative neuromonitoring of the recurrent laryngeal nerve during thyroid surgery: experience of 2034 consecutive patients. J Otolaryngol Head Neck Surg 2014; 43:16.

137) PISANU A, PORCEDDU G, PODDA M, et al. Systematic review with meta-analysis of studies comparing intraoperative neuromonitoring of recurrent laryngeal nerves versus visualization alone during thyroidectomy. J Surg Res 2014; 188:152.

138) HAYWARD N, GRODSKI S, YEUNG M, et al. Recurrent laryngeal nerve injury in thyroid surgery: a review. ANZ J Surg 2013; 83:15.

139) TESTINI M, NACCHIERO M, PICCINNI G, et al. Total thyroidectomy is improved by loupe magnification. Microsurgery $2004 ; 24: 39$.

140) DÍEZ M, SÁNCHEZ J, SÁNCHEZ-SECO M, et al. Determinación de paratirina en suero como factor predictivo de hipocalcemia tras tiroidectomía total. Cir Esp 2009; 85:96.

141) LANG B, YIH P, NG K. A prospective evaluation of quick intraoperative parathyroid hormone assay at the time of skin closure in predicting clinically relevant hypocalcemia after thyroidectomy. World J Surg 2012; $36: 1300$

142) ITO Y, MIYAUCHI A, KOBAYASHI K, et al. Static and dynamic prognostic factors of papillary thyroid carcinoma [Review]. Endocr J 2014; doi: 10.1507/endocrj. EJ14-0303.

143) ITO Y, MIYAUCHI A, KIHARA M, et al. Prognostic values of clinical lymph node metastasis and macroscopic extrathyroid extension in papillary thyroid carcinoma [Review]. Endocr J 2014; 61:745.

144) VAISMAN F, MOMESSO D, BULZICO D, et al. Thyroid lobectomy is associated with excellent clinical outcomes in properly selected differentiated thyroid cancer patients with primary tumors greater than $1 \mathrm{~cm}$. J Thyroid Res 2013; 2013:398194.

145) COSTA A, HERRERO A, FRESNO $M$, et al. BRAF mutation associated with other genetic events identifies a subset of aggressive papillary thyroid carcinoma. Clin Endocrinol 2008; 68:618.

146) SUGINO K, KAMEYAMA K, NAGAHAMA M, et al. Does completion thyroidectomy improve the outcome of patients with minimally invasive follicular carcinoma of the thyroid? Ann Surg Oncol 2014; 21:2981.

147) PHITAYAKORN R, MCHENRY CR. Follicular and Hurthle cell carcinoma of the thyroid gland. Surg Oncol Clin N Am 2006; 15:603.

148) STACK B, FERRIS R, GOLDENBERG D, et al. American Thyroid Association consensus review and statement regarding the anatomy, terminology, and rationale for lateral neck dissection in differentiated thyroid cancer. Thyroid 2012; 22:501.

149) CARTY SE, COOPER DS, DOHERTY GM, et al. Consensus statement on the terminology and classification of central neck dissection for thyroid cancer. Thyroid. 2009; 19:1153.

150) GIUGLIANO G, PROH M, GIBELLI B, et al. Central neck dissection in differentiated thyroid cancer: technical notes. Acta Otorhinolaryngol Ital 2014; 34:9.

151) RAFFAELLI M, DE CREA C, SESSA L, et al. Can intraoperative frozen section influence the extension of central neck dissection in cNO papillary thyroid carcinoma? Langenbecks Arch Surg 2013; 398:383. 
152) RAIJMAKERS P, PAUL M, LIPS P. Sentinel node detection in patients with thyroid carcinoma: a meta-analysis. World J Surg 2008; 32:1961.

153) JOZAGHI Y, RICHARDSON K, ANAND S, et al. Frozen section analysis and sentinel lymph node biopsy in well differentiated thyroid cancer. J Otolaryngol Head Neck Surg 2013; 42:48.

154) WATKINSON J. Management of cervical lymph nodes in differentiated thyroid cancer. En: MAZZAFERRI E, HARMER C, MALLICK U, et al. Practical management of thyroid cancer. Cap 13. Springer-Verlag, London 2006.

155) SCHOPPY D, HOLSINGER F. Management of the Neck in Thyroid Cancer. Otolaryngol Clin N Am 2014; 47:545.

156) WANG L, VERSNICK M, GILL A, et al. Level VII is an important component of central neck dissection for papillary thyroid cancer. Ann Surg Oncol 2013; 20:2261.

157) McHENRY C, STULBeRG J. Prophylactic Central Compartment Neck Dissection for Papillary Thyroid Cancer. Surg Clin N Am 94 (2014) 529-

158) WANG T, CHEUNG K, FARROKHYAR F, et al. A Meta-analysis of the effect of prophylactic central compartment neck dissection on locoregional recurrence rates in patients with papillary thyroid cancer. Ann Surg Oncol 2013; 20:3477.

159) GIORDANO D, VALCAVI R, THOMPSON GB, et al. Complications of central neck dissection in patients with papillary thyroid carcinoma: results of a study on 1087 patients and review of the literature. Thyroid 2012; 22:911.

160) HENRY J, GRAMATICA L, DENIZOT A, et al. Morbidity of prophylactic lymph node dissection in the central neck area in patients with papillary thyroid carcinoma. Langenbecks Arch Surg. 1998; 383:167.

161) PARK J, ROH J, LEE J, et al. Risk factors for central neck lymph node metastasis of clinically noninvasive, nodenegative papillary thyroid microcarcinoma. Am J Surg. 2014; 208:412.

162) SANCHO J, LENNARD T, PAUNOVIC I, et al. Prophylactic central neck disection in papillary thyroid cancer: a consensus report of the European Society of Endocrine Surgeons (ESES) Langenbecks Arch Surg 2014; 399:155.

163) MOO T, UMUNNA B, KATO M, et al. Ipsilateral versus bilateral central neck lymph node dissection in papillary thyroid carcinoma. Ann Surg 2009; 250:403.

164) RAFFAELLI M, DE CREA C, SESSA L, et al. Prospective evaluation of total thyroidectomy versus ipsilateral versus bilateral central neck dissection in patients with clinically node-negative papillary thyroid carcinoma. Surgery 2012; 152:957.

165) LEE J, KOO B. The prognostic implication and potential role of BRAF mutation in the decision to perform elective neck dissection for thyroid cancer. Gland Surgery 2013; 2:206.

166) TANG C, YANG L, WANG N, et al. High expression of GPER1, EGFR and CXCR1 is associated with lymph node metastasis in papillary thyroid carcinoma. Int J Clin Exp Pathol 2014; 7:3213.

167) IMAI T, KITANO H, SUGITANI I, et al. Does dissection of the lateral compartment improve the prognosis of papillary carcinoma patients? En TAKAMI H, ITO Y, NOGUCHI H, et al. Treatment of thyroid tumor. Cap 19. Springer Japan, Tokyo 2013. 


\section{Tablas y figuras}

\begin{tabular}{|l|l|l|l|l|l|l|l|}
\hline & TNM & EORTC & AMES & AGES & MACIS & NTCTCS & MSK \\
\hline EDAD & $\mathrm{x}$ & $\mathrm{x}$ & $\mathrm{x}$ & $\mathrm{x}$ & $\mathrm{x}$ & $\mathrm{x}$ & $\mathrm{x}$ \\
\hline SEXO & & $\mathrm{x}$ & $\mathrm{x}$ & & & & \\
\hline TIPO CELULAR & $\mathrm{x}$ & $\mathrm{x}$ & & & & & \\
\hline TAMAÑO & $\mathrm{x}$ & & $\mathrm{x}$ & $\mathrm{x}$ & $\mathrm{x}$ & $\mathrm{x}$ & \\
\hline GRADO HISTOLÓGICO & & & & $\mathrm{x}$ & & & $\mathrm{x}$ \\
\hline EXTENSIÓN EXTRATIROIDEA & $\mathrm{x}$ & $\mathrm{x}$ & $\mathrm{x}$ & $\mathrm{x}$ & $\mathrm{x}$ & $\mathrm{x}$ & $\mathrm{x}$ \\
\hline METÁSTASIS GANGLIONARES & $\mathrm{x}$ & & & & & $\mathrm{x}$ & \\
\hline METÁSTASIS DISTANTES & $\mathrm{x}$ & $\mathrm{x}$ & $\mathrm{x}$ & $\mathrm{x}$ & $\mathrm{x}$ & $\mathrm{x}$ & $\mathrm{x}$ \\
\hline
\end{tabular}

Tabla 1 - Factores pronósticos considerados en los principales sistemas empleados. 


\begin{tabular}{|c|l|}
\hline TX & No se puede evaluar un tumor primario. \\
\hline T0 & No hay prueba de tumor primario. \\
\hline T1 & El tumor mide $\leq 2 \mathrm{~cm}$ en su dimensión mayor y se limita a la tiroides. \\
\hline T1a & El tumor mide $\leq 1 \mathrm{~cm}$ y se limita a la tiroides. \\
\hline T1b & El tumor mide $>1 \mathrm{~cm}$, pero $\leq 2 \mathrm{~cm}$ en su dimensión mayor y se limita a la tiroides. \\
\hline T2 & El tumor mide $>2 \mathrm{~cm}$, pero $\leq 4$ cm en su dimensión mayor y se limita a la tiroides. \\
\hline T3 & $\begin{array}{l}\text { El tumor mide }>4 \text { cm en su dimensión mayor o cualquier tumor con diseminación mínima } \\
\text { fuera de la tiroides (por ejemplo, diseminación hasta el músculo esternotiroideo o los te- } \\
\text { jidos blandos alrededor de la tiroidea). }\end{array}$ \\
\hline T4a & Enfermedad moderadamente avanzada. \\
\cline { 2 - 3 } & $\begin{array}{l}\text { El tumor es de cualquier tamaño y se extiende más allá de la cápsula tiroidea hasta invadir } \\
\text { los tejidos blandos subcutáneos, la laringe, la tráquea, el esófago o el nervio laríngeo re- } \\
\text { currente. }\end{array}$ \\
\hline T4b & Enfermedad muy avanzada. \\
\cline { 2 - 3 } & $\begin{array}{l}\text { El tumor invade la fascia prevertebral o envuelve la arteria carótida o los vasos mediastí- } \\
\text { nicos. }\end{array}$ \\
\hline cT4a & Carcinoma anaplásico intratiroideo. \\
\hline cT4b & Carcinoma anaplásico con diseminación extratiroidea macroscópica. \\
\hline NX & No se pueden evaluar los ganglios linfáticos regionales. \\
\hline N0 & No hay metástasis en los ganglios linfáticos regionales. \\
\hline N1 & Metástasis en los ganglios linfáticos regionales. \\
\hline N1a & $\begin{array}{l}\text { Metástasis hasta Nivel IV (ganglios linfáticos pretraqueales, paratraqueales, y prelaríngeos } \\
\text { o delfianos). }\end{array}$ \\
\hline N1b & $\begin{array}{l}\text { Metástasis en los ganglios cervicales unilaterales, bilaterales o contralaterales (niveles I, II, } \\
\text { III, IV o V) o en los ganglios linfáticos retrofaríngeos o mediastínicos superiores (Nivel VII). }\end{array}$ \\
\hline M1 & No hay metástasis a distancia. \\
\hline
\end{tabular}

Tabla 2 - Características patológicas TNM (93) 


\begin{tabular}{|c|c|c|c|}
\hline Estadio & $\mathrm{T}$ & $\mathrm{N}$ & M \\
\hline \multicolumn{4}{|c|}{ Papilar o folicular (diferenciado) } \\
\hline \multicolumn{4}{|c|}{45 AÑOS } \\
\hline 1 & Cualquier T & Cualquier N & M0 \\
\hline II & Cualquier T & Cualquier N & M1 \\
\hline \multicolumn{4}{|c|}{45 AÑOS O MÁS } \\
\hline 1 & $\mathrm{~T} 1$ & NO & MO \\
\hline II & $\mathrm{T} 2$ & NO & MO \\
\hline \multirow[t]{4}{*}{ III } & T3 & NO & M0 \\
\hline & $\mathrm{T} 1$ & $\mathrm{~N} 1 \mathrm{a}$ & MO \\
\hline & $\mathrm{T} 2$ & $\mathrm{~N} 1 \mathrm{a}$ & Mo \\
\hline & T3 & $\mathrm{N} 1 \mathrm{a}$ & Mo \\
\hline \multirow[t]{6}{*}{ IVA } & T4a & NO & MO \\
\hline & T4a & $\mathrm{N} 1 \mathrm{a}$ & M0 \\
\hline & $\mathrm{T} 1$ & N1b & MO \\
\hline & $\mathrm{T} 2$ & N1b & MO \\
\hline & T3 & $\mathrm{N} 1 \mathrm{~b}$ & Mo \\
\hline & T4a & $\mathrm{N} 1 \mathrm{~b}$ & MO \\
\hline IVB & $\mathrm{T} 4 \mathrm{~b}$ & Cualquier N & Mo \\
\hline Estadio IVC & Cualquier $\mathrm{T}$ & Cualquier $\mathrm{N}$ & M1 \\
\hline
\end{tabular}

Tabla 3 - Estadificación TNM (93) 


\begin{tabular}{|c|c|c|c|}
\hline \multicolumn{4}{|c|}{ Riesgo de recurrencia en pacientes con cáncer diferenciado de tiroides } \\
\hline Muy Bajo Riesgo & Bajo Riesgo & Riesgo Intermedio & Alto Riesgo \\
\hline $\begin{array}{l}- \text { Tumor } \leq 1 \mathrm{~cm} \text { unifocal } \\
\text { (T1a) }\end{array}$ & $\begin{array}{l}- \text { Tumor } \leq 1 \mathrm{~cm} \text { multifocal } \\
\left(\mathrm{T} 1 \mathrm{a}_{\mathrm{m}}\right) \\
\text {-Tumor intratiroideo entre } 1 \\
y 4 \mathrm{~cm} \\
(\mathrm{~T} 1 \mathrm{~b}-\mathrm{T} 2)\end{array}$ & $\begin{array}{l}\text { Tumor }>4 \mathrm{~cm} \\
(\text { T } 3>4 \mathrm{~cm})\end{array}$ & $\begin{array}{l}\text { - Tumor con extensa } \\
\text { invasión extratiroidea } \\
\text { (T4) } \\
\text { - Resección tumoral incom- } \\
\text { pleta }\end{array}$ \\
\hline - Sin invasión capsular & $\begin{array}{l}\text {-Ausencia de extensión extra- } \\
\text { capsular o minima extensión } \\
\text { en tumores }<4 \mathrm{~cm} \\
(\mathrm{~T} 3<4 \mathrm{~cm})\end{array}$ & & \\
\hline $\begin{array}{l}\text {-Sin histología agresiva } \\
\text { (carcinoma papilar clásico } \\
\text { o papilar variedad folicular) }\end{array}$ & $\begin{array}{l}\text {-Sin histologia agresiva } \\
\text { (carcinoma papilar clásico o } \\
\text { papilar variedad folicular) }\end{array}$ & $\begin{array}{l}\text {-Histología agresiva } \\
\text { (papilar de células altas, } \\
\text { papilar de células colum- } \\
\text { nares, esclerosante difuso, } \\
\text { carcinoma de células de } \\
\text { Hürthle) }\end{array}$ & \\
\hline $\begin{array}{l}\text { Carcinoma folicular míni- } \\
\text { mamente invasivo } \leq 1 \mathrm{~cm}\end{array}$ & $\begin{array}{l}\text {-Carcinoma folicular mini- } \\
\text { mamente invasivo }>1 \mathrm{~cm} \\
\text { intratiroideo }\end{array}$ & & $\begin{array}{l}\text {-Carcinoma folicular amplia- } \\
\text { mente invasivo }\end{array}$ \\
\hline -Sin invasión vascular & -Sin invasión vascular & -Invasión vascular & \\
\hline $\begin{array}{l}\text {-NO clínico, y/o por anato- } \\
\text { mía patológica* }\end{array}$ & $\begin{array}{l}\text {-NO clínico o micrometástasis } \\
(<0,2 \mathrm{~cm}) \text { o } \\
\text { pN1 } 5 \text { ganglios con MTS < } \\
1 \mathrm{~cm} .\end{array}$ & $\begin{array}{l}-N 1 \text { clínico o } \\
\text { pN1 }>5 \text { ganglios con MTS } \\
\text { (entre } 0,2-1 \mathrm{~cm}) \circ \\
\text { al menos ganglio con me- } \\
\text { tástasis }>1 \mathrm{~cm} . .\end{array}$ & $\begin{array}{l}-p N 1 \text { con > } 3 \text { ganglios con } \\
\text { extensión extracapsular " }\end{array}$ \\
\hline -Mo clínico & - Mo clínico & -Mo clínico & $-M 1$ \\
\hline
\end{tabular}

Tabla 4 - Estratificación de riesgo de recurrencia, según factores patológicos (tomado de 1) 


\begin{tabular}{|l|l|l|}
\hline & Factor clínico (edad) & Factor patológico \\
\hline Muy Bajo Riego & Buen pronóstico (menor 45 años) & Muy Bajo Riesgo (papilar) \\
\hline Bajo riesgo & Buen pronóstico (menor 45 años) & $\begin{array}{l}\text { Muy Bajo Riesgo (folicular) - } \\
\text { Bajo riesgo }\end{array}$ \\
\hline Riesgo Intermedio & $\begin{array}{l}\text { Buen pronóstico (menor 45 años) } \\
\text { Pronóstico Desfavorable (mayor de 45 años) }\end{array}$ & $\begin{array}{l}\text { Riesgo Intermedio - Alto } \\
\text { Riesgo Bajo - Intermedio }\end{array}$ \\
\hline Alto Riesgo & Pronóstico Desfavorable (mayor de 45 años) & Riesgo Intermedio - Alto \\
\hline
\end{tabular}

Tabla 5 - Estratificación de grupos de riesgo (modificado de 94) 


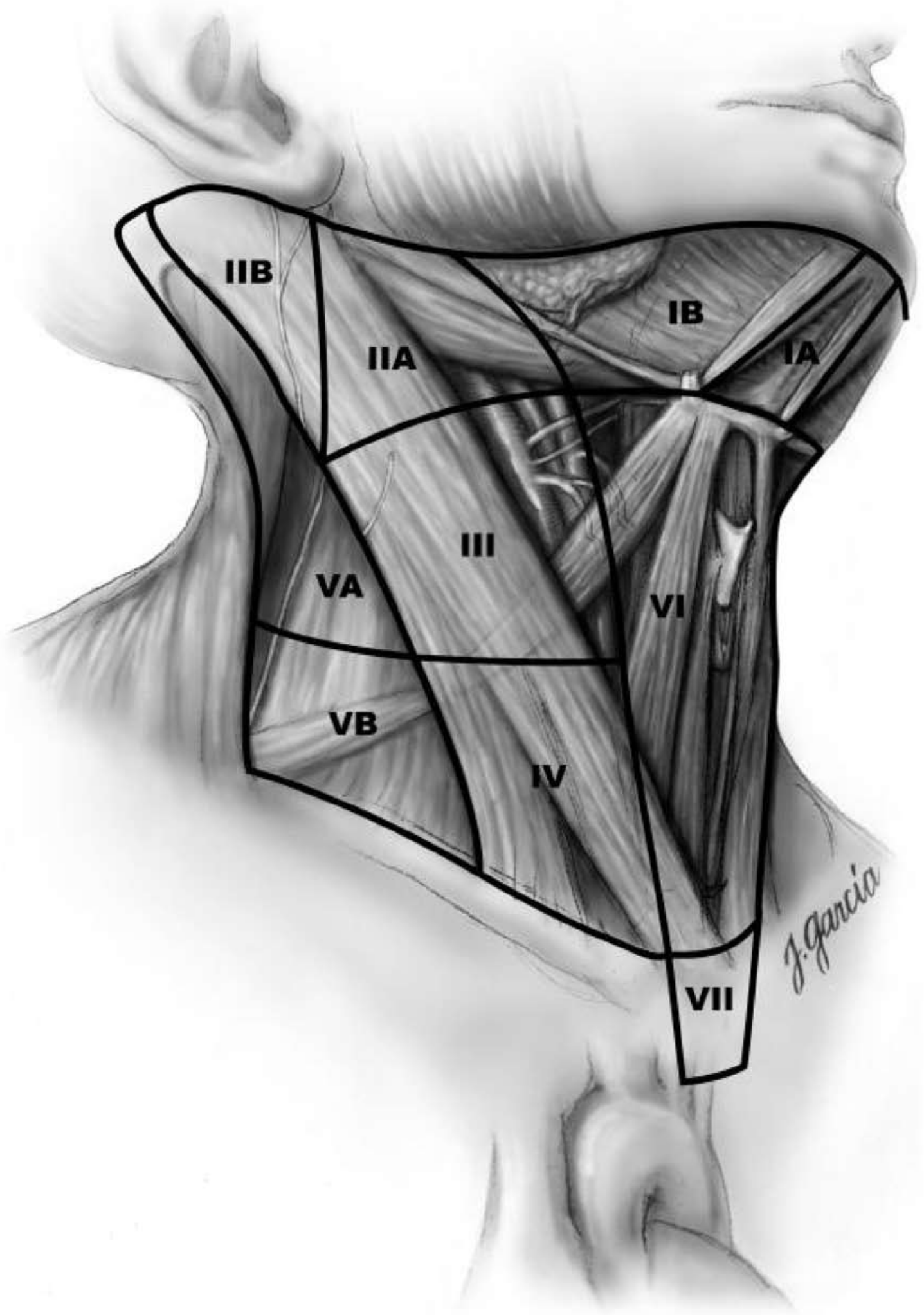

Figura 1 - Grupos ganglionares cervicales (tomado 149). 


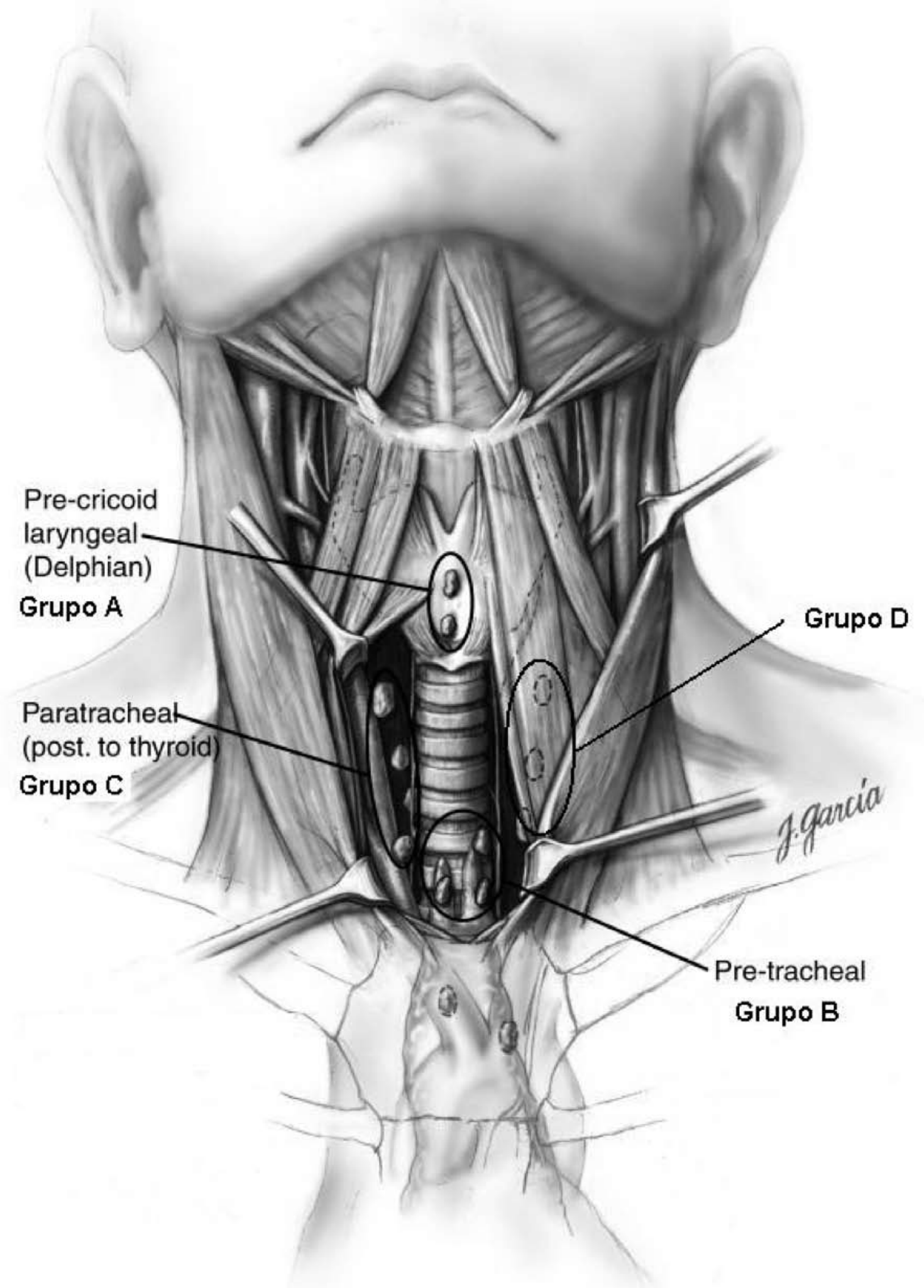

Figura 2 - Subgrupos del grupo VI (tomado y modificado de 149). 


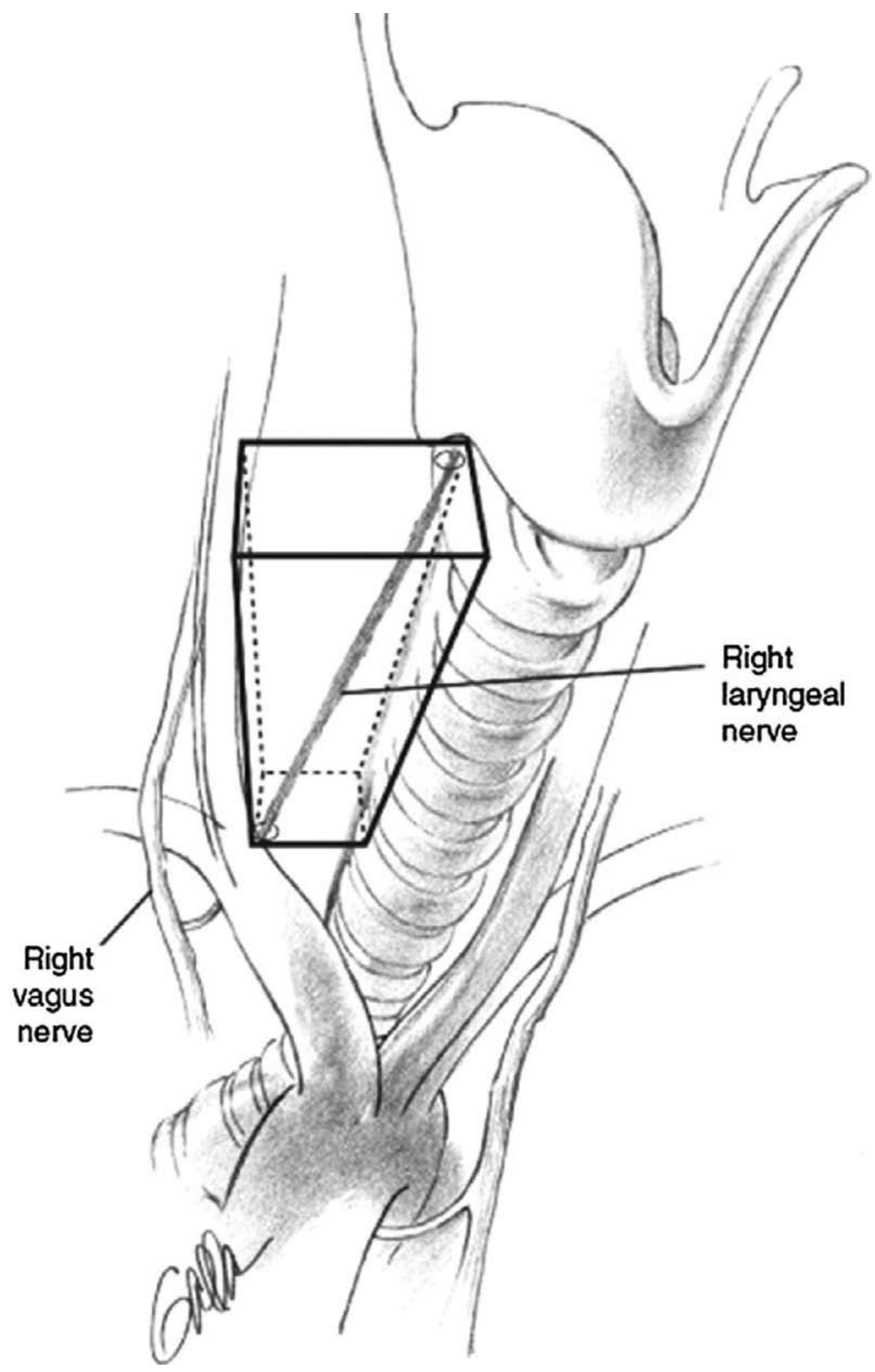

Figura 3 - Grupo VI, subgrupo C - recurrenciales derechos (tomado de 155). 


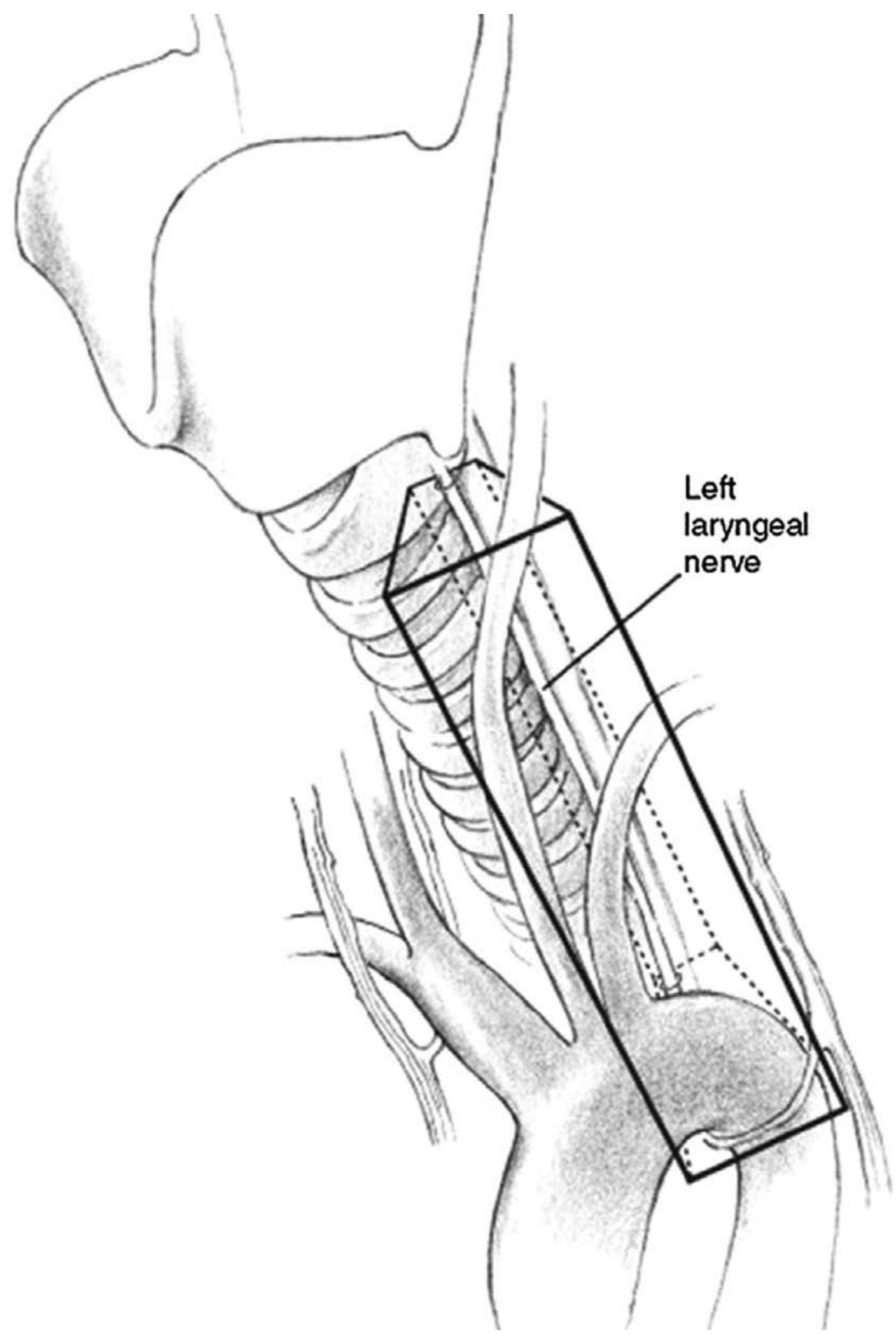

Figura 4 - Grupo VI, subgrupo D - recurrenciales izquierdos. (tomado de 155). 
